FLAVIA REGINA OLIVEIRA DE BARROS

\title{
Modificação de células-tronco espermatogoniais para produção de bovinos transgênicos
}

São Paulo

2012 


\section{FLAVIA REGINA OLIVEIRA DE BARROS}

\section{Modificação de células-tronco espermatogoniais para produção de bovinos transgênicos}

Tese apresentada ao Programa de PósGraduação em Reprodução Animal da Faculdade de Medicina Veterinária e Zootecnia da Universidade de São Paulo para obtenção do título de Doutor em Ciências

Departamento:

Reprodução Animal

Área de Concentração:

Reprodução Animal

Orientador:

Prof. Dr. José Antônio Visintin

São Paulo

2012 
Autorizo a reprodução parcial ou total desta obra, para fins acadêmicos, desde que citada a fonte.

DADOS INTERNACIONAIS DE CATALOGAÇÃO-NA-PUBLICAÇÃO

(Biblioteca Virginie Buff D’Ápice da Faculdade de Medicina Veterinária e Zootecnia da Universidade de São Paulo)

Barros, Flavia Regina Oliveira de Modificação de células-tronco espermatogoniais para produção de bovinos transgênicos / Flavia Regina Oliveira de Barros. -- 2012. $129 \mathrm{f}$. : il.

Tese (Doutorado) - Universidade de São Paulo. Faculdade de Medicina Veterinária e Zootecnia. Departamento de Reprodução Animal, São Paulo, 2012.

Programa de Pós-Graduação: Reprodução Animal.

Área de concentração: Reprodução Animal.

Orientador: Prof. Dr. José Antônio Visintin.

1. Células-tronco espermatogoniais. 2. Bovinos. 3. Transgenia Animal. I. Título. 


\section{FACULDADE DE MEDICINA VETERINÁRIA E ZOOTECNIA}

\section{CERTIFICADO}

Certificamos que o Projeto intitulado "Modificação de células-tronco espermatogoniais para produção de bovinos transgênicos", protocolado sob o ${ }^{\circ}$ 1695/2009, utilizando 15 (quinze) bovinos, sob a responsabilidade do Prof. Dr. José Antonio Visintin, está de acordo com os princípios éticos de experimentação animal da Comissão de Bioética da Faculdade de Medicina Veterinária e Zootecnia da Universidade de São Paulo e foi aprovado em reunião de 19 de agosto de 2009.

We certify that the Research "Modification of spermatogonial stem cells to produce transgenic bovine", protocol number 1695/2009, utilizing 15 (fifteen) bovines, under the responsibility Prof. Dr. José Antonio Visintin, agree with Ethical Principles in 'Animal Research adopted by Bioethic Commission of the School of Veterinary Medicine and Animal Science of University of São Paulo and was approved in the meeting of day 08/19/09.

São Paulo, 24 de agosto de 2009

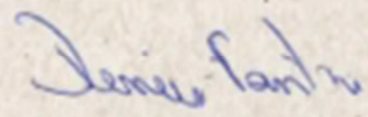

Profa Dra Denise Tabacchi Fantoni

Presidente da Comissão de Bioética FMVZ/USP 


\section{FOLHA DE AVALIAÇÃO}

Nome: BARROS, Flavia Regina Oliveira de

Título: Modificação de células-tronco espermatogoniais para produção de bovinos transgênicos

Tese apresentada ao Programa de Pós-Graduação em Reprodução Animal da Faculdade de Medicina Veterinária e Zootecnia da Universidade de São Paulo para obtenção do título de Doutor em Ciências

Data:

\section{Banca Examinadora}

Prof. Dr.

Instituição: Julgamento:

Prof. Dr.

Instituição: Julgamento:

Prof. Dr.

Instituição: Julgamento:

Prof. Dr.

Instituição: Julgamento:

Prof. Dr. Instituição: Julgamento: 
Às minhas duas mães, Carmen e Claryce.

Ao Dan. 
"Glory lies in the attempt to reach one's goal and not in reaching it."

(Gandhi) 


\section{Agradecimentos}

Depois de 38 meses de doutorado, não me permito dizer ser muito difícil colocar no papel minhas ideias sobre células-tronco, transgenia animal ou biotecnologia. Difícil sim é conseguir expressar de maneira justa minha gratidão a todos que participaram deste trabalho, direta ou indiretamente, e contribuíram para a realização de um projeto, escrito em papel, há 38 meses e sua transformação em tese.

Tive a ideia de fazê-lo graficamente. Mas como organizar todos os agradecimentos, utilizando um esquema, uma figura, um desenho, um gráfico, uma imagem, e ainda embutir o significado e a importância de cada um? Eu precisava de um símbolo. Eu procurei símbolos que pudessem expressar como eu vi tudo. Como eu vejo a todos. Como eu senti tudo. Como eu sinto.

Eis o que obtive... 


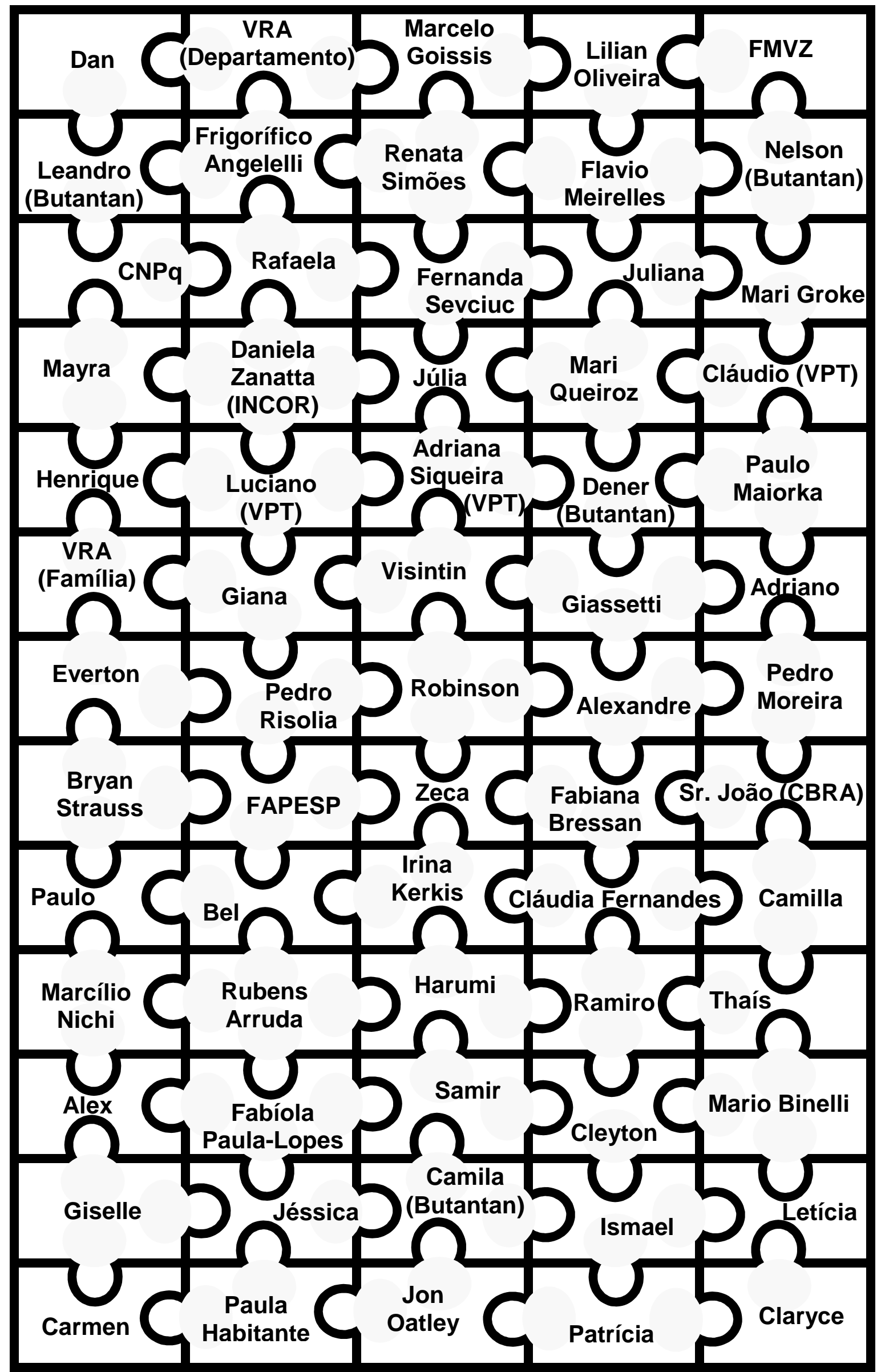


Quando montamos um quebra-cabeças, cada peça é única e insubstituível. Cada um de vocês representa uma peça importante na realização deste trabalho, na elaboração desta tese. Agradeço a todos pela participação, por acreditar em mim, pela ajuda, apoio financeiro, discussões científicas, chocolates, paciência, sorrisos, abraços, compreensão, amizade. Eu olho para trás agora e tenho uma certeza. Com vocês, eu faria tudo de novo.

Obrigada!

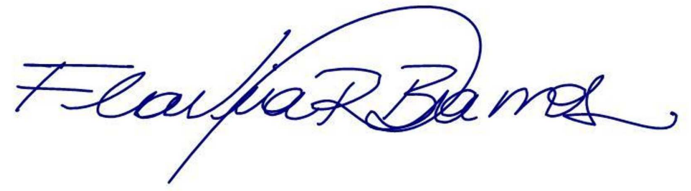

09/04/2012 


\section{RESUMO}

BARROS, F. R. O. de. Modificação de células-tronco espermatogoniais para produção de bovinos transgênicos. [Modification of spermatogonial stem cells to produce transgenic bovine]. 2012. 129 f. Tese (Doutorado em Ciências) - Faculdade de Medicina Veterinária e Zootecnia, Universidade de São Paulo, São Paulo, 2012.

A espermatogênese em mamíferos é um processo sustentado pela auto-renovação e diferenciação de células-tronco espermatogoniais (SSCs). O estudo destas células oferece um excelente modelo para o melhor entendimento da biologia das célulastronco adultas e dos mecanismos que controlam as funções das SSCs. Além do potencial biomédico para estudos sobre infertilidade em diferentes espécies, as SSC possuem uma aplicação promissora na biotecnologia para a produção de animais transgênicos. Assim, o objetivo deste trabalho foi responder à pergunta: "SSCs bovinas LacZ+ podem integrar-se aos túbulos seminíferos de bezerros pré-púberes da raça Nelore após transplante autólogo?" Para isso, bezerros Nelore de 5 meses de idade $(n=16)$ foram submetidos a uma orquiectomia unilateral para 0 isolamento de células espermatogoniais por digestão enzimática. Após o plaqueamento diferencial, as células foram transduzidas com um vetor lentiviral contendo a sequencia do gene marcador LacZ. Para isso, os animais foram aleatoriamente alocados em um dos quatro grupos experimentais: LacZ+/PKH26+, LacZ+/PKH26-, LacZ-/PKH26+, LacZ-/PKH26-. Após 60 h do início do cultivo in vitro, as células espermatogoniais foram transplantadas autologamente para o mediastino do testículo remanescente por injeção guiada por ultrassonografia. O testículo transplantado foi removido cirurgicamente após 45 dias e amostras de tecido foram submetidas a reação com x-gal para verificação da integração de células espermatogoniais transgênicas aos túbulos seminíferos. Células espermatogoniais foram isoladas e cultivadas in vitro com sucesso. Contudo, não foi possível obter uma população pura de SSCs por plaqueamento diferencial. Embora tenha sido eleito o transplante de células espermatogoniais e não de SSCs somente, sabe-se que também foram transplantadas SSCs, pois a caracterização das células isoladas demonstrou a expressão dos marcadores de SSCs ITGA6, GFRa-1, PGP 9.5 e afinidade pela lectina DBA. Crioseções de amostras de tecido testicular coradas com x-gal permitiram a observação de células transgênicas em 8 de 8 animais que receberam células LacZ+. Contudo, todas as células transgênicas observadas estavam situadas no interstício. Concluindo, não foi possível observar a integração 
das células transgênicas transplantadas aos túbulos seminíferos do testículo receptor após 45 dias do transplante autólogo utilizando a técnica de injeção intratesticular de células espermatogoniais LacZ+ no mediastino de bezerros prépúberes da raça Nelore.

Palavras-chave: Células-tronco espermatogoniais. Bovinos. Transgenia Animal. 


\section{ABSTRACT}

BARROS, F. R. O. de. Modification of spermatogonial stem cells to produce transgenic bovine. [Modificação de células-tronco espermatogoniais para produção de bovinos transgênicos]. 2012. 129 f. Tese (Doutorado em Ciências) - Faculdade de Medicina Veterinária e Zootecnia, Universidade de São Paulo, São Paulo, 2012.

Mammalian spermatogenesis is sustained by self renewal and differentiation of spermatogonial stem cells (SSCs). The study of these cells provides a model to better understand adult stem cell biology and the mechanisms that control SSC functions. Besides the biomedical potential to perform studies of infertility in many species, SSCs hold a promising biotechnological application at animal transgenesis. In this manner, the goal of this study was to answer the question: "Can LacZ+ bovine SSCs be integrated into seminiferous tubule of prepubertal Nelore bulls subjected to autologous transplantation?" Hence, 5 months old bulls $(n=16)$ were hemicastrated and spermatogonial cells were isolated by a two step enzymatic digestion procedure. After differential plating, cells were transduced with a lentivirus vector carrying the LacZ reporter gene sequence. Animals were randomly allocated in four experimental groups: LacZ+/PKH26+, LacZ+/PKH26-, LacZ-/PKH26+, LacZ-/PKH26-. After 60 h of the onset of in vitro culture, spermatogonial cells were autologously transplanted to the remaining testes by an ultrasound guided needle injection at the testis mediastinum. The transplanted testes were surgically removed after 45 days and testicular tissue samples were subjected to $\mathrm{x}$-gal staining to assess the integration of transgenic spermatogonial cells to seminiferous tubule. Spermatogonial cells were successfully isolated and in vitro cultured. However, it was not possible to obtain a SSC enriched population of cells by differential plating. Although it was decided by the transplant of spermatogonial cells instead of pure SSCs only, it was detected the expression of SSC marker genes ITGA6, PGP9.5, GFRa-1 and the affinity for DBA by the isolated cells. Cryosections of $x$-gal stained testicular tissue samples allowed the observation of transgenic cells in 8 out of 8 animals that received LacZ+ cells. However, all transgenic cells observed were located at the interstitial space. In conclusion, it was not possible to observe the integration of the transplanted transgenic cells into seminiferous tubule of prepubertal Nelore bulls subjected to autologous transplantation using an ultrasound guided needle injection at the testis mediastinum, after 45 days of transplant.

Keywords: Spermatogonial stem cells. Bovine. Animal Transgenesis. 


\section{LISTA DE FIGURAS}

Figura 1 - Figura esquemática dos possíveis destinos das SSCs na divisão celular durante a fase de proliferação da espermatogênese em mamíferos. Fonte: adaptado de OATLEY, J. M.; BRINSTER (2008). 34

Figura 2 - Figura esquemática dos possíveis tipos de divisão celular das SSCs durante fase de proliferação da espermatogênese em mamíferos. Fonte: adaptado de OATLEY, J. M.; BRINSTER (2008). 36

Figura 3 - Fotografia do tubo cônico de centrifuga de $50 \mathrm{~mL}$ contendo o gradiente descontínuo de Percoll com camadas de 1,0413 (20\%), 1,0513 (28\%), 1,0542 (30\%) e 1,0611 (36\%) g/mL de Percoll em DMEM ou PBS. Frações 1-4: regiões de onde foram recuperadas células após a centrifugação. São Paulo, 2011.

Figura 4 - Fotografia representativa de células espermatogoniais bovinas após o isolamento enzimático obtida por microscopia óptica (Magnificação de $200 \mathrm{x}$ ). Células espermatogoniais de diferentes tamanhos (setas vermelhas) e espermatozoides (setas pretas).

Figura 5 - Gráfico das porcentagem de células espermatogoniais expressando alfa-6 integrina, analisadas por citometria de fluxo, antes (Fração 0) e depois da purificação com gradiente descontínuo de Percoll (Frações 1-4; Média dos quadrados mínimos + EPM). 61

Figura 6 - Gráfico da expressão de alfa-6 integrina em células espermatogoniais. Histogramas ilustrativos de florescência verde (alfa-6 integrina; preto) 
contra fluorescência vermelha ( $\mathrm{Pl}$; cinza) antes (F0) e depois da purificação com gradiente de Percoll (F1-F4).

Figura 7 - Gráfico da expressão de alfa-6 integrina em células espermatogoniais bovinas avaliadas por citometria de fluxo. Eixo y: fluorescência verde (FITC) e eixo $\mathrm{x}$ : tamanho celular. Em (A) observa-se uma amostra positiva para expressão de alfa-6 integrina e em (B), o controle negativo da reação

Figura 8 - Gráfico da afinidade das células espermatogoniais bovinas pela lectina DBA avaliadas por citometria de fluxo. Eixo y: fluorescência verde (FITC) e eixo $\mathrm{x}$ : tamanho celular. Em (A) observa-se uma amostra positiva para marcação com DBA e em (B), o controle negativo da reação. 63

Figura 9 - Fotografia da reação de imunocitoquímica de células espermatogoniais bovinas para verificação da expressão de PGP9.5. (A) Núcleo celular marcado com Hoechst 33342, (B) células positivas para expressão de PGP9.5 (verde, FITC) e (C) sobreposição das imagens A e B (magnificação de $200 \mathrm{x}$ ). 64

Figura 10 - Gráfico da expressão relativa dos genes ITGA6, GFRa-1 e PGP9.5 em células espermatogoniais de bovinos adultos avaliado por reação de RT-PCR em tempo real. 65

Figura 11 - Fotografia de microscopia de epifluorescência com filtro para rodamina de células espermatogoniais após incubação com PKH26 (200x).......66

Figura 12 - Fotografia de (A) células espermatogoniais bovinas adultas expressando beta-galactosidase após transdução com o vetor lentiviral pLV-Lacz e (B) controle negativo (magnificação de $400 \mathrm{x}$ ). 
Figura 13 - Fotografia de testículos bovinos obtidos em abatedouro comercial após injeção de $5 \mathrm{~mL}$ do corante azul de tripan guiada por ultrassonografia. Em (A) observa-se a distribuição do corante no mediastino e em (B) o confinamento do corante em um único ponto. 68

Figura 14 - Delineamento experimental fatorial 2x2 (SSCs transduzidas ou não com LacZ, marcadas ou não com o corante PKH26) para o estudo da integração de SSCs bovinas LacZ+ após transplante autólogo. .75

Figura 15 - Coleta de tecido de testículos de bezerros pré-púberes para isolamento de células espermatogoniais. (A) Incisão da túnica albugínea e (B) dissecção do parênquima testicular.

Figura 16 - Seringas contendo $1 \times 10^{6}$ células espermatogoniais em PBS, mantidas a $37^{\circ} \mathrm{C}, 5 \% \mathrm{CO}_{2}$ em ar com alta umidade até o momento do transplante. Os números correspondem ao número do brinco do animal ao qual pertencem as células.

Figura 17 - Imagens ultrassonográficas do acompanhamento do transplante autólogo de células espermatogoniais em bezerros pré-púberes. (A, C, D) Imagens obtidas antes da injeção, demonstrando o parênquima testicular anecogênico. (B, D, F) Imagens obtidas após injeção, demonstrando conteúdo líquido injetado hiperecogênico, indicado por setas vermelhas.

Figura 18 - Fotografias da coleta de amostras do testículo transplantado com células espermatogoniais. Em (A) testículo dissecado da túnica albugínea e (B) testículo divido em três seções: cranial (SCr), central (SC) e caudal (SCa). 
Figura 19 - Fotografia microscopia óptica de luz de células espermatogoniais de bezerros pré-púberes cultivadas in vitro. Imagem obtida após plaqueamento diferencial (D1) (Magnificação de 400 x).

Figura 20 - Fotografias de crioseções de amostras de testículos transplantados com células espermatogoniais LacZ+, removidos cirurgicamente após 45 dias do transplante autólogo. O tecido foi submetido à reação enzimática com o corante $x$-gal para visualização das células transgênicas, em azul (setas vermelhas). Microscopia de luz (Magnificação de 400x). 96 e 97

Figura 21 - Fotografias de microscopia de epifluorescência de células espermatogoniais isoladas de bezerros pré-púberes da raça Nelore submetidas à detecção da expressão do marcador PGP9.5 por reação de imunofluorescência. (A) Núcleos celulares marcados com Hoechst (azul), (B) Células marcadas com anticorpo anti-PGP9.5 e anticorpo secundário conjugado ao fluoróforo FITC (verde), (C) Sobreposição das imagens A e B (Magnificação de 400 x).

Figura 22 - Fotografias de microscopia de epifluorescência de células espermatogoniais isoladas de bezerros pré-púberes da raça Nelore com afinidade por DBA (A) Núcleos celulares marcados com Hoechst (azul), (B) Células marcadas com anticorpo anti-PGP9.5 e anticorpo secundário conjugado ao fluoróforo FITC (verde), (C) Sobreposição das imagens A e B (Magnificação de 400 x). 100

Figura 23 - Fotografias de microscopia de epifluorescência de células espermatogoniais isoladas de bezerros pré-púberes da raça Nelore submetidas à detecção da expressão do marcador PGP9.5 por reação de imunofluorescência. (A) Núcleos celulares marcados com Hoechst (azul), (B) Células marcadas com anticorpo anti-alfa-6 integrina 
conjugado ao fluoróforo FITC (verde), (C) Sobreposição das imagens A e B (Magnificação de 400 x)..........................................................101

Figura 24 - Expressão relativa dos genes ITGA6, GFR-1 e PGP9.5 em células espermatogoniais de bovinos adultos avaliado por reação de RT-PCR em tempo real. 102

Figura 25 - Fotografia de corte histológico submetido à reação de imunohistoquímica para verificação da expressão do marcador de SSCs, PGP9.5, em amostras obtidas de testículos doadores de células espermatogoniais. Células marcadas em marrom representam células positivas para expressão de PGP9.5. Contra-coloração em azul realizada com hematoxilina de Harris para marcação dos núcleos celulares (Magnificação de 400x).....................................................104

Figura 26 - Fotografias de microscopia de epifluorescência de amostras do testículo doador de células espermatogoniais de bezerros pré-púberes da raça Nelore submetidas à incubação com DBA conjugada ao FITC. (A) Núcleos celulares marcados com Hoechst (azul), (B) Células marcadas com DBA (verde), (C) Sobreposição das imagens A e B (Magnificação de $400 \mathrm{x})$. 105 


\section{LISTA DE QUADROS}

Quadro 1 - Primers utilizados na verificação da expressão dos genes alvo ITGA6, GFRa-1, PGP9.5 e como controles endógenos ACTB e GAPDH..........53

Quadro 2 - Resumo das manipulações realizadas para isolamento de SSC bovinas.

Quadro 3 - Porcentagem de células marcadas com PKH26 analisadas por citometria de fluxo. .66

Quadro 4 - Lista de técnicas utilizadas para a verificação da integração de células espermatogoniais após transplante autólogo. .84 


\section{LISTA DE TABELAS}

Tabela 1 - Expressão relativa de ITGA6, GFRa-1 e PGP9.5 em células espermatogoniais antes (D0) e depois do plaquamento diferencial (D1).

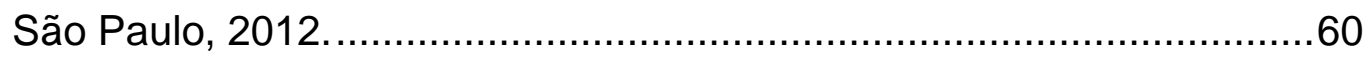

Tabela 2 - Comparação da expressão de ITGA6 entre amostra coletadas antes (F0) e depois da purificação com gradiente descontínuo de Percoll (F1-4) avaliada por RT-PCR em tempo real. São Paulo, 2012.

Tabela 3 - Médias das porcentagens de células viáveis (LSM + SEM) de células espermatogoniais dos 4 lotes de bezerros pré-púberes da raça Nelore após 12-16 h de cultivo in vitro (D1). (São Paulo, 2012).

Tabela 4 - Médias das massas (LSM + SEM) de tecido dissecado dos testículos receptores 45 dias após transplante autólogo com células espermatogoniais de bezerros pré-púberes da raça Nelore (São Paulo, 2012). .95 


\section{LISTA DE ABREVIATURAS E SIGLAS}

\begin{tabular}{|c|c|}
\hline$A_{1-4}$ & Célula-tronco espermatogonial do tipo A (1-4) \\
\hline$A_{a l}$ & Célula-tronco espermatogonial do tipo A alinhada \\
\hline ACTB & Beta actina (gene) \\
\hline$A_{\text {escura }}$ & Célula-tronco espermatogonial do tipo A escura \\
\hline A pálida & Célula-tronco espermatogonial do tipo A pálida \\
\hline$A_{p r}$ & Célula-tronco espermatogonial do tipo A pareada \\
\hline$A_{s}$ & Célula-tronco espermatogonial do tipo A simples \\
\hline ASPC & $\begin{array}{l}\text { Células precursoras de espermatogônias agregadas, do inglês } \\
\text { aggregated spermatogonial precursor cells }\end{array}$ \\
\hline $\mathrm{B}_{1}-\mathrm{B}_{4}$ & Célula-tronco espermatogonial do tipo B (1-4) \\
\hline BEF & $\begin{array}{l}\text { Fibroblastos fetais bovines, do inglês bovine embryonic } \\
\text { fibroblasts }\end{array}$ \\
\hline BSA & Albumina sérica bovina, do inglês bovine serum albumin \\
\hline BSC & $\begin{array}{l}\text { Células-tronco espermatogoniais basais, do inglês basal } \\
\text { spermatogonial cells }\end{array}$ \\
\hline cDNA & $\begin{array}{l}\text { Ácido desoxiribonucléico complementar, do inglês } \\
\text { complementary deoxyribonucleic acid }\end{array}$ \\
\hline CMV & Citomegalovírus, do inglês cytomegalovirus \\
\hline cPPT & Central polypurine tract \\
\hline CSPC & $\begin{array}{l}\text { Células precursoras de espermatogônias comprometidas, do } \\
\text { inglês committed spermatogonial precursor cells }\end{array}$ \\
\hline DBA & $\underline{\text { Dolichus biflorus agglutinin }}$ \\
\hline DEPC & Dietilpirocarbonato, do inglês diethylpyrocarbonate \\
\hline DMEM & Dulbecco's Modified Eagle Medium \\
\hline DNA & Ácido desoxirribonucleico, do inglês deoxyribonucleic acid \\
\hline ECM & Matrix extracellular, do ingles extracellular matrix \\
\hline FACS & $\begin{array}{l}\text { Separação celular ativada por fluorescência, do inglês } \\
\text { fluorescence-activated cell sorting }\end{array}$ \\
\hline FITC & $\begin{array}{l}\text { Isotiocianato de fluoresceína, do inglês fluorescein } \\
\text { isothiocyanate }\end{array}$ \\
\hline
\end{tabular}


3-phosphate dehydrogenase

GDNF Fator neurotrófico derivado da glia, do inglês glial cell linederived neurotrophic factor

LacZ+ $\quad$ Expressão positiva do gene LacZ

GFRa-1 Receptor alfa-1 da família GDNF, do inglês glial cell line-derived neurotrophic factor receptor alpha 1

HBSS Hank's salt solution

ITGA6 Alfa-6 integrina (gene)

MACS Separação celular ativada magneticamente, do inglês magneticactivated cell sorting

MEF Fibroblastos fetais murinos, do inglês murine embryonic fibroblasts

MOI Multiplicidade de infecção, do inglês multiplicity of infection

PBS Solução tampão de fosfato, do inglês phosphate buffer solution

PGC Células germinativas primordiais, do inglês primordial germ cells

PGP9.5 Ubiquitina hidrolase C-terminal L1

PI lodeto de propídio, do inglês propidium iodide

PKH26 Corante de rastreamento celular PKH26

RNA Ácido ribonucleico, do inglês ribonucleic acid

FCS Soro fetal bovino, do inglês fetal calf serum

SFFV spleen focus-forming virus

SIN-LTR self-inactivating long terminal repeat

SMGT Transferência gênica mediada por espermatozoides, do inglês Sperm mediated gene transfer

SSC Célula-tronco espermatogonial, do inglês spermatogonial stem cell

SSCs Células-tronco espermatogoniais, do inglês spermatogonial stem cells

STRA8 stimulated by retinoic acid gene 8

U6 Região regulatória

UCHL1 Ubiquitina hidrolase C-terminal L1

wPRE Woodchuck hepatitis virus post-transcriptional regulatory element 


\section{LISTA DE SÍMBOLOS}

$\begin{array}{ll}\beta & \text { Beta } \\ \mathrm{xg} & \text { Força de centrifugação em g (gravidade) } \\ \mathrm{g} & \text { Grama (s) } \\ { }^{\circ} \mathrm{C} & \text { Graus Celsius } \\ \mathrm{h} & \text { Hora (s) } \\ + & \text { Mais } \\ { }^{\circledR} & \text { Marca Registrada } \\ < & \text { Menor } \\ \mu & \text { Micro } \\ \mathrm{mL} & \text { Mililitro (s) } \\ \mathrm{mm} & \text { Milímetro (s) } \\ \mathrm{mM} & \text { Milimolar (es) } \\ \mathrm{min} & \text { Minuto (s) } \\ \% & \text { Porcentagem } \\ (\mathrm{v} / \mathrm{v}) & \text { Razão entre dois volumes (dada em porcentagem) } \\ (\mathrm{m} / \mathrm{v}) & \text { Razão entre massa e volume (dada em porcentagem) } \\ \mathrm{s} & \text { Segundo (s) }\end{array}$


1 INTRODUÇÃO

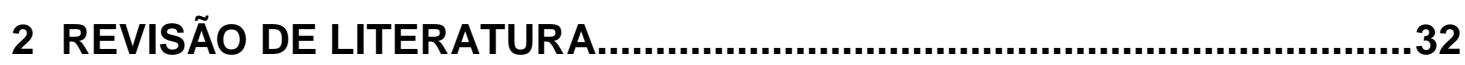

2.1 CÉLULAS-TRONCO ESPERMATOGONIAIS ….......................................32

2.1.1 Definição e função das SSCs na espermatogênese ..........................32

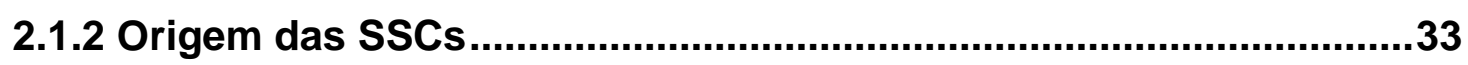

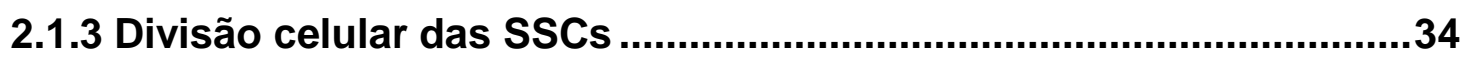

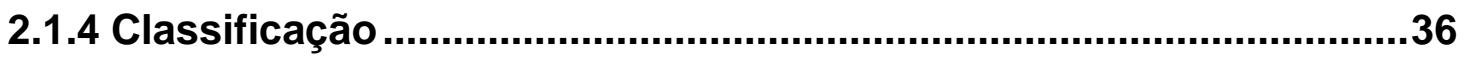

2.2 CARACTERIZAÇÃO DE CÉLULAS-TRONCO ESPERMATOGONIAIS ..37 2.3 ISOLAMENTO E CULTIVO IN VITRO DE CÉLULAS-TRONCO

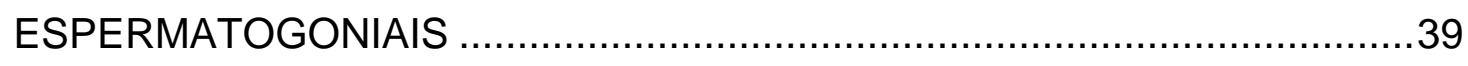

2.4 CÉLULAS-TRONCO ESPERMATOGONIAIS E SUAS APLICAÇÕES ....42

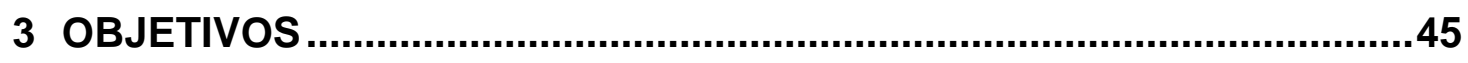

4 CAPÍtULO 1: ISOLAMENTO DE CÉLULAS ESPERMATOGONIAIS

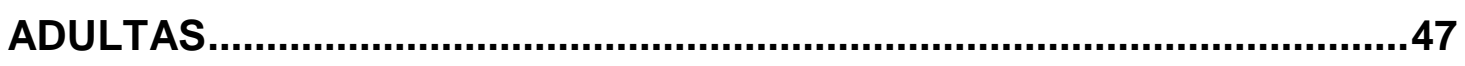

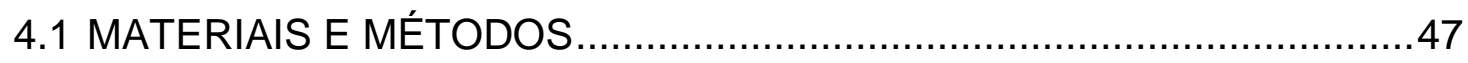

4.1.1 Isolamento de células espermatogoniais de bovinos adultos.........47

4.1.2 Purificação das SSCs de bovinos adultos ......................................48

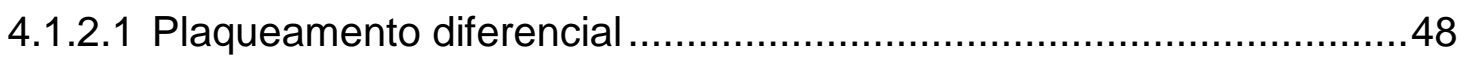

4.1.2.2 Gradiente descontínuo de Percoll ..................................................48

4.1.3 Caracterização das células espermatogoniais de bovinos adultos

4.1.3.1 Detecção da expressão de alfa-6 integrina e afinidade pela lectina DBA por citometria de Fluxo. .50

4.1.3.2 Deteção da expressão de PGP9.5 por reação de imunofluorescência em células espermatogoniais de bovinos adultos

4.1.3.3 Expressão gênica dos marcadores ITGA6, GFRa-1 e PGP9.6 em células espermatogoniais de bovinos adultos .52 
4.1.4 Marcação das células espermatogoniais de bovinos adultos com PKH26

4.1.5 Transformação das células espermatogoniais de bovinos adultos .54

4.1.6 Injeção de corante azul de tripan em testículos de bovinos adultos .55

4.1.7 Verificação da expressão de alfa-6 integrina antes e após purificação por gradiente de percoll. .56

4.1.8 Estudo do perfil de expressão dos genes itga6, gfr-1 e pgp9.5 em células espermatogoniais antes e após plaqueamento diferencial .57

4.2 RESULTADOS 58

4.2.1 Isolamento de células espermatogoniais de bovinos adultos.........58

4.2.2 Purificação das SSCs de bovinos adultos.........................................59

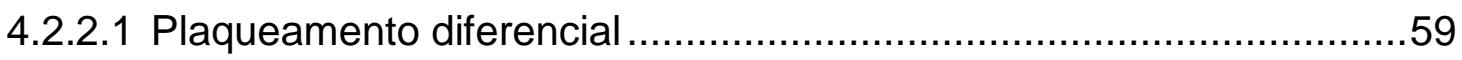

4.2.2.2 Gradiente descontínuo de Percoll .................................................60

4.2.3 Caracterização das células espermatogoniais de bovinos adultos 62

4.2.3.1 Detecção da expressão de alfa-6 integrina e afinidade pela lectina DBA por citometria de fluxo

4.2.3.2 Deteção da expressão de PGP9.5 por reação de imunofluorescência em células espermatogoniais de bovinos adultos

4.2.3.3 Expressão gênica dos marcadores ITGA6, GFRa-1 e PGP9.6 em células espermatogoniais de bovinos adultos 65

4.2.4 Marcação das células espermatogoniais de bovinos adultos com PKH26 .65

4.2.5 Transformação das células espermatogoniais de bovinos adultos 67 4.2.6 Injeção de corante azul de tripan em testículos de bovinos adultos .68 
5 CAPÍTULO 2: Células espermatogoniais bovinas LacZ+ podem integrar-se aos túbulos seminíferos de bezerros pré-púberes da raça Nelore após transplante autólogo? ..........................................................73

5.1 MATERIAIS E MÉTODOS...........................................................

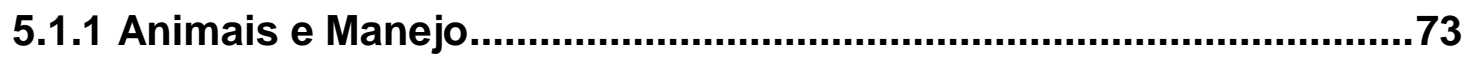

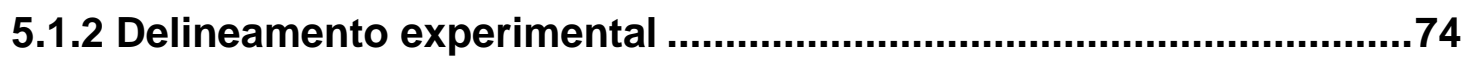

5.1.3 Isolamento de células espermatogoniais de bovinos pré-púberes .75

5.1.3.1 Orquiectomia unilateral do testículo doador .....................................75

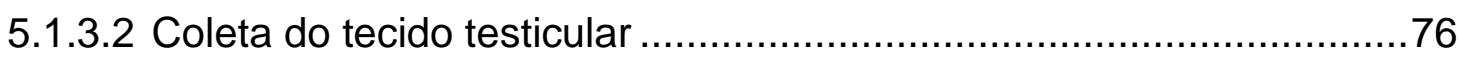

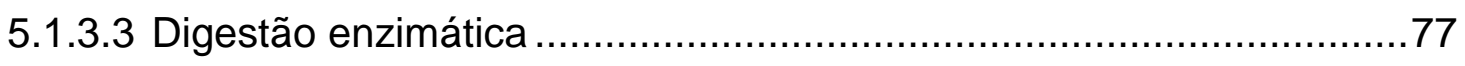

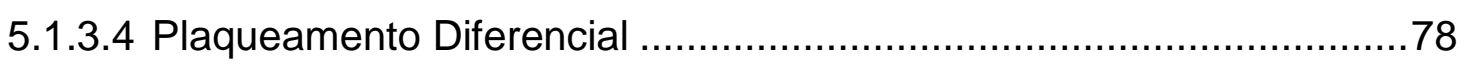

5.1.4 Transdução das células espermatogoniais de bovinos pré-púberes

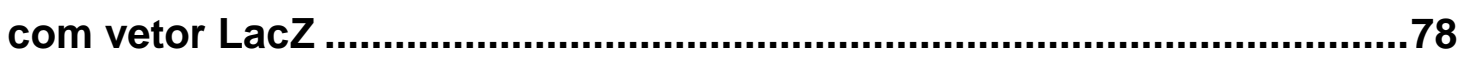

5.1.5 Preparo das células espermatogoniais para 0 transplante .79

5.1.6 Transplante autólogo de células espermatogoniais de bovinos prépúberes. .80

5.1.7 Verificação da integração de células espermatogoniais LacZ+ e/ou marcadas com PKH26 aos túbulos seminíferos de bovinos pré-púberes da raça Nelore após transplante autólogo .82

5.1.7.1 Orquiectomia do testículo receptor remanescente. .82

5.1.7.2 Detecção enzimática ( $\mathrm{x}$-gal) de beta-galactosidase..... .84

5.1.7.3 Verificação da presença de células espermatogoniais marcados com o corante PKH26 nos testículos de bovinos pré-púberes após o transplante autólogo. .86

5.1.8 Caracterização celular. 87

5.1.8.1 Deteção da expressão de PGP9.5 e alfa-6 integrina por reação de imunofluorescência e afinidade pela lectina DBA de células espermatogoniais de bovinos pré-púberes

5.1.8.2 Expressão gênica dos marcadores ITGA6, GFRa-1 e PGP9.6 em células espermatogoniais de bovinos pré-púberes. .88 
5.1.8.3 Detecção da expressão de PGP9.5 por imuno-histoquímica e afinidade por DBA em amostras de tecido dos testículos doadores de células espermatogoniais de bovinos pré-púberes.

5.1.9 Análise Estatística .91

5.2 RESULTADOS

5.2.1 Isolamento de células espermatogoniais de bovinos pré-púberes.92

5.2.1.1 Digestão enzimática .92

5.2.1.2 Plaqueamento Diferencial .93

5.2.2 Verificação da integração de células espermatogoniais LacZ+ e/ou marcadas com PKH26 aos túbulos seminíferos de bovinos pré-púberes da raça Nelore após transplante autólogo .94

5.2.2.1 Orquiectomia do testículo receptor remanescente 94

5.2.2.2 Detecção enzimática (x-gal) de beta-galactosidase

5.2.2.3 Verificação da presença de células espermatogoniais marcados com o corante PKH26 nos testículos de bovinos pré-púberes após o transplante autólogo. .98

5.2.3 Caracterização celular. 98

5.2.3.1 Deteção da expressão de PGP9.5 e alfa-6 integrina por reação de imunofluorescência e afinidade pela lectina DBA de células espermatogoniais de bovinos pré-púberes 98

5.2.3.2 Expressão gênica dos marcadores ITGA6, GFRa-1 e PGP9.6 em células espermatogoniais de bovinos pré-púberes. 102

5.2.3.3 Detecção da expressão de PGP9.5 por imuno-histoquímica e afinidade por DBA em amostras de tecido dos testículos doadores de células espermatogoniais de bovinos pré-púberes. 103

5.3 DISCUSSÃO 106

5.3.1 Isolamento e cultivo in vitro de células espermatogoniais de bovinos pré-púberes .107

5.3.2 Verificação da integração de células espermatogoniais LacZ+ e/ou marcadas com PKH26 aos túbulos seminíferos de bovinos pré-púberes da raça Nelore após transplante autólogo 108 


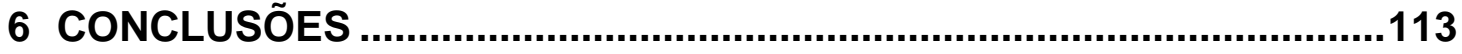

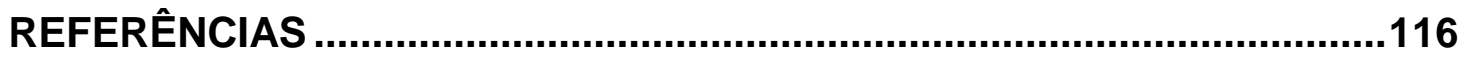


INTRODUÇÃO 


\section{INTRODUÇÃO}

A espermatogênese em mamíferos é um processo dependente de célulastronco adultas clássico, sustentado pelas células-tronco espermatogoniais (SSC, do inglês spermatogonial stem cells). As SSCs são consideradas células-tronco por serem células indiferenciadas e possuírem a capacidade de auto-renovação, ou seja, dividir-se mitoticamente sem que ocorra sua diferenciação e a capacidade de produzir células que irão prosseguir com a diferenciação celular. Esta capacidade as tornam fundamentais à espermatogênese, pois garante a manutenção da população das células mais indiferenciadas no testículo e o suprimento de espermatozoides por toda a vida do macho. Embora consideradas células-tronco, as SSCs são unipotentes, ou seja, podem gerar apenas um tipo de célula. O estudo dessas células oferece excelente modelo para entender melhor a biologia das células-tronco adultas e decifrar os mecanismos que controlam as funções das SSCs.

Estima-se que uma única SSC pode dar origem a mais de 4 mil espermatozóides e sabe-se que, em mamíferos, milhões de espermatozóides são produzidos todos os dias a partir das SSCs (MEISTRICH; VAN BEEK, 1993). Sabese que essas células têm capacidade de se replicar nos túbulos seminíferos após transplante, participando da espermatogênese no testículo receptor. Se forem unidos estes dois conhecimentos sobre as SSCs, pode-se dizer que essas células possuem grande potencial na biotecnologia animal para produção de animais transgênicos. Tal hipótese baseia-se na possibilidade de manipular o genoma de uma SSC e transplantá-la para um testículo de um reprodutor. Os espermatozóides transgênicos produzidos por este reprodutor poderão, finalmente, ser utilizados na produção de animais transgênicos. Um animal doméstico transgênico pode servir como biorreator, produzindo substâncias heterólogas de grande interesse para a indústria farmacêutica.

Os primeiros transplantes bem sucedidos de SSCs foram realizados em camundongos e ratos. Hoje em dia, o sucesso da técnica já foi conseguido também em espécies domésticas como a suína, caprina e bovina. Em bovinos, além do interesse em transgênese, o transplante de SSCs despertou a atenção de sistemas comerciais de criação. Um exemplo de aplicação zootécnica é a disseminação da 
genética de touros considerados elite através de touros de menor valor comercial. Uma vez realizada a depleção química da espermatogênese nos testículos receptores, as SSCs do animal doador poderão restabelecer a espermatogênese no receptor. Além disso, o cultivo in vitro em larga escala de SSCs poderá prover fonte teoricamente inesgotável de células para transplante. Foram realizados com sucesso transplantes autólogos e homólogos na espécie bovina, incluindo transplante de SSCs entre animais taurinos e zebuínos.

Dada a importância do estudo de SSCs e de seu promissor uso em transgenia animal ou mesmo no âmbito zootecnológico, o presente trabalho teve como objetivos caracterizar, transformar geneticamente e transplantar SSCs de bezerros pré-púberes da raça Nelore para verificar se SSCs bovinas transgênicas são capazes de se integrar aos túbulos seminíferos quando transplantadas autologamente. Para isso, este estudo foi dividido em dois capítulos, o primeiro refere-se à padronização das técnicas de isolamento, cultivo in vitro, caracterização, transformação genética e transplante de SSCs e o segundo capítulo à execução de todos estes procedimentos em bezerros pré-púberes da raça Nelore. 


\section{REVISÃO DE LITERATURA}

\subsection{CÉLULAS-TRONCO ESPERMATOGONIAIS}

\subsubsection{Definição e função das SSCs na espermatogênese}

A espermatogênese é um processo no qual a maioria das pessoas raramente pensa a respeito embora represente um dos eventos biológicos fundamentais, sem o qual a vida como conhecemos não existiria. Podemos dizer que a espermatogênese é um processo longo, complexo, altamente ordenado e bem definido responsável pelo suprimento contínuo de espermatozoides durante toda a vida do macho (RUSSELL, 1990). Ela ocorre nos túbulos seminíferos, que são estruturas tubulares, organizadas em espiral, presentes no parênquima testicular. Na membrana basal dos túbulos seminíferos encontramos as células-tronco espermatogoniais (SSC, do inglês spermatogonial stem cells). Tendo em vista que, em mamíferos, milhões de espermatozoides são produzidos todos os dias a partir das SSCs (MEISTRICH; VAN BEEK, 1993), sua constante replicação nos túbulos seminíferos as torna fundamentais para a manutenção da espermatogênese.

A espermatogênese compreende todas as transformações celulares que ocorrem às células germinativas masculinas no epitélio seminífero. A espermatogênese começa com uma etapa denominada fase proliferativa, composta pela pelas divisões mitóticas das SSCs. Tal fase é fundamental para a manutenção da espermatogênese durante toda a vida reprodutiva do macho, pois nela novas SSCs são formadas para manter a fonte de células-tronco do testículo (RUSSELL, 1990; DE ROOIJ, D. G.; RUSSELL, 2000). A segunda fase da espermatogênese é a fase meiótica, na qual encontramos células germinativas mais diferenciadas, os espermatócitos primários e secundários. A segunda fase culmina na produção de células haploides, denominadas espermátides. A última fase da espermatogênese é 
a fase de diferenciação, na qual não são mais observadas divisões celulares. Nesta etapa, as espermátides redondas sofrem alterações morfológicas e físicas até a formação de células completamente diferenciadas e altamente especializadas, os espermatozoides.

\subsubsection{Origem das SSCs}

Os testículos nos mamíferos estão presentes em par e essencialmente realizam duas funções, produção de espermatozoides e esteroidogênese. Em vertebrados há a diferenciação entre as células da linhagem germinativa e células somáticas. Nestes organismos, as células germinativas se diferem das somáticas durante o início do desenvolvimento embrionário e não têm sua origem embrionária nas gônadas. Suas células precursoras, conhecidas por Células Germinativas Primordiais (PGC, do inglês primordial germ cells) são difíceis de serem distinguidas das células somáticas nos primeiros estágios da embriogênese (LAWSON; PEDERSEN, 1992). Em 1987, Hahnel e Eddy, demonstraram que as PGCs estão originalmente presentes nos epiblastos de embriões murinos no estágio de gástrula. Sabe-se que em murinos, as PGCs migram pelo alantóide para o embrião propriamente dito (LAWSON; HAGE, 1994). Contudo, o mecanismo pelo qual as PGCs obedecem à rota a ser seguida durante sua migração até as gônadas ainda é desconhecido. Ao atingir a crista urogenital, as PGCs se dividem em duas populações, habitando os dois lados desta estrutura, fazendo parte da gônada embrionária. Na crista genital, as PGCs são envolvidas pelas células de Sertoli em diferenciação, dando início a formação dos cordões espermáticos, que por sua vez formarão os túbulos seminíferos (BYSKOV; HØYER, 1994). Ao final da gestação, os gonócitos permanecem quiescentes, ou seja, estacionados em G0/G1 da divisão celular. Os gonócitos permanecem quiescentes até aproximadamente 3 dias após 0 nascimento em camundongos e transformam-se em SSCs do tipo A aos 6 dias de vida (BELLVÉ et al., 1977). Este período pode ser de até meses em animais de produção ou anos em humanos. O mecanismo pelo qual os gonócitos dão origem a várias SSCs ainda não é conhecido. 


\subsubsection{Divisão celular das SSCs}

Para facilitar a compreensão da classificação das SSCs, é preciso conhecer um pouco mais sobre sua divisão celular durante a fase proliferativa da espermatogênese. Como vimos, as SSCs podem optar pela auto-renovação, ou seja, produzir células filhas idênticas à célula mãe, ou gerar células filhas já comprometidas com a diferenciação. Essa tomada de decisão sobre o destino das SSCs está ilustrada na Figura 1. Quando da ocorrência da auto-renovação, duas novas SSCs são formadas. É através desse processo que é feita a manutenção da espermatogênese durante toda a vida do macho. Quando a divisão celular gera células filhas comprometidas com a diferenciação, estas prosseguirão sua diferenciação durante a espermatogênese até a formação do espermatozoide (HUCKINS, C; OAKBERG, 1978b; DE ROOIJ, D. G.; RUSSELL, 2000).

Figura 1 - Figura esquemática dos possíveis destinos das SSCs na divisão celular durante a fase de proliferação da espermatogênese em mamíferos

\section{Destino das SSCS}

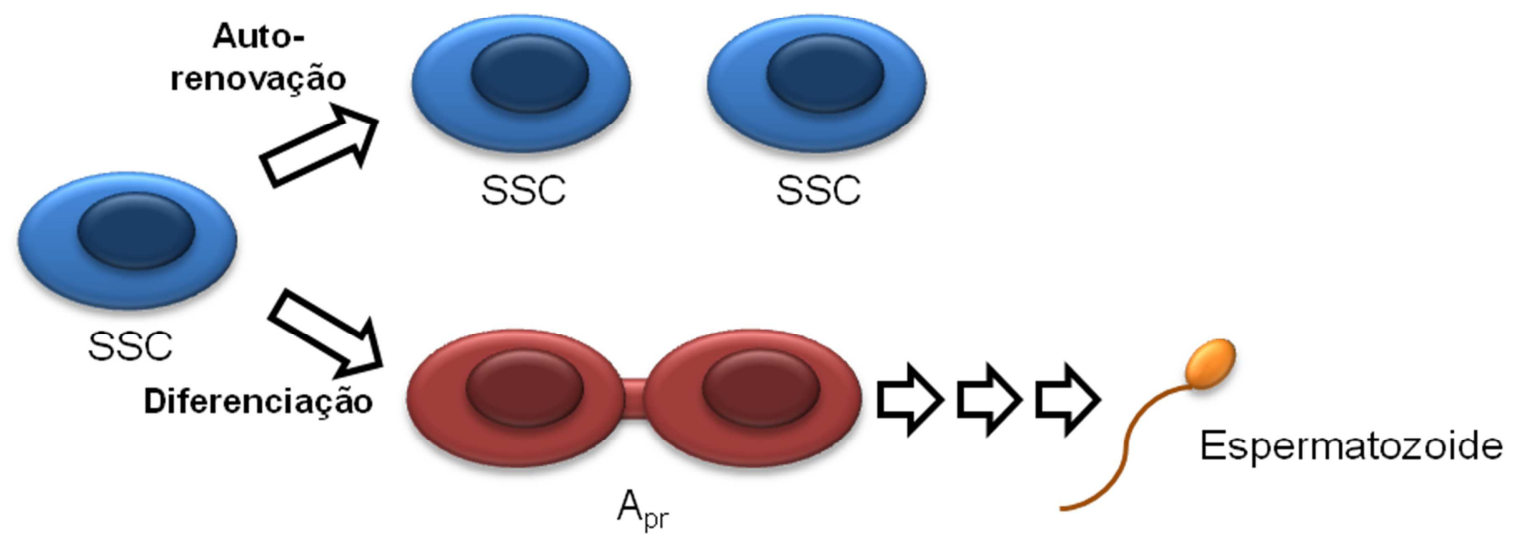

Fonte: adaptado de OATLEY, J. M.; BRINSTER (2008). 
Pontes citoplasmáticas são áreas de continuidade do citoplasma presentes entre as células filhas observadas após a divisão celular das SSCs, devido a uma interrupção da telófase. Essa comunicação entre as células permite a troca de produtos gênicos e sincronização das atividades celulares, resultando em um desenvolvimento sincronizado (BRAUN et al., 1989; LEE, K. et al., 1995). Quando as células filhas apresentam pontes citoplasmáticas entre elas, sabemos que estão comprometidas com a diferenciação celular (Figura 1). Tais espermatogônias recebem a denominação de SSCs do tipo A pareadas $\left(A_{\text {pr }}\right)$. Dessa maneira, denominamos as espermatogônias simples $\left(A_{s}\right)$, ou seja, sem pontes intercelulares, de SSCs.

Não se sabe exatamente como é tomada a decisão do destino das SSCs. Ainda, a maneira como ocorre sua divisão, simétrica ou assimetricamente, é desconhecida (DE ROOIJ, D. G.; RUSSELL, 2000). Considerando a divisão das SSCs como simétrica, o destino das células filhas seria dependente de mecanismos regulatórios que vão determinar a formação ou não das pontes citoplasmáticas (Figura 1). Se não houver conexão entre as células filhas, duas novas SSCs são geradas por auto-renovação. Se houver a formação das pontes citoplasmáticas, ambas células formadas darão continuidade à espermatogênese. Considerando a possibilidade da divisão celular das SSCs ser assimétrica (Figura 2), as SSCs se dividiriam em uma SSC e outra célula simples que produz duas células filhas pareadas em sua primeira divisão. A outra célula filha, por sua vez, produz novas SSCs na próxima divisão. A divisão assimétrica das SSCs foi sugerido em 1971 por Huckins, mas ainda não foi confirmada (DE ROOIJ, D. G.; RUSSELL, 2000). Assim, adota-se a hipótese de que SSCs sofrem divisões simétricas e que somente as SSCs do tipo $A_{S}$ são verdadeiras células-tronco.

De acordo com o modelo de divisão das SSCs proposto por Huckins e Oakberg (1978) para murinos, as SSCs do tipo $A_{p r}$ se dividem formando cadeias de 4, 8 ou 16 células espermatogoniais alinhadas $\left(A_{a l}\right)$. As espermatogônias $A_{a l}$, por sua vez, se diferenciam em células $A_{1}$. Nas divisões subsequentes, células $A_{2-4}$ são formadas até o surgimento das $A$ intermediárias $\left(A_{i}\right)$ pela divisão das células $A_{4}$. As SSCs $A_{i}$ se dividem em SSCs do tipo $B$. É a espermatogônia do tipo $B$ dá origem aos espermatócitos primários que iniciarão a meiose da espermatogênese (HOFMANN, 2008). 
Figura 2 - Esquemática dos possíveis tipos de divisão celular das SSCs durante fase de proliferação da espermatogênese em mamíferos

\section{Divisão Simétrica}

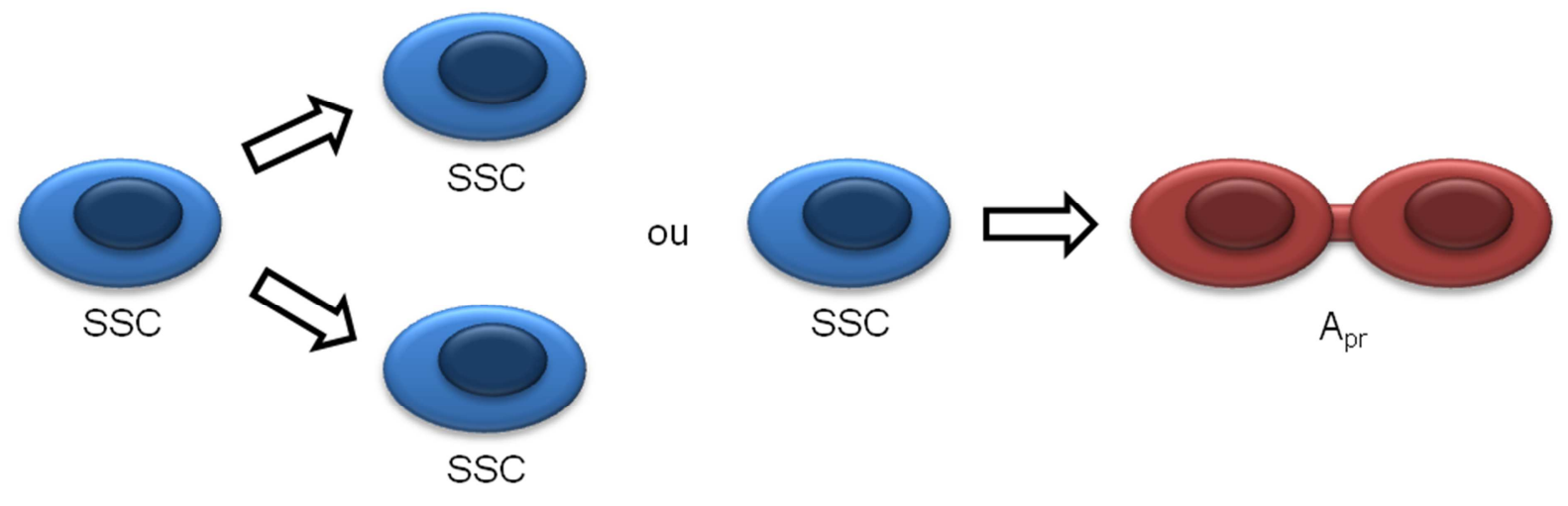

Divisão Assimétrica

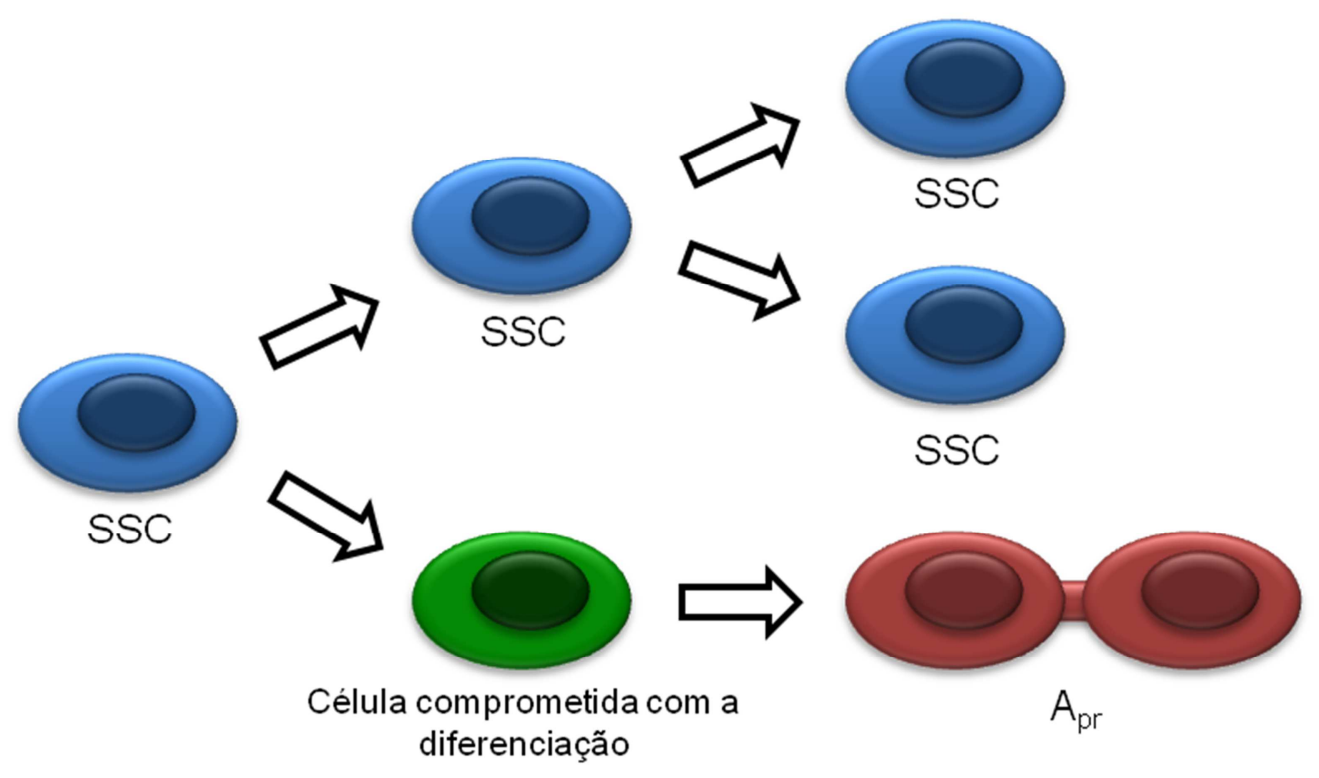

Fonte: adaptado de OATLEY, J. M.; BRINSTER (2008).

\subsubsection{Classificação}

Em camundongos, sete tipos de espermatogônia tipo $A$ já foram identificados e classificados de acordo com as divisões mitóticas das SSCs: $A_{\text {simples }}\left(A_{s}\right), A_{\text {pareada }}$ $\left(A_{p r}\right), A_{\text {alinhada }}\left(A_{a l}\right), A_{1}, A_{2}, A_{3}$ e $A_{4}$ (DE ROOIJ, D.G., 1998; DETTIN et al., 2003). As espermatogônias $A_{S}$ são consideradas as SSCs nesta espécie. As espermatogônias 
$A_{p r}$ e $A_{a l}$, embora indiferenciadas, formam colônias expandidas das SSC, pois já sofreram mitoses. Pelo fato das divisões mitóticas serem incompletas, essas células não possuem a capacidade de auto-renovação como as espermatogônias $A_{s}$. As espermatogônias $A_{1}-A_{4}$ também formam colônias expandidas das SSCs que se encontram sincronizadas com o ciclo do epitélio seminífero. Portanto as espermatogônias $A_{1}-A_{4}$ já estão comprometidas com a formação dos futuros espermatozoides. Em camundongos, foram identificadas espermatogônias dos tipos B e Intermediária, estas já diferenciadas (DE ROOIJ, D.G., 1998; DETTIN et al., 2003). Em ratos também existem sete tipos de espermatogônia $A$ concordando com o que se observa em camundongos, sendo somente as espermatogônias $A$ consideradas SSCs (HUCKINS, C; OAKBERG, 1978A).

Para a espécie bovina, uma classificação para as espermatogônias do tipo $A$, baseada na classificação existente para camundongos, foi proposta por Wrobel et al. (1995). De acordo com essa classificação, existem as células-tronco espermatogoniais basais (BSC - do inglês: "basal stem cells") correspondentes às espermatogônias $A_{s}$ e $A_{p r}$; células precursoras de espermatogônias agregadas (ASPC - do inglês: "aggregated spermatogonial precursor cells") correspondentes às espermatogônias $A_{a l}$ e, finalmente, células precursoras de espermatogônias comprometidas (CSPC do inglês: "commited spermatogonial precursor cells") correspondentes às espermatogônias $A_{1}-A_{4}$. Assim, foi sugerido para touros que as espermatogônias $A_{p r}$ também possuíam propriedades de células-tronco (WROBEL et al., 1995). Diversos grupos têm estudado protocolos de isolamento e purificação de SSC em bovinos (IZADYAR, F et al., 2002; OATLEY, J.M.; REEVES; MCLEAN, 2004; BI et al., 2007; HUANG; SARTINI; PARKS, 2008) e, até o presente momento, os protocolos que ofereceram melhores resultados consistem no isolamento de todas as espermatogônias do tipo A.

\subsection{CARACTERIZAÇÃO DE CÉLULAS-TRONCO ESPERMATOGONIAIS}

A população de células-tronco em um determinado tecido adulto é estabelecida e mantida em microambientes especializados denominados nichos. 
Este conceito foi primeiramente proposto por Schofield, em 1978, para sistemas hematopoiéticos. O nicho desempenha um papel importante nas decisões das células-tronco (auto-renovação ou diferenciação celular), e envolve uma série de mecanismos regulatórios com sinais celulares entre as células-tronco, suas filhas em diferenciação, células vizinhas e matriz extracelular. Em mamíferos, a localização anatômica do nicho das SSCs não está claramente (HOFMANN, 2008). O nicho das SSCs é composto por células de Sertoli, membrana basal e componentes celulares do espaço intersticial entre os túbulos seminíferos. Dentre os sinais regulatórios que agem no nicho das SSCs podemos citar os fatores de crescimento produzidos pelas células de Sertoli (SIMON et al., 2007), moléculas de adesão que ligam as SSCs aos componentes da membrana basal, como a laminina (ORWIG et al., 2002) e estímulos da rede vascular e células intesticiais.

Por SSCs estarem intimamente associadas à membrana basal nos túbulos seminíferos, a alfa-6 integrina tem sido investigada como marcador na caracterização destas células. Sabe-se que integrinas são moléculas presentes na superfície da membrana celular e atuam como receptores de adesão celular. Essas moléculas compõem a família de glicoproteínas transmembrânicas que possuem estruturas heterodímeras (HYNES, 1992). As integrinas facilitam a adesão das células à matrix extracelular (ECM) e migração celular mediante adesão entre células, ligando ECM a elementos do citoesqueleto; além de atuarem como moléculas de sinalização celular (FÉNICHEL; DURAND-CLÉMENT, 1998). A expressão deste marcador foi primeiramente reportada em ratos em 1995 por Salanova e colaboradores. Em 1999, Shinohara e colaboradores, através de MACS utilizando anticorpos para alfa-6 integrina obtiveram populações de SSCs do tipo A oito vezes mais puras do que o controle não purificado. Embora diversos grupos venham utilizando este marcador para SSCs humanas (IZADYAR, F et al., 2011) e suínas (KUIJK; COLENBRANDER; ROELEN, 2009) sua expressão em SSCs bovinas ainda não foi verificada.

Sabe-se que células de Sertoli secretam GDNF que atuam na manutenção do estado indiferenciado das SSCs (TRUPP et al., 1995; GOLDEN; DEMARO; OSBORNE, 1999; MENG; LINDAHL; HYVONEN, 2000). Assim, seu receptor alfa-1 da família GDNF (GFRa-1) tem sido utilizado como marcador para SSCs. Sua expressão já foi utilizada na caracterização de SSCs murinas (HOFMANN; 
BRAYDICH-STOLLE; DYM, 2005) ratuínas (GASSEI; EHMCKE; SCHLATT, 2009) e mesmo bovinas (OATLEY, J.M.; REEVES; MCLEAN, 2004; Bl et al., 2007). Outro marcador molecular que já foi utilizado para SSCs bovinas é a ubiquitina hidrolase C-terminal L1 (UCHL1) também conhecida por PGP9.5 (WROBEL et al., 1995; HERRID; DAVEY; HILL, 2007). Pode-se dizer que a caracterização de SSCs já está bem definida para murinos e aconselha-se utilizar mais de um marcador para sua caracterização. O mesmo não pode se dizer da espécie bovina. Como pudemos observar, poucos marcadores estão definidos, o que impede a elaboração de melhores protocolos de isolamento e manutenção in vitro de SSCs indiferenciadas.

\subsection{ISOLAMENTO E CULTIVO IN VITRO DE CÉLULAS-TRONCO ESPERMATOGONIAIS}

O primeiro passo para se trabalhar com SSCs in vitro é fazer o seu isolamento. No entanto, sabe-se que no camundongo somente $0,03 \%$ das células germinativas são SSCs (TAGELENBOSCH; DE ROOIJ, 1993). Portanto, procura-se separar as SSCs das outras células germinativas e, para isso, o momento da recuperação dessas células tem se mostrado muito importante. Kanatsu-Shinohara et al. (2004) isolaram SSCs de camundongos recém-nascidos (0-2 dias de vida), pois nessa idade os tipos mais primitivos de espermatogônia predominam no testículo desses animais. Guan et al. (2006) obtiveram populações de SSCs menos puras quando usaram testículos de camundongos com 4-6 semanas de vida. A purificação dessas células foi feita pela expressão do gene STRA8 (do inglês: "stimulated by retinoic acid gene 8"), que é expresso por todas as células prémeióticas. Seandel et al. (2007) isolaram células germinativas de camundongos com 3-5 semanas de idade e também observaram populações menos puras de SSCs. Sugere-se, então, que o isolamento de células germinativas de animais mais jovens favorece a seleção de populações mais puras de SSCs na espécie murina (DE ROOIJ, D.G.; MIZRAK, 2008) e acredita-se que o mesmo ocorre na espécie bovina. Izadyar et al. (2002) obtiveram população com 65-87\% de espermatogônias do tipo $A$, isolando células germinativas de bezerros com 5-7 meses de idade. Ainda nesse 
estudo, observou-se que testículos de animais com 5 meses de idade foram a melhor fonte de espermatogônias do tipo A. Bi et al. (2007) isolaram SSCs de testículos de bezerros com 5 meses de idade. Oatley et al. (2004) isolaram células germinativas de bovinos com 1-2 meses de idade e tiveram bons resultados com a criopreservação dessas células.

Outro fator importante na obtenção das SSCs é o protocolo adotado tanto para o isolamento das células germinativas quanto para a purificação das SSCs. Um método que tem oferecido bons resultados no isolamento de células germinativas é a digestão enzimática do parênquima testicular (BELLVÉ et al., 1977; VAN PELT et al., 1996). Nessa técnica, a túnica albugínea é dissecada e fragmentos do parênquima testicular são retirados e incubados com solução contendo hialuronidase, tripsina e colagenase. Essa técnica tem sido empregada com algumas modificações para camundongos (KANATSU-SHINOHARA, M., 2003) bovinos (IZADYAR, F et al., 2002; OATLEY, J M et al., 2002; $\mathrm{Bl}$ et al., 2007) e suínos (DOBRINSKI; AVARBOCK; BRINSTER, 2000).

A obtenção de quantidade suficiente de SSCs é pré-requisito para o sucesso de seu cultivo in vitro. Assim, dentre as principais técnicas para purificação das SSCs a partir da suspensão de células germinativas, podemos destacar a centrifugação por gradiente descontínuo de Percoll (VAN PELT et al., 1996), a reação de imunohistoquímica com DBA (do inglês Dolichos biflorus agglutinin) (ERTL; WROBEL, 1992; IZADYAR, F et al., 2002) e o plaqueamento diferencial (IZADYAR, F et al., 2002). A pureza da suspensão de células alcançada por essas técnicas pode ser estimada por microscopia diferencial de Nomarski. Herrid et al. (2009) comparou a eficiência do plaqueamento diferencial utilizando laminina, do gradiente descontínuo de Percoll, da separação celular ativada magneticamente (MACS, do inglês magnetic activated cell sorting) e da separação celular por citometria de fluxo (FACS, do inglês flow citometry cell sorting) na purificação de SSCs bovinas. Foi observado que o plaqueamento diferencial utilizado forneceu o maior número de SSCs do tipo A para serem transplantadas enquanto a MACS forneceu maior número de SSCs do tipo A viáveis para cultivo in vitro. Estes autores sugeriram, ainda, que a combinação de técnicas e purificação podem aumentar a quantidade de SSCs do tipo A obtidas. 
O cultivo in vitro das SSCs enfrenta obstáculos semelhantes aos observados comumente em cultivos de células-tronco adultas. Contudo, muitos avanços já foram feitos nessa área, existindo na literatura protocolos que têm apresentado resultados satisfatórios. Sabe que o GDNF (do inglês glial cell line-derived neurotrophic factor) atua na auto-renovação de SSCs in vivo (MENG; LINDAHL; HYVONEN, 2000) e in vitro (NAGANO et al., 2003; KUBOTA; AVARBOCK; BRINSTER, 2004a; APONTE et al., 2006) observaram que a adição de GDNF é benéfica ao cultivo in vitro de SSCs bovinas, auxiliando na manutenção da pluripotência e auto-renovação dessas células. O co-cultivo com monocamadas de outros tipos celulares como fibroblastos fetais murinos mitoticamente inativados (MEF, do inglês murine embryonic fibroblasts) ou linhagem imortal de fibroblastos fetais murinos STO mitoticamente inativados (NAGANO et al., 1998) são discutíveis e apresentaram diferentes resultados até o momento. O MEF é amplamente utilizado no cultivo in vitro de células-tronco (EVANS; KAUFMAN, 1981) e tem sido usado com sucesso no cocultivo de SSCs murinas (KANATSU-SHINOHARA, MITO; TOYOKUNI; SHINOHARA, 2004). Oatley et al. (2002) utilizaram células STO para cultivar SSCs bovinas e em (2004) o mesmo grupo desenvolveu uma linhagem de fibroblastos fetais bovinos (BEF, do inglês bovine embryonic fibroblasts) que se mostrou eficaz na manutenção do cultivo in vitro de SSCs bovinas. No entanto, Lee et al. (2001) e Aponte et al. (2006) obtiveram sucesso no cultivo in vitro de SSCs bovinas sem cocultivo. Izadyar et al. (2003) utilizaram uma matriz extracelular, a base de laminina para manter SSCs bovinas indiferenciadas in vitro.

Após o estabelecimento do cultivo in vitro das SSCs bovinas, é necessário realizar ensaio biológico para verificar a preservação da capacidade dessas células em restabelecer a espermatogênese in vivo. A habilidade de transferir espermatogônias entre machos (doador-receptor), resultando na produção de espermatozóides maduros do macho doador pelo testículo receptor, já foi reportada em camundongos (BRINSTER; AVARBOCK, 1994; BRINSTER; ZIMMERMANN, 1994). Oatley et al. (2002)demonstraram que SSCs bovinas cultivadas in vitro são capazes de colonizar os túbulos seminíferos de camundongos após o transplante. 


\subsection{CÉLULAS-TRONCO ESPERMATOGONIAIS E SUAS APLICAÇÕES}

O estudo dessas células proporciona um excelente modelo para entendermos melhor a biologia das células-tronco adultas e decifrarmos os mecanismos que controlam as funções das SSCs. Além do potencial biomédico dessas células para estudos sobre infertilidade em machos de diferentes espécies (DOBRINSKI, 2005) as SSCs possuem grande potencial na biotecnologia animal como a produção de animais transgênicos (BRINSTER; AVARBOCK, 1994). Um animal doméstico transgênico pode servir como biorreator, produzindo substâncias de grande interesse da indústria farmacêutica. Além disso, a transgenia animal tem se tornado uma ferramenta essencial para o estudo de mecanismos e funções de expressão gênica.

O primeiro animal doméstico transgênico foi produzido em 1985 pela microinjeção do DNA exógeno no pró-núcleo do zigoto (HAMMER et al., 1985). Visto que a técnica de microinjeção possui muitas dificuldades, como integração aleatória do transgene ao genoma hospedeiro, baixa eficiência e alta frequência de mosaicismo, técnicas alternativas têm sido desenvolvidas para a produção de animais domésticos transgênicos (KUES; NIEMANN, 2004). Dentre elas podemos destacar a transferência gênica mediada por espermatozoides (SMGT, do inglês sperm mediated gene transfer) (GANDOLFI, 1998; LAVITRANO et al., 2002).

Assim, a possibilidade de manipular o genoma das SSCs por técnicas de transgenia já estabelecidas abre caminhos para futuros projetos na área de transgenia animal. Existem alguns grupos ao redor do mundo interessados em modificar SSCs. A maioria deles tem testado vetores virais, sendo os retrovírus e lentivírus os mais utilizados. Contudo, é possível encontrar apenas trabalhos com SSCs de ratos utilizando retrovírus ou lentivírus (KANATSU-SHINOHARA et al., 2006, 2008); de camundongos utilizando retrovírus (NAGANO et al., 2000, 2001) ou SSCs de ratos utilizando apenas lentivírus (RYU et al., 2007). Os Laboratórios de Fecundação in vitro, Clonagem e Transgenia Animal da Faculdade de Medicina Veterinária e Zootecnia da Universidade de São Paulo (FMVZ-USP) têm desenvolvido trabalhos em busca do estabelecimento de técnicas de transgenia animal que possam ser aplicadas como ferramentas biotecnológicas há mais de 10 
anos. Visto que até o momento, não foram produzidas SSCs bovinas transgênicas, decidiu-se testar SSCs bovinas para a produção de animais transgênicos. Para isso, células espermatogoniais bovinos foram isoladas, cultivadas in vitro, transformadas com a inserção do gene marcador LacZ e transplantadas para o testículo de bezerros pré-puberes. 
OBJETIVOS

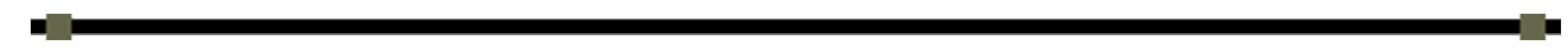




\section{OBJETIVOS}

Este trabalho teve como principal objetivo responder à questão:

"Células espermatogoniais bovinas LacZ+ podem integrar-se aos túbulos seminíferos de bezerros pré-púberes da raça Nelore após transplante autólogo?"

Para responder à pergunta acima, foram propostos os seguintes objetivos específicos:

1. Isolar e cultivar in vitro células espermatogoniais de bezerros pré-púberes da raça Nelore submetidos à orquiectomia unilateral;

2. Avaliar o grau de diferenciação das células espermatogoniais após o isolamento enzimático, verificando a expressão dos marcadores alfa-6 integrina, GFR $\alpha-1$, PGP9.5 e afinidade pela lectina DBA;

3. Transformar as células espermatogoniais cultivadas in vitro com a introdução do gene marcador LacZ;

4. Transplantar autologamente as células espermatogoniais contendo o gene LacZ;

5. Avaliar a integração das células espermatogoniais transgênicas nos testículos transplantados 45 dias após o transplante. 
CAPÍTULO 1: ISOLAMENTO DE CÉLULAS ESPERMATOGONIAIS ADULTAS 


\section{CAPÍTULO 1: ISOLAMENTO DE CÉLULAS ESPERMATOGONIAIS ADULTAS}

Para a padronização das técnicas de isolamento, cultivo in vitro, caracterização, transformação genética e transplante foram utilizados testículos de touros abatidos comercialmente.

\subsection{MATERIAIS E MÉTODOS}

\subsubsection{Isolamento de células espermatogoniais de bovinos adultos}

Para padronização da técnica de isolamento de SSCs bovinas foi adotado protocolo baseado no descrito por Izadyar al. (2002), com modificações. Para isto, testículos coletados de animais destinados ao abate comercial (Frigorífico Angelelli, Piracicaba, SP) foram coletados em solução salina a $32^{\circ} \mathrm{C}$ e levados ao laboratório em recipiente térmico. No laboratório, os testículos foram lavados e a túnica vaginal parietal removida. Os testículos foram incisados longitudinalmente e fragmentos (aproximadamente $10 \mathrm{~g}$ ) do parênquima testicular próximo à túnica albugínea foram coletados com auxílio de pinça anatômica e tesoura cirúrgica. Os fragmentos de

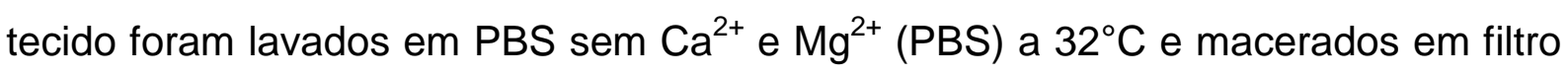
de chá estéril com auxílio de um êmbolo de seringa de $10 \mathrm{~mL}$. Para a digestão enzimática, o tecido processado foi transferido para tubos cônicos de centrífuga de $50 \mathrm{~mL}$ contendo $25 \mathrm{~mL}$ DMEM digestão (Anexo A) e incubado a $32^{\circ} \mathrm{C}$ em banhomaria por 30 min. Os tubos foram centrifugados a $400 \times \mathrm{g}$ por 1 min e o sedimento, contendo túbulos seminíferos, foi ressuspendido em $25 \mathrm{~mL}$ de meio DMEM digestão e incubado novamente a $32^{\circ} \mathrm{C}$ em banho-maria por $30 \mathrm{~min}$. As células foram lavadas em DMEM contendo 10\% (v/v) de FCS (DMEM Cultivo; Anexo B). 


\subsubsection{Purificação das SSCs de bovinos adultos}

\subsubsection{Plaqueamento diferencial}

Após o isolamento, a concentração de células viáveis foi obtida pelo método de exclusão com azul de tripan (5mg/mL em PBS), utilizando hemocitômetro. O isolado de células foi cultivado a $37^{\circ} \mathrm{C}, 5 \%(\mathrm{v} / \mathrm{v}) \mathrm{CO}_{2}$ em ar com alta umidade, em

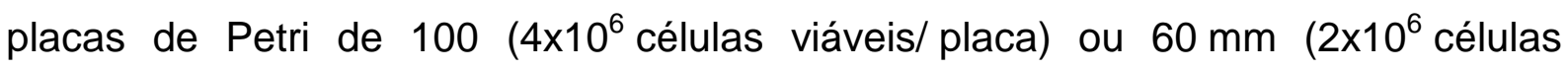
viáveis/ placa) contendo DMEM cultivo durante a noite. Na manhã seguinte, as células em suspensão foram transferidas para uma nova placa contendo DMEM cultivo. Esse procedimento é conhecido como plaqueamento diferencial, no qual as células somáticas se aderem à primeira placa de cultivo na incubação durante a noite (12-18 h), enquanto as células da linhagem germinativa permanecem em suspensão. Ao final do plaqueamento diferencial, somente as células em suspensão foram submetidas ao gradiente descontínuo de Percoll para purificação do tipo A de SSC.

\subsubsection{Gradiente descontínuo de Percoll}

Para a confecção do gradiente descontínuo de Percoll, foram preparadas as soluções 20, 28, 30 e 36\% (v/v) de Percoll em DMEM, correspondendo às densidades 1,0413, 1,0513, 1,0542 e 1,0611 g/mL, respectivamente. Um tubo cônico de $50 \mathrm{~mL}$ foi preenchido com uma camada de $5 \mathrm{~mL}$ de cada densidade do Percoll em ordem crescente, sendo cada camada gentilmente depositada abaixo da anterior. Sobre a camada mais superficial (20\%), foram adicionados $5 \mathrm{~mL}$ de suspensão de células $\left(1 \times 10^{7}\right.$ células viáveis em DMEM) recuperadas após 0 plaqueamento diferencial. A Figura 3 ilustra a preparação do gradiente descontínuo de Percoll em um tubo de $50 \mathrm{~mL}$ para purificação das células espermatogoniais, após plaqueamento diferencial. Foram preparadas camadas alternadas usando DMEM ou 
PBS como diluidor do Percoll para verificar se houve correta montagem sem a mistura das camadas. O uso de camadas alternadas de Percoll diluído em DMEM ou PBS foi utilizado apenas para a verificação da correta montagem do gradiente. Todas as purificações realizadas utilizaram gradientes preparados com DMEM como diluidor.

Após a montagem do gradiente descontínuo de Percoll, o tubo foi centrifugado a $800 \times \mathrm{g}$ por $30 \mathrm{~min}$. Após a centrifugação, $1 \mathrm{~mL}$ de suspensão de células foram foi recuperado de frações entre as camadas de Percoll (Figura 3). Segundo Herrid et al. (2009), a fração 2 oferece maior quantidade de SSCs do tipo A.

Figura 3 - Fotografia do tubo cônico de centrifuga de $50 \mathrm{~mL}$ contendo o gradiente descontínuo de Percoll com camadas de $1,0413(20 \%), 1,0513(28 \%), 1,0542(30 \%)$ e $1,0611(36 \%) \mathrm{g} / \mathrm{mL}$ de Percoll em DMEM ou PBS. Frações 1-4: regiões de onde foram recuperadas células após a centrifugação - São Paulo - 2011

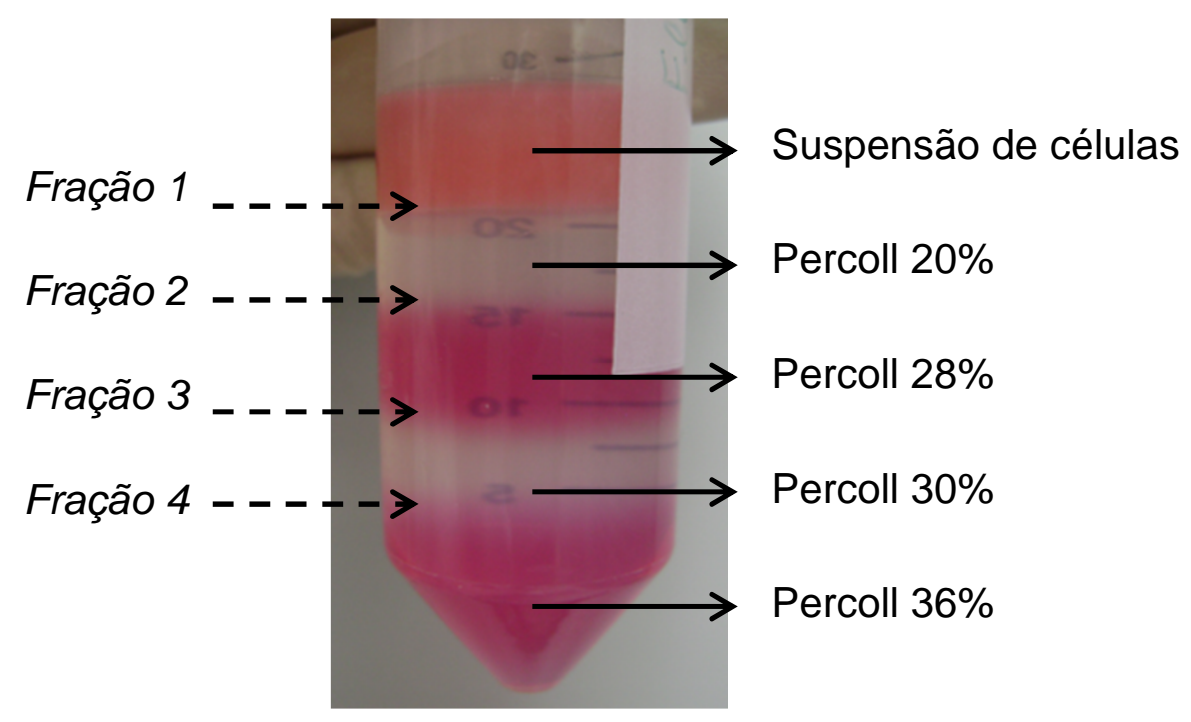




\subsubsection{Caracterização das células espermatogoniais de bovinos adultos}

Para a verificação do grau de indiferenciação das células espermatogoniais, foram escolhidos como marcadores a alfa-6 integrina, o receptor alfa-1 da família GDNF (GFRa-1), a ubiquitina hidrolase C-terminal L1 (UCHL1), conhecida como PGP9.5 e a lectina Dolichus biflorus agglutinin (DBA).

4.1.3.1 Detecção da expressão de alfa-6 integrina e afinidade pela lectina DBA por citometria de Fluxo

Foi realizada a verificação da expressão de alfa-6 integrina e da afinidade das células isoladas pela lectina DBA por citometria de fluxo (Guava EasyCyte ${ }^{\mathrm{TM}}$ Mini System, Guava Technologies, Hayward, CA, EUA). Para isto, células espermatogoniais foram lavadas 3 vezes em PBS e fixadas em etanol 70\% (v/v) gelado $\left(4^{\circ} \mathrm{C}\right)$. As células fixadas ficaram armazenadas à $-20^{\circ} \mathrm{C}$ até o momento da incubação com o anticorpo anti-alfa-6 integrina ou com a lectina.

Para a marcação com 0 anticorpo anti-alfa-6 integrina (Rat monoclonal [GoH3] Integrin alpha 6 associado ao isotiocianato de fluoresceína (FITC), Abcam, Cambridge, MA, EUA), as células fixadas foram centrifugadas a $400 \times \mathrm{g}$ por $5 \mathrm{~min}$ para remoção do etanol. Após serem lavadas em PBS, as células foram ressuspendidas em $90 \mu \mathrm{L}$ de PBS contendo 10\% (v/v) FCS e 1\% (m/v) de azida sódica e $10 \mu \mathrm{L}$ de anticorpo, sendo incubadas por $30 \mathrm{~min}$ a $4^{\circ} \mathrm{C}$. Em seguida, as células foram lavadas 3 vezes em PBS e incubadas com iodeto de propídio (PI, $50 \mu \mathrm{g} / \mathrm{mL}$ em PBS) por $10 \mathrm{~min}$. Após lavagens com PBS (3 vezes), as células foram ressuspendidas em $300 \mu \mathrm{L}$ de PBS e analisadas por citometria de fluxo. Como controle negativo foi preparado um microtubo com células incubadas apenas com PBS contendo FCS e azida sódica e em seguida com PI.

Para a marcação com DBA, foi utilizada a lectina DBA conjugada ao fluoróforo FITC (Sigma). As células fixadas foram lavadas 3 vezes em PBS $(400 \times \mathrm{g} / 5 \mathrm{~min}$ cada) para remoção do etanol. Para bloqueio de sítios inespecíficos, as células 
foram incubadas com solução de $5 \%(\mathrm{~m} / \mathrm{v})$ de albumina sérica bovina (BSA, Sigma) em PBS por 30 min. As células foram lavadas 3 vezes em PBS ( $400 \times$ g/ 5 min cada) e incubadas com $10 \mu \mathrm{g} / \mathrm{mL}$ de DBA em PBS a $37^{\circ} \mathrm{C}$ por $30 \mathrm{~min}$. Em seguida, as células foram lavadas 3 vezes em PBS e incubadas com PI (50 $\mu \mathrm{g} / \mathrm{mL}$ em PBS) por $10 \mathrm{~min}$. Após lavagens com PBS (3 vezes), as células foram ressuspendidas em $300 \mu \mathrm{L}$ de PBS e analisadas por citometria de fluxo. Como controle negativo, foi preparado um microtubo com células incubadas apenas com PBS e em seguida com $\mathrm{PI}$.

Foram avaliados 10.000 eventos e histogramas foram gerados com o eixo $x$ correspondendo ao tamanho das células (forward scatter) e o eixo y à intensidade de marcação com alfa-6 integrina (FITC) ou DBA (FITC). A porcentagem de células marcadas foi calculada, utilizando-se o programa Cytosoft (Guava Technologies, Hayward, CA, EUA).

4.1.3.2 Deteç̧ão da expressão de PGP9.5 por reação de imunofluorescência em células espermatogoniais isoladas de bovinos adultos

Dentre os marcadores escolhidos para a verificação da presença de SSC na população de células espermatogoniais isoladas foi utilizado o anticorpo antiPGP9.5. Após o plaqueamento diferencial, amostras de $1 \times 10^{6}$ células foram fixadas em etanol $70 \%(\mathrm{v} / \mathrm{v})$ gelado $\left(4^{\circ} \mathrm{C}\right)$ e armazenadas a $-20^{\circ} \mathrm{C}$. As amostras fixadas foram lavadas 3 vezes em PBS ( $400 \times$ g/ 5 min cada) para remoção do etanol. Para bloqueio de sítios inespecíficos, as células foram incubadas com solução de $5 \%$ $(\mathrm{m} / \mathrm{v})$ de BSA, em PBS por $30 \mathrm{~min}$, novamente lavadas e incubadas com anticorpo primário (1:100; mouse monoclonal to PGP9.5, ab72911, Abcam, Cambridge, MA, EUA) em PBS contendo $1 \%(\mathrm{~m} / \mathrm{v})$ de BSA a $4^{\circ} \mathrm{C}$ por $12-18 \mathrm{~h}$. Após 3 lavagens em PBS ( $400 \times \mathrm{g} / 5 \mathrm{~min}$ cada), as células foram incubadas com anticorpo secundário (1:200; goat polyclonal secondary antibody to mouse lgG - H\&L FITC, Abcam) por 1 $\mathrm{h}$ a temperatura ambiente no escuro. Após 3 lavagens em PBS, foi realizada última incubação por $15 \mathrm{~min}$ com solução de $5 \mu \mathrm{g} / \mathrm{mL}$ de Hoechst $33342 \mathrm{em}$ PBS. As amostras foram lavadas em PBS e ressuspendidas em $100 \mu \mathrm{L}$ de PBS, sendo $10 \mu \mathrm{L}$ 
colocados entre lâmina e lamínula com uma gota de antifade $D A B C O$. As lâminas foram avaliadas em microscópio de epifluorescência (Olympus) com filtro verde para FITC (comprimentos de onda para excitação e emissão de 488 e 520 nm, respectivamente) e azul para marcação do núcleo celular (Hoechst 33342; comprimentos de onda para excitação e emissão de 345 e 483 nm, respectivamente).

4.1.3.3 Expressão gênica dos marcadores ITGA6, GFRa-1 e PGP9.6 em células espermatogoniais isoladas de bovinos adultos

A verificação da expressão dos marcadores alfa-6 integrina (ITGA6), GFR-1 e PGP9.5 foi realizada por reação de RT-PCR em tempo real. Assim, o RNA total de amostras de células espermatogoniais $\left(1 \times 10^{6}\right.$ células/amostra) foi extraído com Ilustra RNAspin Mini RNA Isolation Kit (GE Healthcare, Buckinghamshire, Reino Unido), seguindo as instruções do fabricante. O RNA total foi eluído da coluna com volume de $100 \mu \mathrm{L}$ de água tratada com dietilpirocarbonato (DEPC). A concentração de RNA total foi verificada por espectrofotometria (Nanodrop ND-1000, Nanodrop Technologies, Inc.,Wilmington, Delaware, EUA) com a finalidade de normalizar as reações de síntese de cDNA. Após a extração, o cDNA foi sintetizado com Superscript ${ }^{\circledR}$ VILOTM $C D N A$ synthesis kit (Invitrogen).

As análises de RT-PCR em tempo real foram realizadas no sistema de detecção Realplex Mastercycler (Eppendorf), utilizando o SYBR GreenERTM qPCR Supermix Universal (Invitrogen) com $10 \mu \mathrm{L}$ de volume por reação. Como controles endógenos foram utilizados os genes gliceraldeído 3-fosfato desidrogenase (GAPDH) e beta actina (ACTB). Os primers foram desenhados com auxílio do software Primer3 (Quadro 1) e Netprimer. Para todas as amplificações, foi utilizado um programa de 3 passos: $95^{\circ} \mathrm{C} / 15 \mathrm{~s}, 55^{\circ} \mathrm{C} / 15 \mathrm{~s}$ e $68^{\circ} \mathrm{C} / 20 \mathrm{~s}$ por 45 ciclos, seguido da curva de dissociação. Como controle negativo da reação utilizou-se a mesma reação sem a adição da amostra de cDNA.

As razões da expressão dos genes alvo (ITGA6, GFR-1 e PGP9.5) foram normalizadas pela razão da expressão dos controles endógenos (ACTB e GAPDH). 
Quadro 1 - Primers utilizados na verificação da expressão dos genes alvo ITGA6, GFRa-1, PGP9.5 e como controles endógenos ACTB e GAPDH

\begin{tabular}{|c|c|c|}
\hline Genes & Primers & $\begin{array}{c}\text { Concentração } \\
\text { (nM) }\end{array}$ \\
\hline \multirow[t]{2}{*}{ ACTB } & F: 5' GTCCACCTTCCAGCAGATGT 3' & 200 \\
\hline & R: 5' GTCACCTTCACCGTTCCAGT 3' & 400 \\
\hline \multirow[t]{2}{*}{ GAPDH } & F: 5' TGACCCCTTCATTGACCTTC 3' & 200 \\
\hline & R: 5' TACTCAGCACCAGCATCACC 3' & 400 \\
\hline \multirow[t]{2}{*}{ ITGA6 } & F: 5’ AGGGATGTGGAGACGACAAC 3' & 400 \\
\hline & R: 5' TCTTTGGTGGGATTCTTTGG 3' & 200 \\
\hline \multirow[t]{2}{*}{ GFR $\alpha-1$} & F: 5' CAAGTGGAGCACATCTCGAA 3' & 400 \\
\hline & R: 5' GGCAGGAACAGAAGAGCATC 3' & 200 \\
\hline \multirow[t]{2}{*}{ PGP 9.5} & F: 5' TGCTGAACAAAGTGCTGACC $3^{\prime}$ & 200 \\
\hline & R: 5' GATGATGGAACCGAGATGCT 3' & 400 \\
\hline
\end{tabular}

\subsubsection{Marcação das células espermatogoniais de bovinos adultos com PKH26}

Para a realização do transplante, as células espermatogoniais foram incubadas com o corante de rastreamento celular PKH26 (Invitrogen). Para a padronização do procedimento, $1 \times 10^{6}$ células viáveis $/ \mathrm{mL}$ obtidas após plaqueamento diferencial foram incubadas com o corante PKH26 $(2 \mu \mathrm{M})$ por $3,5 \mathrm{~min}$ a $25^{\circ} \mathrm{C}$. Em seguida, a suspensão de células com o corante foi incubada com FCS por 1 min e lavadas com DMEM cultivo. Após serem centrifugadas a $400 \times \mathrm{g}$ por $10 \mathrm{~min}$, as células foram ressuspendidas em $300 \mu \mathrm{L}$ de PBS e avaliadas por microscopia de epifluorescência e citometria de fluxo.

Para a avaliação da marcação das células espermatogoniais com PKH26, $10 \mu \mathrm{L}$ de PBS contendo células incubadas com o corante foram colocados entre lâmina e lamínula. As células foram avaliadas em microscopia de epifluorescência 
(Olympus), com o filtro para rodamina (comprimentos de onda para excitação e emissão de 550 e 573 nm, respectivamente).

Para a avaliação da marcação por citometria de fluxo, foram preparados 3 microtubos: um contendo $300 \mu \mathrm{L}$ de suspensão de células incubadas com PKH26, um contendo $300 \mu \mathrm{L}$ de suspensão de células não incubadas com PKH26 e $300 \mu \mathrm{L}$ contendo células incubadas e não incubadas com PKH26 (1:1). Foram avaliados 10.000 células, sendo gerados histogramas com o eixo x correspondendo ao tamanho das células (forward scatter) e o eixo y à intensidade de marcação com alfa-6 integrina (Rodamina). A porcentagem de células marcadas foi calculada utilizando o programa Cytosoft (Guava Technologies, Hayward, CA, EUA).

\subsubsection{Transformação das células espermatogoniais de bovinos adultos}

O vetor LV-LacZ (Addgene) é um vetor lentiviral que contém a seqüência bacteriana LacZ que codifica a proteína beta-galactosidase. A beta-galactosidase cliva o X-gal (5-bromo-4-chloro-3-indolyl- $\beta$-galactopyranoside) em galactose e um produto insolúvel azul. Assim, células transduzidas com este vetor, submetidas à reação com X-gal, tornam-se azuis.

Tanto a produção do vetor lentiviral quanto a transdução das células espermatogoniais bovinas adultas foram realizadas pela equipe do Prof. Dr. Bryam E. Strauss (Setor de Vetores Virais, Laboratório de Genética e Cardiologia Molecular, Instituto do Coração, InCor, FM-USP).

Para a produção das partículas virais, foi realizada a transfecção do DNA viral por precipitação com cálcio-fosfato em células 293T mantidas em meio DMEM com 10\% de FCS. Protocolo adaptado de Naviaux et al. (1996). Foram semeadas, com $24 \mathrm{~h}$ de antecedência, $10^{6}$ células da linhagem HEK293 para transfecção em placas de Petri de $60 \mathrm{~mm}$ previamente tratadas com gel EIA 0,1\% (m/v). Os DNAs foram misturados em $250 \mu \mathrm{L}$ de cloreto de cálcio $0,25 \mathrm{M}$ e precipitados com a adição de $250 \mu \mathrm{L}$ do tampão fosfato de sódio/HEPES HBS-2x pH 7,05 (cloreto de sódio 274 mM, HEPES $40 \mathrm{mM}$, fosfato monoácido de sódio 2,8 mM), sob agitação. A suspensão contendo o precipitado de DNA foi gotejada sobre o meio de cultura das 
células plaqueadas, seguindo-se incubação por $4 \mathrm{~h}$. Após este período, as células foram submetidas ao tratamento com PBS-1x contendo 15\% de glicerol (choque de glicerol) durante 3 min, lavadas com PBS-1x e, a seguir, adicionou-se meio DMEM com $10 \%$ de FCS. Vinte e quatro horas após o início da transfecção as culturas tiveram o meio coletado e ultracentrifugados a $110.000 \times \mathrm{g}$ durante $90 \mathrm{~min}$, descartando-se o sobrenadante e o sedimento viral ressuspendido em Hank's salt solution (HBSS), mantido à $4^{\circ} \mathrm{C}$ por $16 \mathrm{~h}$, aliquotado e armazenado a $-70^{\circ} \mathrm{C}$. O meio das culturas foi reposto e depois de 24 h foi novamente coletado, ultracentrifugado, ressuspendido e armazenado a $-70^{\circ} \mathrm{C}$.

O primeiro teste utilizando vetor foi feito com $5 \times 10^{4}$ células incubadas com $7,5 \times 10^{5}$ partículas virais com uma multiplicidade de infecção (MOI) ${ }^{1}$ de 15 em $100 \mu \mathrm{L}$ de DMEM CULTIVO contendo $4 \mu \mathrm{g} / \mathrm{mL}$ de polibreno (Sigma) por $3 \mathrm{~h}$ a $37^{\circ} \mathrm{C}, 5 \% \mathrm{CO}_{2}$ em ar com alta umidade. Em seguida foram cultivadas em placas de seis cavidades contendo 1,5 mL de meio de cultivo sob as mesmas condições por mais $48 \mathrm{~h}$. As células foram lavadas 3 vezes em PBS e fixadas em solução de glutaraldeído 0,2\% $(\mathrm{v} / \mathrm{v})$, paraformaldeído $2 \%(\mathrm{~m} / \mathrm{v})$ e $0,1 \mathrm{M}$ fosfato de sódio monobásico $(\mathrm{pH}=7,3)$ a 4ํㅡ por 5 min. Após 2 lavagens em PBS, as células foram incubadas com o corante xgal (Anexo C) por $16 \mathrm{~h}$ a $37^{\circ} \mathrm{C}$. As células foram então examinadas em microscópio óptico (Olympus) para a visualização das células positivas (azuis) para expressão do gene LacZ.

\subsubsection{Injeção de corante azul de tripan em testículos de bovinos adultos}

Para a padronização do transplante das células espermatogoniais, testículos $(n=15)$ coletados de animais destinados ao abate comercial (Frigorífico Angelelli, Piracicaba, SP) foram levados ao laboratório em recipiente térmico. Utilizou-se solução de azul de tripan ( $1 \mathrm{mg} / \mathrm{mL}$ em solução salina) para a padronização da injeção da solução de células durante o transplante. Com auxílio da ultrassonografia, com probe de $5 \mathrm{MHz}$ (Piemedical), o mediastino foi localizado com imagens obtidas

1 Define-se por MOI (do inglês multiplicity of infection) a razão dada entre o número de partículas virais e células transduzidas. No caso de um $\mathrm{MOI}=15$, entende-se que foram utilizadas 15 partículas virais para cada célula durante a transdução. 
nos planos sagitais caudo-cranial e latero-lateral. Ainda com auxílio de imagem ultrassonográfica, uma agulha $(25 \times 10, B D)$ foi longitudinalmente introduzida ao testículo, lateralmente à cauda do epidídimo. Após alcançar o mediastino, $5 \mathrm{~mL}$ da solução de azul de tripan foram injetados lentamente, sendo a infusão do líquido observada por ultrassom durante a injeção. Ao término da injeção, os testículos foram incisados longitudinalmente e foi verificada a localização do corante azul de tripan em relação ao mediastino.

\subsubsection{Verificação da expressão de alfa-6 integrina antes e após purificação por gradiente de percoll}

Para verificação da quantidade de SSCs presente na população de células espermatogoniais após purificação por gradiente descontínuo de Percoll, foi realizada análise da expressão do marcador alfa-6 integrina por citometria de fluxo e RT-PCR em tempo real.

Para avaliação por citometria de fluxo, foram isoladas células de 6 testículos conforme descrito no item 4.1.1. Após o isolamento, as células foram submetidas ao plaqueamento diferencial (item 4.1.2.1) e ao gradiente descontínuo de Percoll (item 4.1.2.2). Amostras de $1 \times 10^{6}$ células foram fixadas em etanol $70 \%(\mathrm{v} / \mathrm{v})$ gelado $\left(4^{\circ} \mathrm{C}\right)$ antes e após a purificação com gradiente de Percoll. Foram coletadas amostras das quatro frações após a centrifugação com Percoll (Item 4.1.2.2; Figura 3). As células fixadas foram incubadas com o anticorpo anti-alfa-6 integrina e analisadas por citometria de fluxo conforme descrito no item 4.1.3.1. A porcentagem de células positivas para marcação com anticorpo anti-alfa-6 integrina foi analisada por ANOVA (LSD) pelo programa Statistica for Windows, utilizando o nível de significância de $5 \%$. Foi considerada como variável independente a fração de células (0: antes do gradiente de Percoll; 1-4: após gradiente de Percoll) e como variável dependente a porcentagem de células positivas para marcação com 0 anticorpo anti-alfa-6 integrina.

Para a avaliação por RT-PCR em tempo real, foram isoladas células de 3 testículos conforme descrito no item 4.1.1. Após o isolamento, as células foram 
submetidas ao plaqueamento diferencial (item 4.1.2.1) e ao gradiente descontínuo de Percoll (item 4.1.2.2). Amostras de $1 \times 10^{6}$ células foram congeladas em nitrogênio líquido antes e após a purificação. Foram coletadas amostras das quatro frações após a centrifugação com Percoll (Item 4.1.2.2; Figura 3). As amostras congeladas foram processadas e avaliadas por RT-PCR em tempo real para verificação da expressão do marcador alfa-6 integrina, conforme descrito no item 4.1.3.3. A análise estatística dos dados foi feita utilizando-se o método Pfaffl, onde eficiências de amplificação dos primers determinadas experimentalmente são utilizadas para verificar a expressão do gene alvo (alfa-6 integrina ou ITGA6) em relação ao gene endógeno (beta actina ou ACTB).

\subsubsection{Estudo do perfil de expressão dos genes itga6, gfr-1 e pgp9.5 em células espermatogoniais antes e após plaqueamento diferencial}

Para a verificação do padrão de expressão dos genes ITGA6, GFRa-1 e PGP9.5 em células espermatogoniais antes (D0) e após o plaqueamento diferencial (D1), foram isoladas células de 10 testículos, conforme descrito no item 4.1.1. As células foram submetidas ao plaqueamento diferencial (item 4.1.2.1). Amostras de $1 \times 10^{6}$ células viáveis foram congeladas em nitrogênio líquido antes e após a purificação. As amostras congeladas foram processadas e avaliadas por RT-PCR em tempo real para verificação da expressão dos marcadores ITGA6, GFRa-1 e PGP9.5, conforme descrito no item 4.1.3.3. A análise estatística dos dados foi feita pelo método Pfaffl, no qual eficiências de amplificação dos primers determinadas experimentalmente são utilizadas para verificar a expressão dos genes alvos (ITGA6, GFRa-1 e PGP9.5) em relação aos genes endógenos (GAPDH e ACTB). 


\subsection{RESULTADOS}

\subsubsection{Isolamento de células espermatogoniais de bovinos adultos}

Foram realizadas 29 manipulações para a padronização do isolamento de SSC a partir de testículos de matadouro e as demais empregadas neste trabalho (Quadro 2). Durante a padronização do isolamento das SSC bovinas, foram obtidas em média $2,76 \times 10^{6} \pm 7,51 \times 10^{5}$ (média \pm erro padrão da média ou SEM, do inglês standard error of the mean) células espermatogoniais viáveis por grama de tecido processado.

Quadro 2 - Resumo das manipulações realizadas para isolamento de SSC bovinas

\begin{tabular}{|c|c|c|c|c|}
\hline Manipulação & Data & Massa testicular $(\mathbf{g})$ & $\begin{array}{c}\text { Células viáveis } \\
\text { (total) }\end{array}$ & $\begin{array}{c}\text { Células/g tecido } \\
\text { testicular }\end{array}$ \\
\hline 1 & $01 / 10 / 2009$ & 2,67 & $2,40 \mathrm{E}+06$ & $8,99 \mathrm{E}+05$ \\
\hline 2 & $13 / 10 / 2009$ & 15,50 & $2,30 \mathrm{E}+07$ & $1,48 \mathrm{E}+06$ \\
\hline 3 & $03 / 03 / 2009$ & 9,00 & $3,00 \mathrm{E}+06$ & $3,33 \mathrm{E}+05$ \\
\hline 4 & $11 / 08 / 2010$ & 28,00 & $4,20 \mathrm{E}+07$ & $1,50 \mathrm{E}+06$ \\
\hline 5 & $18 / 08 / 2010$ & 17,28 & $5,50 \mathrm{E}+07$ & $3,18 \mathrm{E}+06$ \\
\hline 6 & $22 / 09 / 2010$ & 26,50 & $3,53 \mathrm{E}+07$ & $1,33 \mathrm{E}+06$ \\
\hline 7 & $08 / 02 / 2011$ & 7,75 & $9,12 \mathrm{E}+06$ & $1,18 \mathrm{E}+06$ \\
\hline 8 & $08 / 02 / 2011$ & 8,98 & $4,83 \mathrm{E}+06$ & $5,38 \mathrm{E}+05$ \\
\hline 9 & $08 / 02 / 2011$ & 8,99 & $8,10 \mathrm{E}+06$ & $9,01 \mathrm{E}+05$ \\
\hline 10 & $15 / 02 / 2011$ & 12,55 & $8,95 \mathrm{E}+06$ & $7,13 \mathrm{E}+05$ \\
\hline 11 & $15 / 02 / 2011$ & 11,28 & $7,85 \mathrm{E}+06$ & $6,96 \mathrm{E}+05$ \\
\hline 12 & $15 / 02 / 2011$ & 12,26 & $8,45 \mathrm{E}+06$ & $6,89 \mathrm{E}+05$ \\
\hline 13 & $16 / 02 / 2011$ & 11,67 & $5,54 \mathrm{E}+07$ & $4,75 \mathrm{E}+06$ \\
\hline 14 & $16 / 02 / 2011$ & 12,26 & $4,06 \mathrm{E}+07$ & $3,31 \mathrm{E}+06$ \\
\hline 15 & $29 / 03 / 2011$ & 22,27 & $7,20 \mathrm{E}+06$ & $3,23 \mathrm{E}+05$ \\
\hline 16 & $06 / 04 / 2011$ & 34,55 & $2,00 \mathrm{E}+06$ & $5,79 \mathrm{E}+04$ \\
\hline 17 & $11 / 04 / 2011$ & 12,12 & $1,40 \mathrm{E}+06$ & $1,16 \mathrm{E}+05$ \\
\hline 18 & $27 / 04 / 2011$ & 21,00 & $6,20 \mathrm{E}+06$ & $2,95 \mathrm{E}+05$ \\
\hline 19 & $03 / 05 / 2011$ & 8,32 & $1,26 \mathrm{E}+07$ & $1,51 \mathrm{E}+06$ \\
\hline 20 & $03 / 05 / 2011$ & 12,25 & $1,40 \mathrm{E}+07$ & $1,14 \mathrm{E}+06$ \\
\hline 21 & $03 / 05 / 2011$ & 10,97 & $9,80 \mathrm{E}+06$ & $8,93 \mathrm{E}+05$ \\
\hline 22 & $10 / 05 / 2011$ & 6,09 & $2,17 \mathrm{E}+07$ & $3,56 \mathrm{E}+06$ \\
\hline 23 & $10 / 05 / 2011$ & 5,07 & $1,71 \mathrm{E}+07$ & $3,37 \mathrm{E}+06$ \\
\hline 24 & $17 / 05 / 2011$ & 4,22 & $9,00 \mathrm{E}+07$ & $2,13 \mathrm{E}+07$ \\
\hline 25 & $17 / 05 / 2011$ & 3,57 & $2,70 \mathrm{E}+07$ & $7,56 \mathrm{E}+06$ \\
\hline 26 & $17 / 05 / 2011$ & 3,92 & $1,70 \mathrm{E}+07$ & $4,34 \mathrm{E}+06$ \\
\hline 27 & $17 / 05 / 2011$ & 3,52 & $1,75 \mathrm{E}+07$ & $4,97 \mathrm{E}+06$ \\
\hline 28 & $23 / 05 / 2011$ & 7,70 & $3,40 \mathrm{E}+07$ & $4,42 \mathrm{E}+06$ \\
\hline 29 & $23 / 05 / 2011$ & 10,10 & $4,20 \mathrm{E}+07$ & $4,16 \mathrm{E}+06$ \\
\hline & & & & \\
\hline
\end{tabular}




\subsubsection{Purificação das SSCs de bovinos adultos}

\subsubsection{Plaqueamento diferencial}

Após o plaqueamento diferencial, notou-se que a população de células obtidas foi bastante heterogênea, observando células de tamanhos variados, além de espermatozoides (Figura 4)

Figura 4 - Fotografia representativa de células espermatogoniais bovinas, após 0 isolamento enzimático, obtida por microscopia óptica (Magnificação de 200 x). Células espermatogoniais de diferentes tamanhos (setas vermelhas) e espermatozoides (setas pretas)

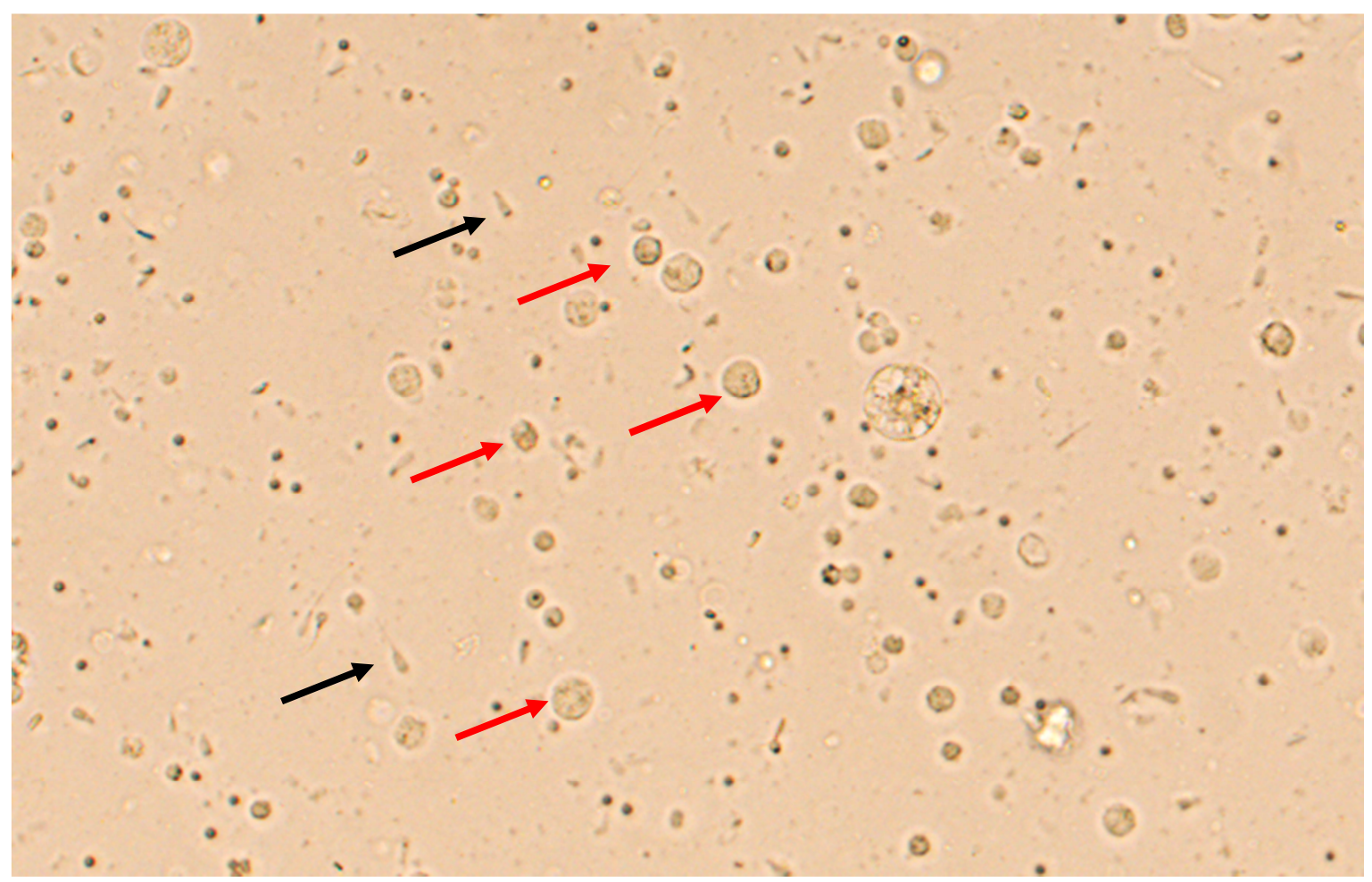


Para verificar o papel do plaqueamento diferencial na purificação das células espermatogoniais isoladas, foram comparadas as expressões de ITGA6, GFRa-1 e PGP9.5 em amostras coletadas logo após o isolamento enzimático (Do0) ou após o plaqueamento diferencial (D1; item 4.1.8). Não foi observada diferença na expressão dos três marcadores (ITGA: $p=0,908$, GFRa-1: $p=0,217$ e PGP9.5: $p=0,090$; Tabela 1).

Tabela 1 - Expressão relativa de ITGA6, GFRa-1 e PGP9.5 em células espermatogoniais antes (D0) e depois do plaqueamento diferencial (D1) - São Paulo - 2012

\begin{tabular}{cccccc}
\hline Gene & Tipo & $\begin{array}{c}\text { Expressão } \\
\text { D1/D0 }\end{array}$ & Erro Padrão & $\begin{array}{c}95 \% \text { Intervalo } \\
\text { de Confiança }\end{array}$ & $\mathrm{p}$ \\
\hline GAPDH & $\begin{array}{c}\text { Controle } \\
\text { Endógeno } \\
\text { Controle } \\
\text { Endógeno }\end{array}$ & 1,023 & 0,977 & & \\
ACTB & Alvo & 0,965 & $0,410-2,146$ & $0,186-3,762$ & 0,908 \\
ITGA6 & Alvo & 1,803 & $0,480-6,724$ & $0,177-22,903$ & 0,217 \\
GFR-1 & Alvo & 1,94 & $0,658-5,954$ & $0,310-15,624$ & 0,09 \\
PGP9.5 & & & & & \\
\hline
\end{tabular}

\subsubsection{Gradiente descontínuo de Percoll}

Somente as células em suspensão foram submetidas ao gradiente descontínuo de Percoll. Após o gradiente descontínuo de Percoll, observou-se grande inconstância na formação das frações 1-4. Além disso, a quantidade de células recuperadas foi bastante baixa. Assim, para verificar a eficiência do gradiente de Percoll na purificação das SSCs bovinas, verificou-se a expressão de alfa-6 integrina das células espermatogoniais antes e após purificação por gradiente de Percoll por citometria de fluxo e por RT-PCR em tempo real (item 4.1.7).

Não foi observada diferença na expressão deste marcador quando as células foram avaliadas por citometria de fluxo ( $p=0,5636$; Figura 5 e Figura 6$)$. Também não 
foi observada diferença na expressão deste marcador quando as células foram avaliadas por RT-PCR em tempo real ( $p>0,05$; Tabela 2).

Figura 5 - Gráfico das porcentagens de células espermatogoniais expressando alfa-6 integrina, analisadas por citometria de fluxo, antes (Fração 0) e depois da purificação com gradiente descontínuo de Percoll (Frações 1-4; Média dos quadrados mínimos + EPM)
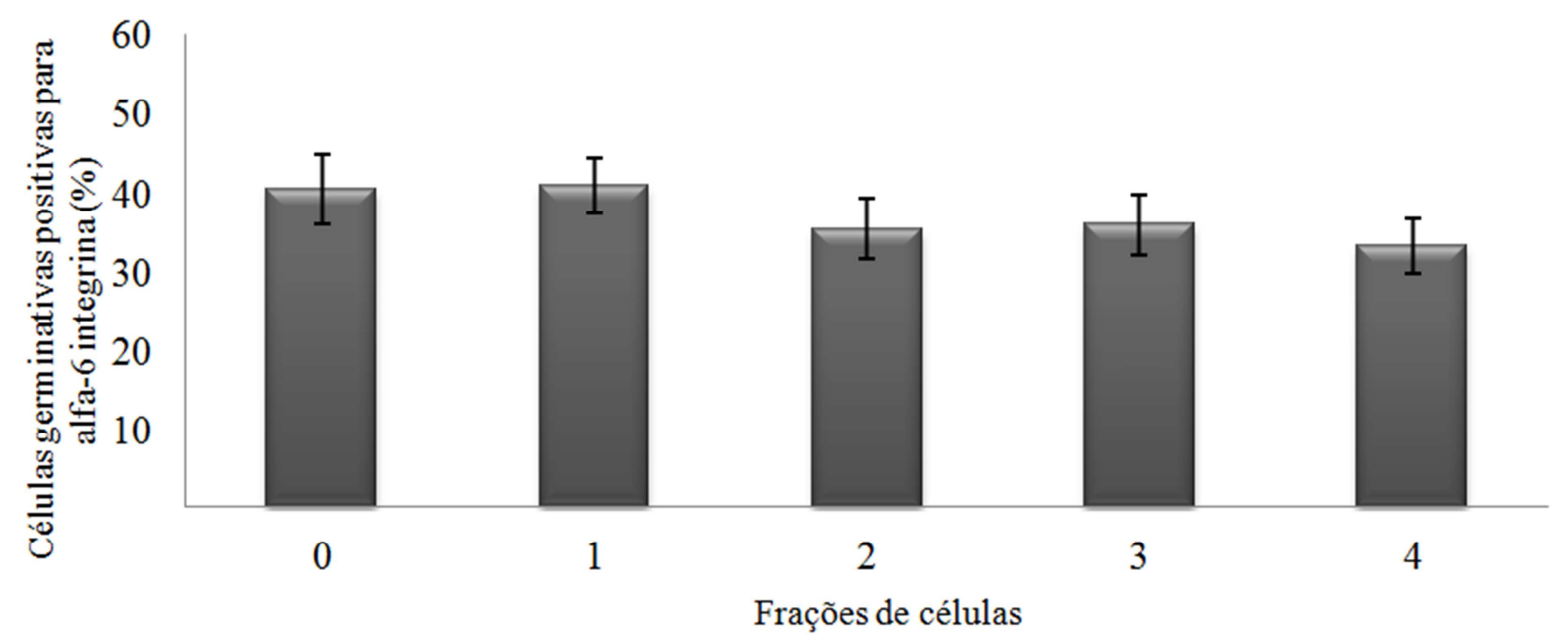

Figura 6 - Gráfico da expressão de alfa- 6 integrina em células espermatogoniais. Histogramas ilustrativos de florescência verde (alfa-6 integrina; preto) contra fluorescência vermelha (PI; cinza) antes (F0) e depois da purificação com gradiente de Percoll (F1-F4)
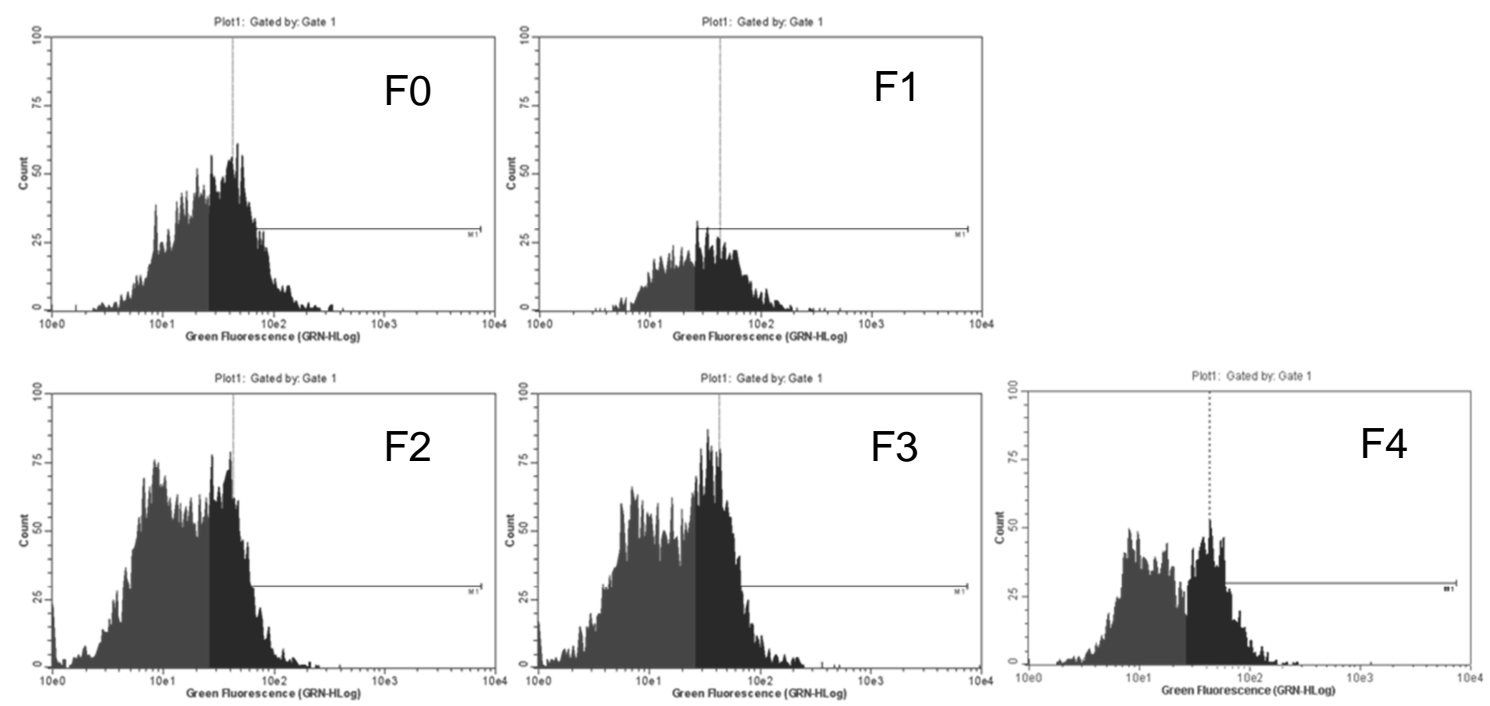
Tabela 2 - Comparação da expressão de ITGA6 entre amostras coletadas antes (F0) e depois da purificação com gradiente descontínuo de Percoll (F1-4) avaliadas por RT-PCR em tempo real - São Paulo - 2012

\begin{tabular}{c|ccccc}
\hline $\mathrm{p}$ & F0 & F1 & F2 & F3 & F4 \\
\hline F0 & & 0.947 & 0.493 & 0.947 & 0.946 \\
F1 & 0.947 & & 0.799 & 0.944 & 0.948 \\
F2 & 0.493 & 0.799 & & 0.893 & 0.957 \\
F3 & 0.947 & 0.944 & 0.893 & & 0.951 \\
F4 & 0.946 & 0.948 & 0.957 & 0.951 & \\
\hline
\end{tabular}

\subsubsection{Caracterização das células espermatogoniais de bovinos adultos}

4.2.3.1 Detecção da expressão de alfa-6 integrina e afinidade pela lectina DBA por citometria de Fluxo

Foi detectada a expressão de alfa- 6 integrina nas amostras de células espermatogoniais avaliadas por citometria de fluxo (Figura 7).

Foi possível verificar afinidade das células espermatogoniais utilizando incubação com lectina DBA, avaliada por citometria de fluxo (Figura 8). 
Figura 7 -Gráfico da expressão de alfa-6 integrina em células espermatogoniais bovinas avaliadas por citometria de fluxo. Eixo y: fluorescência verde (FITC) e eixo x: tamanho celular. Em (A) observa-se uma amostra positiva para expressão de alfa-6 integrina e em (B) o controle negativo da reação
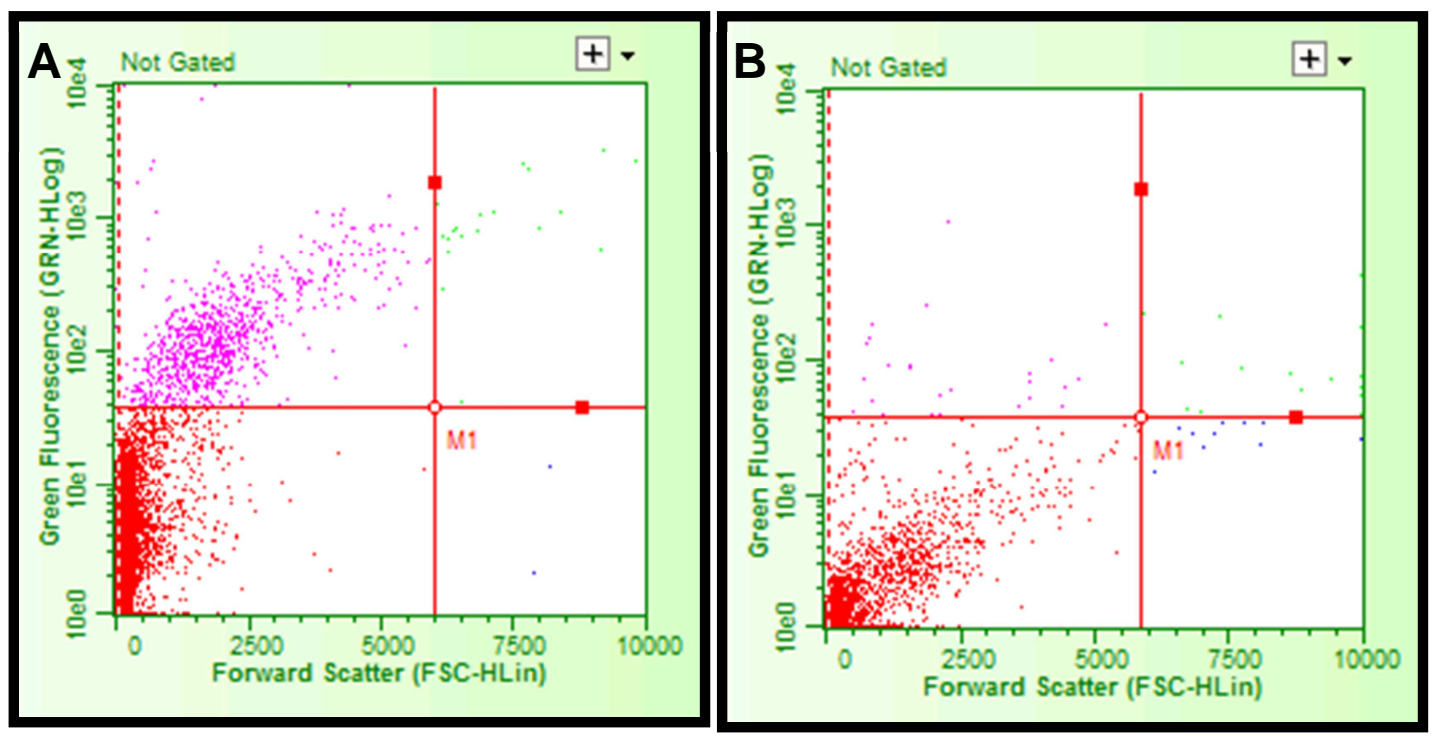

Figura 8 - Gráfico da afinidade das células espermatogoniais bovinas pela lectina DBA avaliadas por citometria de fluxo. Eixo y: fluorescência verde (FITC) e eixo $x$ : tamanho celular. Em (A) observa-se uma amostra positiva para marcação com DBA e em (B) o controle negativo da reação
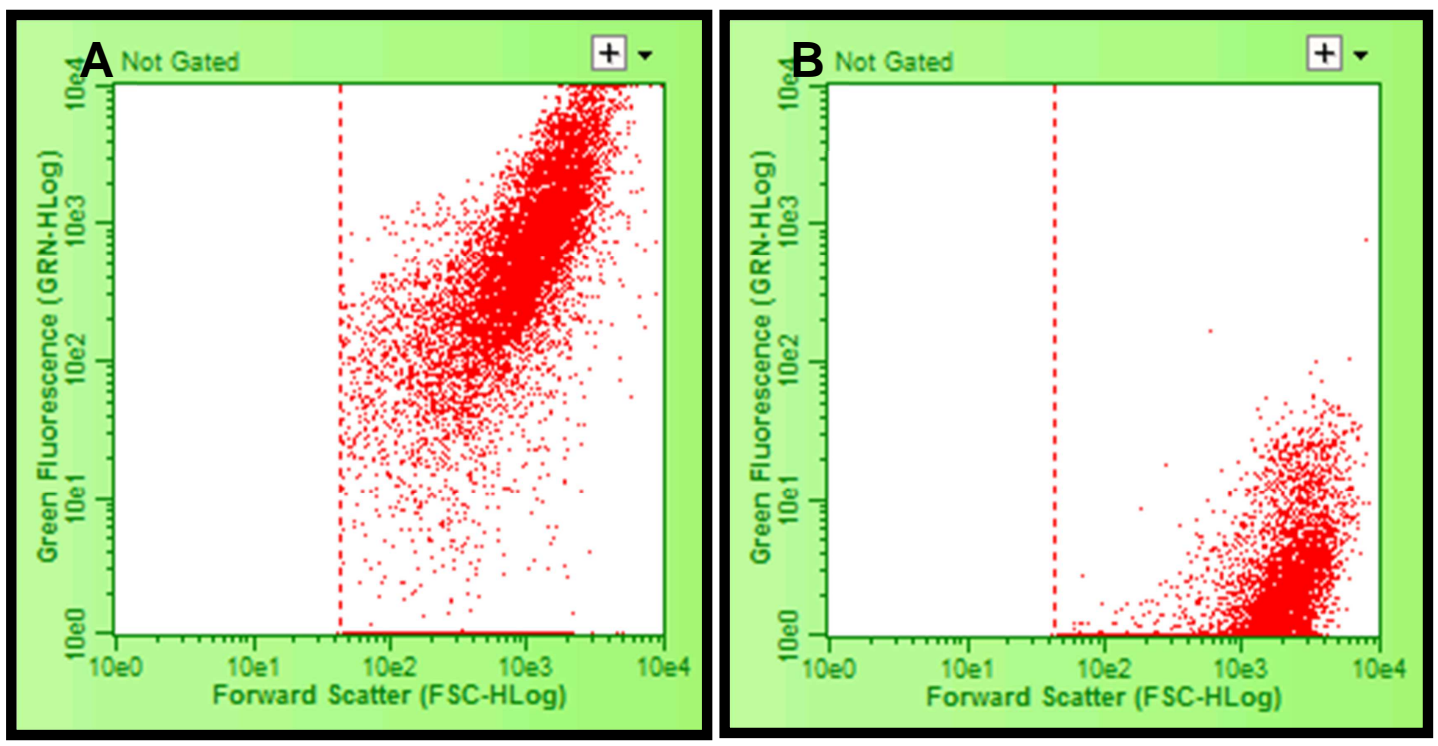
4.2.3.2 Deteção da expressão de PGP9.5 por reação de imunofluorescência em células espermatogoniais de bovinos adultos

Foi verificada a expressão de PGP9.5 por imunocitoquímica em células espermatogoniais (Figura 9).

Figura 9 - Fotografia da reação de imunocitoquímica de células espermatogoniais bovinas para verificação da expressão de PGP9.5. (A) Núcleo celular marcado com Hoechst 33342, (B) células positivas para expressão de PGP9.5 (verde, FITC) e (C) sobreposição das imagens A e B (magnificação de 200 x)

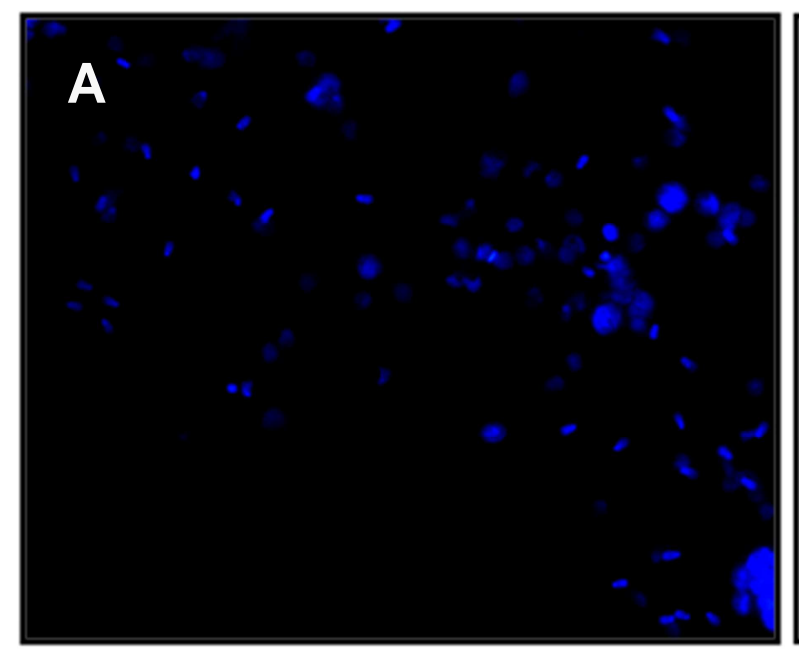

B

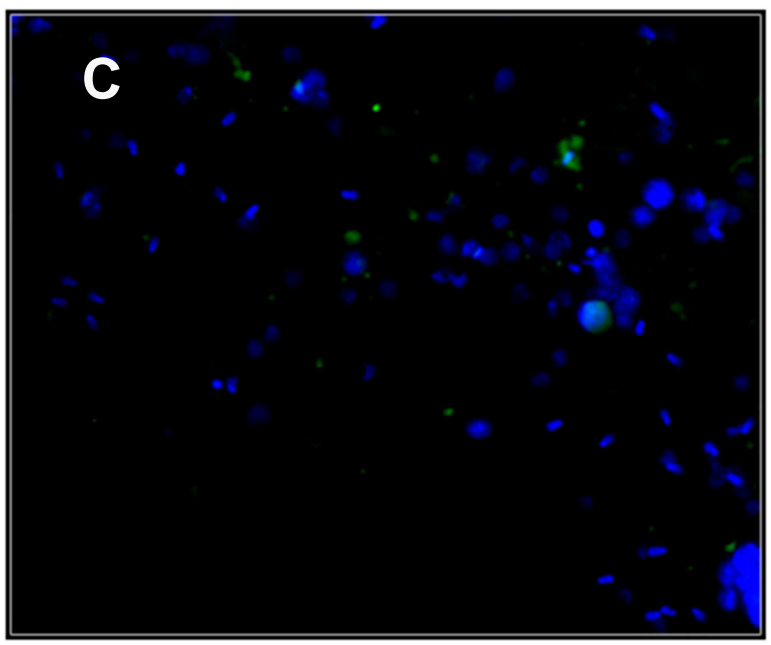


4.2.3.3 Expressão gênica dos marcadores ITGA6, GFRa-1 e PGP9.6 em células espermatogoniais de bovinos adultos

Foi realizada a avaliação da expressão gênica por RT-PCR em tempo real dos marcadores ITGA6, GFRa-1 e PGP9.5 (item 4.1.3.3) em células espermatogoniais bovinas (item 4.1.1). Foi detectada a expressão dos genes estudados em todas as amostras. A Figura 10 ilustra o perfil de expressão destes três marcadores.

Figura 10 - Gráfico da expressão relativa dos genes ITGA6, GFRa-1 e PGP9.5 em células espermatogoniais de bovinos adultos avaliada por reação de RT-PCR em tempo real

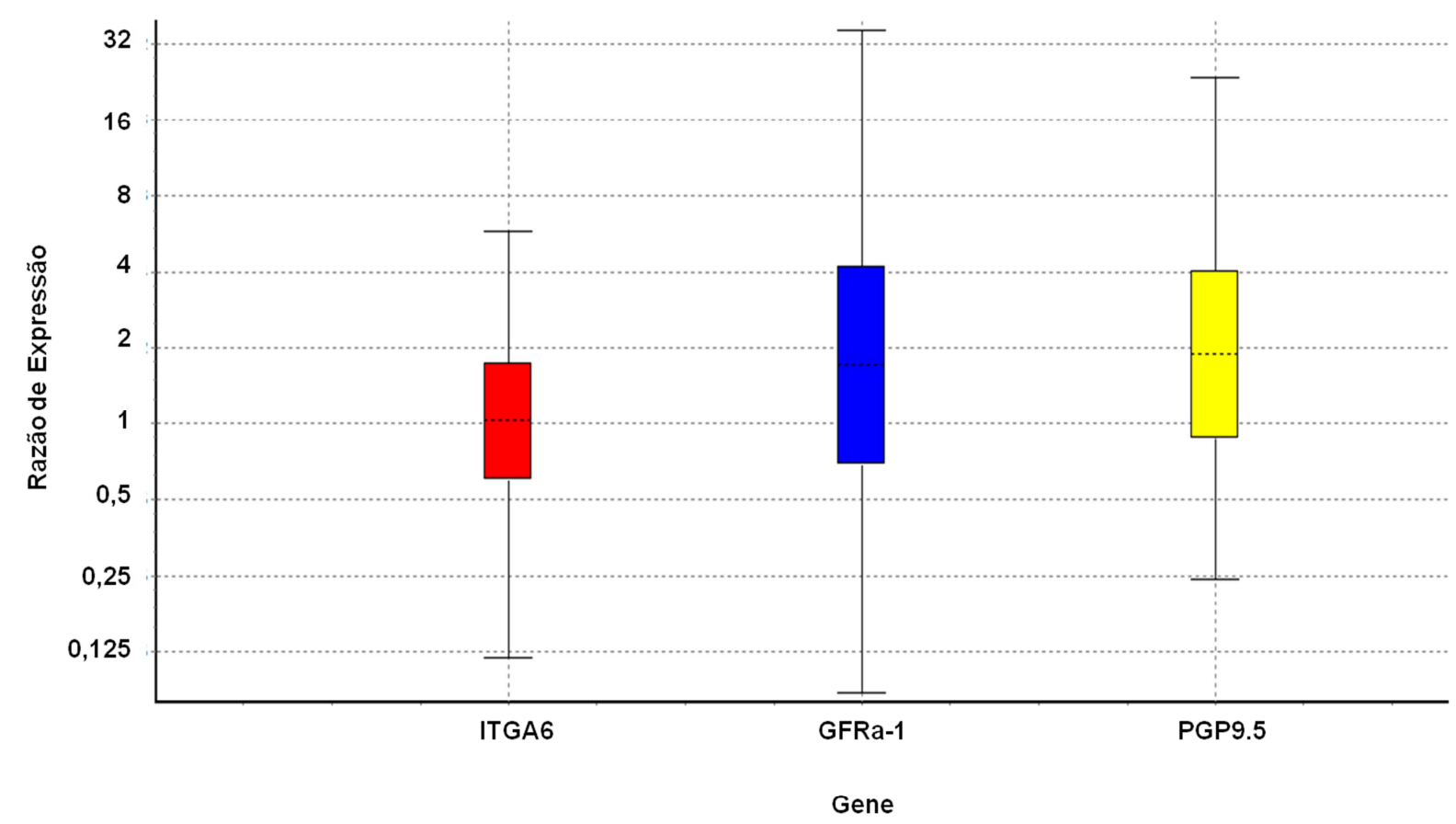

\subsubsection{Marcação das células espermatogoniais de bovinos adultos com PKH26}

A incubação de células espermatogoniais com corante de rastreamento celular na concentração sugerida pelo fabricante foi realizada com sucesso. $O$ 
quadro 3 mostra as porcentagens de células marcadas pelo corante após a incubação e avaliação por citometria de fluxo.

Quadro 3 - Porcentagem de células marcadas com PKH26 e analisadas por citometria de fluxo

\begin{tabular}{|c|c|c|}
\hline Amostras & Células Marcadas (\%) & Células não Marcadas (\%) \\
\hline PKH26+ & 97,88 & 2,12 \\
\hline PKH26- & 0,67 & 99,33 \\
\hline PKH26+/ PKH26- & 40,95 & 59,05 \\
\hline
\end{tabular}

A Figura 11 ilustra células espermatogoniais adultas incubadas com corante de rastreamento celular $\mathrm{PKH} 26$.

Figura 11 - Fotografia de microscopia de epifluorescência com filtro para rodamina de células espermatogoniais incubadas com PKH26 (200x)

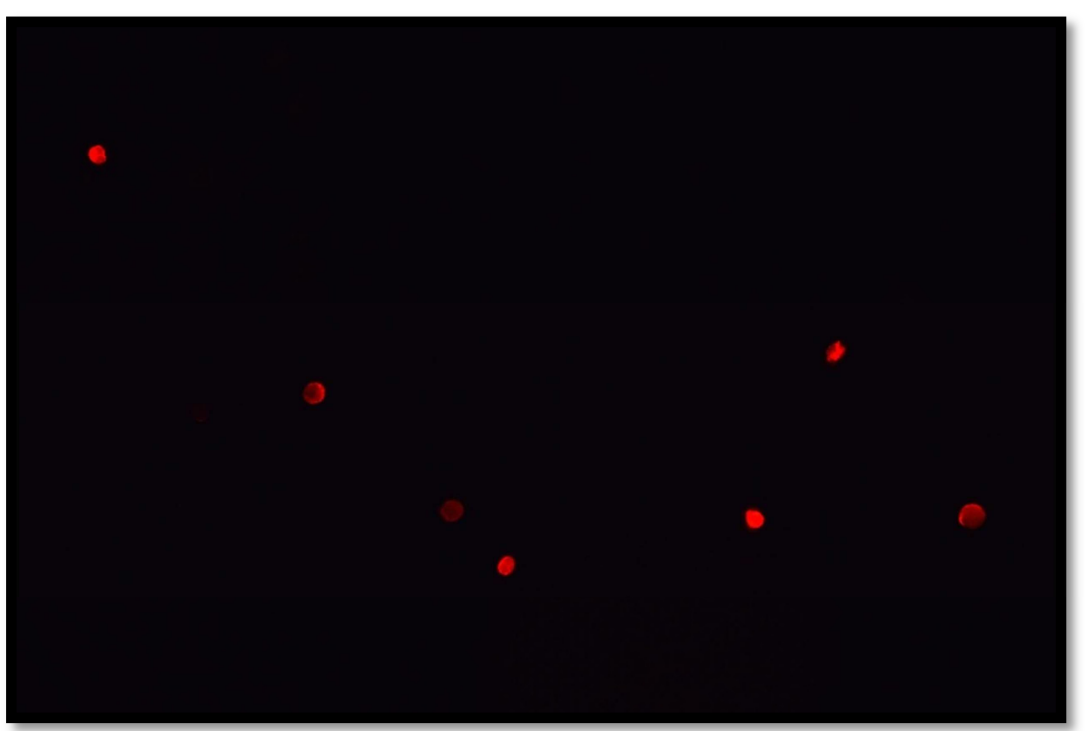




\subsubsection{Transformação das células espermatogoniais de bovinos adultos}

A transdução com LacZ foi verificada por reação com X-gal, observando células LacZ+ coradas em azul (Figura 12).

Figura 12 - Fotografia de (A) células espermatogoniais bovinas adultas expressando betagalactosidase após transdução com vetor lentiviral pLV-Lacz e (B) controle negativo (magnificação de $400 \mathrm{x}$ )

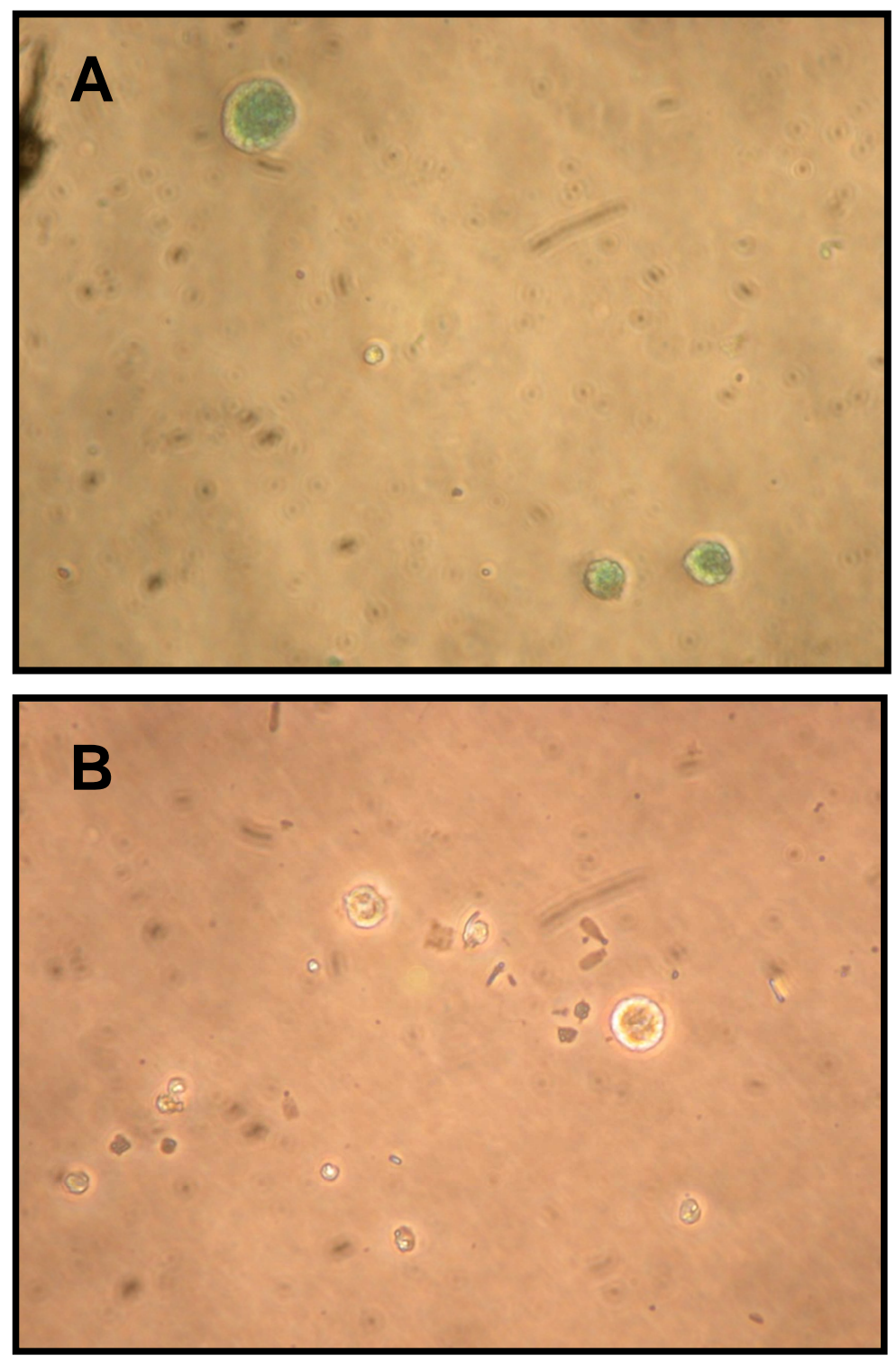




\subsubsection{Injeção de corante azul de tripan em testículos de bovinos adultos}

A ultrassonografia possibilitou a visualização do mediastino de todos os testículos que receberam a injeção. A injeção foi realizada com sucesso em 9 de 15 testículos observando a distribuição do corante ao longo do mediastino. A injeção guiada por ultrassonografia foi considerada insatisfatória quando o corante ficou confinado em ponto específico, fora do mediastino, de 6 testículos. A Figura 13 ilustra dois exemplos de testículos após a injeção de azul de tripan guiada por ultrassonografia, na qual observa-se a distribuição do corante no mediastino $(A)$ e o confinamento em um único ponto $(B)$.

Figura 13 - Fotografia de testículos bovinos oriundos de abatedouro comercial após injeção de $5 \mathrm{~mL}$ do corante azul de tripan guiada por ultrassonografia. Em (A) observa-se a distribuição do corante no mediastino e em (B) o confinamento do corante em um único ponto

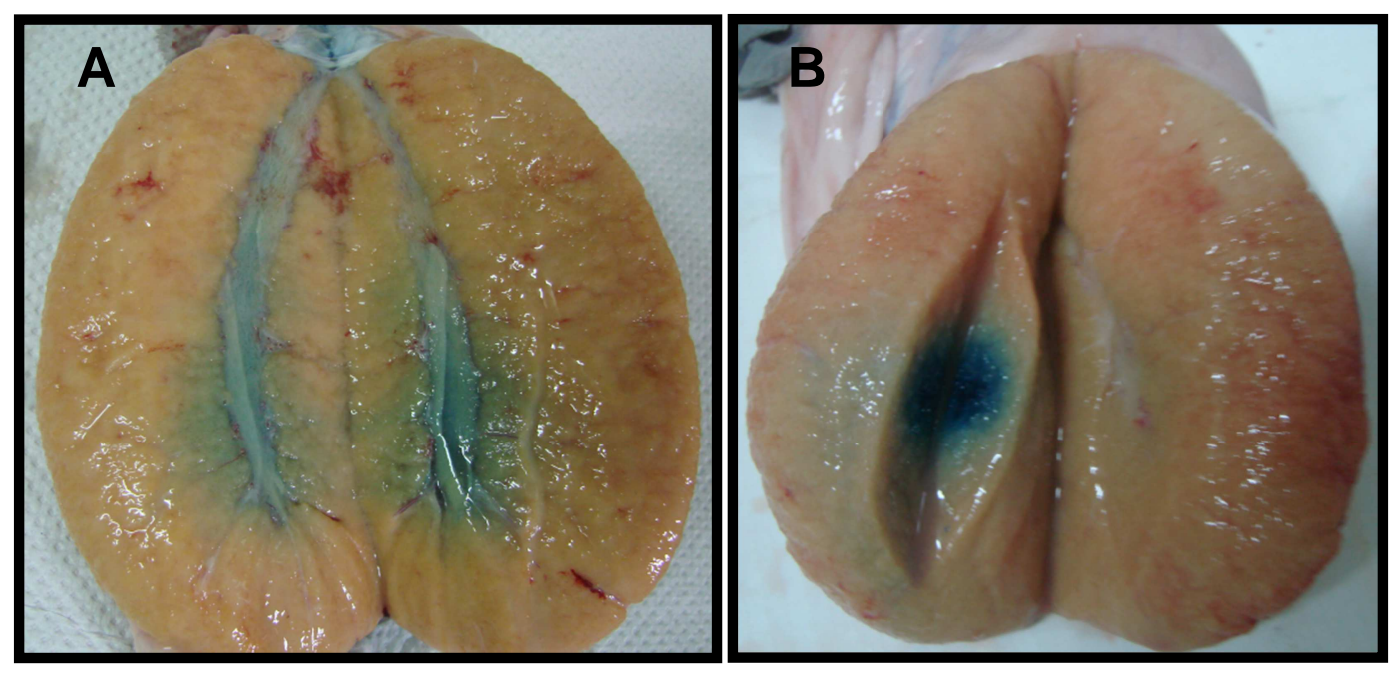




\subsection{DISCUSSÃO}

Para o desenvolvimento e padronização das técnicas de isolamento, cultivo in vitro, caracterização celular, modificação genética e transplante de SSCs foram utilizados testículos de touros abatidos comercialmente. Tendo em vista as variáveis inerentes à origem dos testículos de abatedouros, o procedimento adotado para o isolamento das SSC foi realizado de maneira padrão em todas as manipulações. Mesmo assim, ao longo das repetições deste processo, observou-se grande variação na quantidade de células por grama de tecido testicular digerido. Essa variação pode ser atribuída à variação individual, sendo que não houve controle da idade, raça ou escore corporal dos animais. Além disso, as condições de transporte como temperatura e tempo decorrido desde o abate e coleta dos testículos até o laboratório não se mantiveram constantes. Apesar das desvantagens observadas no isolamento de células espermatogoniais de testículos oriundos de animais abatidos comercialmente, sua utilização forneceu material em abundância para o estabelecimento das técnicas citadas no início deste parágrafo, fundamentais para a concretização do objetivo proposto. Embora variável, a quantidade mínima de células (aproximadamente $1 \times 10^{5}$ células/ $\mathrm{g}$ de tecido testicular) se mostrou satisfatória.

Após o plaqueamento diferencial, duas populações morfologicamente distintas puderam ser observadas em microscopia óptica. As células aderidas apresentaram morfologia semelhante à células de Sertoli, formando monocamadas de células características deste tipo celular (APONTE et al., 2006). Contudo, nenhum estudo foi realizado para confirmar a identidade das células aderidas à placa de Petri. Em função que células espermatogoniais permanecem em suspensão quando cultivadas in vitro, foi realizada a verificação da expressão dos marcadores ITGA6, GFR-1 e PGP9.5 somente das células não aderidas. Embora tenha sido detectada a expressão dos três marcadores, não foi observada diferença quantitativa na expressão destes genes antes (D0) ou após o plaqueamento diferencial (D1). Esses dados sugerem que o plaqueamento diferencial não isolou de maneira significativa a população de células espermatogoniais indiferenciadas. Visto que o mesmo número de células foi utilizado na extração de RNA total de todas as 
amostras, esperava-se obter expressão relativa mais alta destes marcadores em D1 em consequência à separação da linhagem somática da germinativa com esta técnica.

O gradiente descontínuo de Percoll realizado após o plaqueamento diferencial não purificou as células espermatogoniais em relação à expressão de alfa-6 integrina, avaliada por citometria de fluxo e RT-PCR em tempo real. Os resultados foram semelhantes ao observado por Herrid et al. (2009), quando verificaram que o gradiente de Percoll não ofereceu grande quantidade de SSCs do tipo A comparado às outras técnicas de purificação de SSCs, embora o marcador utilizado por Herrid e colaboradores tenha sido o DBA. Além disso, após a centrifugação com gradiente de Percoll, poucas células puderam ser recuperadas das fases compreendidas entre as camadas de Percoll. Esta baixa quantidade de células recuperadas é especialmente crítica para o sucesso deste trabalho, pois em seguida pretendia-se transformar as células com vetor lentiviral contendo a sequência do gene LacZ, uma etapa onde sabidamente muitas células morrem. Somadas as duas situações, estimou-se que não haveria células suficientes para o transplante. Diante disso, optou-se por não realizar a purificação das SSCs por gradiente descontínuo de Percoll, somada ao fato de que o Percoll pode alterar o perfil lipídico da membrana plasmática de espermatozoides (FURIMSKY et al., 2005). Assim, uma interação similar com a membrana plasmática das SSCs poderia diminuir a sobrevida in vitro e a viabilidade dessas células pré-transplante. Contudo, esta decisão trouxe uma implicação importante para este trabalho. Sem a etapa de purificação, realizou-se o transplante com uma população menos pura de SSCs em bezerros pré-púberes, descrito no Capítulo 2.

A primeira verificação de um suposto marcador de SSCs bovinas apresentou bons resultados. Pela primeira vez foi verificada a expressão da proteína alfa-6 integrina nas células. Sabe-se que as SSC encontram-se na membrana basal dos túbulos seminíferos e se proliferam lentamente para produzir SSC adicionais por auto-renovação e células progenitoras que se proliferam significantemente durante o processo de diferenciação até espermatozóides. Assim, dentre outros, a alfa-6 integrina tem sido utilizada como marcador para SSC de ratos e camundongos (SALANOVA et al., 1995; SHINOHARA; AVARBOCK; BRINSTER, 1999). Além disso, foi verificada a afinidade das células espermatogoniais isoladas pela lectina 
DBA em citometria de fluxo, assim como a presença de PGP9.5 por reação de imunofluorescência. Foi avaliada a expressão do suposto marcador ITGA6 e os marcadores GFRa-1 e PGP9.5, ambos já utilizados em SSCs desta espécie.

Segundo Herrid et al. (2007), a identificação das SSCs presentes na população de células a serem transplantadas representa um dos pontos críticos para o sucesso de seu transplante na espécie bovina. Contudo, a falta de marcadores confiáveis e a baixa concentração original destas células nos testículos têm dificultado a identificação e purificação das SSCs (DE KRETSER; KERR, 1994; SHINOHARA; AVARBOCK; BRINSTER, 2000). Espera-se, com o presente trabalho, contribuir para a identificação de SSCs bovinas.

Finalmente, adotou-se o termo "célula espermatogonial" ao invés de SSCs quando tratar-se das células já isoladas, pois sem a realização de uma etapa de purificação para remoção das células já diferenciadas, denominá-las categoricamente de SSC seria impreciso. 
CAPÍTULO 2:

CÉLULAS ESPERMATOGONIAIS BOVINAS LACZ+ PODEM INTECRAR-SE AOS TÚBULOS SEMINÍFEROS DE BEZERROS PRÉ-PÚBERES DA RAÇA NELORE APÓS TRANSPLANTE AUTÓLOGO? 


\section{CAPÍTULO 2: Células espermatogoniais bovinas LacZ+ podem integrar-se aos túbulos seminíferos de bezerros pré-púberes da raça Nelore após transplante autólogo?}

Para responder à questão "Células espermatogoniais bovinas LacZ+ podem integrar-se aos túbulos seminíferos de bezerros pré-púberes da raça Nelore após transplante autólogo?" foi realizado o experimento in vivo descrito a seguir.

\subsection{MATERIAIS E MÉTODOS}

\subsubsection{Animais e Manejo}

Foram utilizados 16 bezerros pré-púberes da raça Nelore (Bos taurus taurus, 4 meses de idade e peso vivo médio de $100 \mathrm{~kg}$ ) provenientes do rebanho do Sistema de Bovinocultura de Corte da Prefeitura da USP, Campus Pirassununga, Pirassununga, SP. As orquiectomias e os transplantes de SSCs foram realizados no Centro de Biotecnologia da Reprodução (CBRA) do Departamento de Reprodução Animal da FMVZ-USP, Campus Pirassununga. Por serem lactentes, os bezerros foram manejados junto às mães durante toda a experimentação. Os animais foram mantidos em regime de pastagem, em piquete, com bebedouro e suplementação com sal mineral oferecido em cocho.

Para os procedimentos de orquiectomia e transplante, nos quais foi necessária sedação e anestesia local, os animais foram submetidos à jejum hídrico e alimentar de 12 horas. Para isso, os animais foram separados na noite anterior aos procedimentos e mantidos em piquete do curral adjacente ao das respectivas mães. Quando da permanência das fêmeas no curral, água e feno de coast-cross foram 
oferecidos ad libitum. Após a realização da primeira orquiectomia e do transplante de SSCs, os bezerros foram transferidos de volta ao pasto com suas mães.

Ao final do período de experimentação todos os animais receberam uma aplicação de ivermectina (Ivomec, Merial, pour-on, $10 \mathrm{~mL}$ para cada $100 \mathrm{~kg}$ de peso vivo) e retornaram ao Sistema de Bovinocultura de Corte da CCPS. Após 45 dias os bezerros foram transferidos novamente para as instalações do CBRA e realizada a segunda orquiectomia para o estudo dos testículos transplantados. O manejo dos animais nesta segunda fase seguiu o mesmo protocolo adotado na primeira orquiectomia.

\subsubsection{Delineamento experimental}

Para responder à questão "Células-tronco espermatogoniais bovinas LacZ+ podem integrar-se aos túbulos seminíferos de bezerros pré-púberes da raça Nelore após transplante autólogo?" foi adotado um delineamento experimental fatorial $2 \times 2$, (SSCs transduzidas ou não com LacZ, com ou sem o corante PKH26; Figura 14). Assim, foram definidos os grupos 1 (LacZ+/PKH26+); 2 (LacZ+/PKH26-); 3 (LacZ/PKH26+) e 4 (LacZ-/PKH26-). O grupo LacZ+/PKH26+ recebeu injeção de SSCs $\mathrm{LacZ}+$ marcadas com o corante de rastreabilidade celular PKH26 $(n=4)$. Para verificar se houve efeito do corante, o grupo LacZ+/PKH26- recebeu transplante somente de células transduzidas com o vetor lentiviral $\operatorname{Lac} Z(n=4)$. Como controle do efeito isolado da transdução com LacZ, ao grupo LacZ-/PKH26+ foram administradas somente células coradas com PKH26 $(n=4)$. E, finalmente, como controle dos dois procedimentos com as SSCs transplantadas, o grupo LacZ/PKH26- $(n=4)$ recebeu uma injeção com células apenas cultivadas in vitro, sem nenhuma modificação genética ou incubação com corante. Os animais foram alocados aleatoriamente em cada um dos grupos experimentais. 
Figura 14 - Delineamento experimental fatorial $2 \times 2$ (SSCs transduzidas ou não com LacZ, marcadas ou não com o corante PKH26) para estudo da integração de SSCs bovinas LacZ+ após transplante autólogo

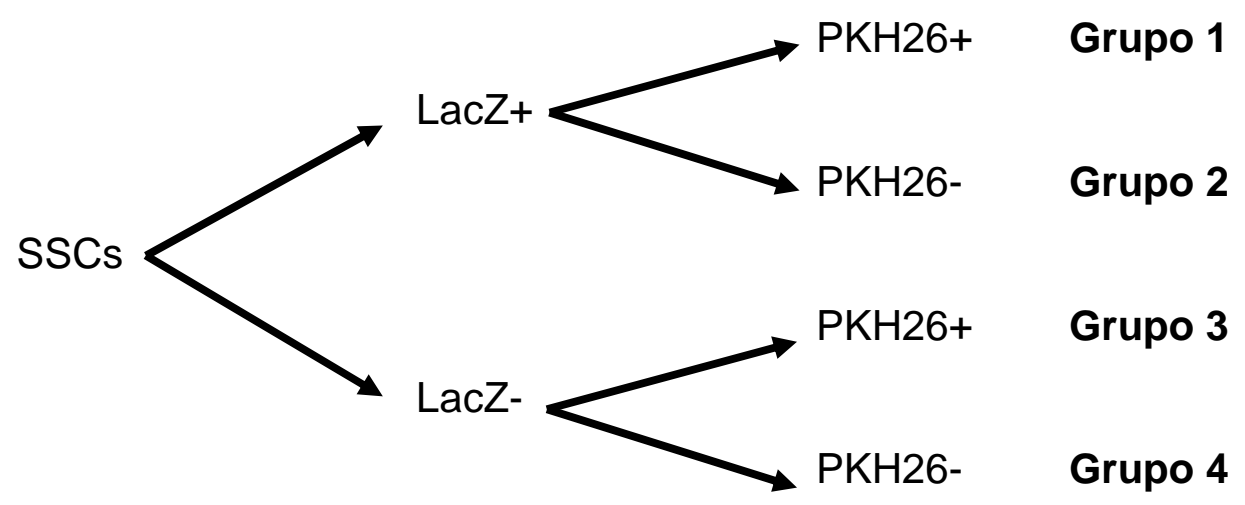

\subsubsection{Isolamento de células espermatogoniais de bovinos pré-púberes}

5.1.3.1 Orquiectomia unilateral do testículo doador

Os 16 bezerros foram divididos em 4 lotes com 4 animais, sendo que em cada lote foi alocado aleatoriamente um bezerro de cada grupo experimental. Apenas um lote foi submetido à orquiectomia unilateral por dia, no período da manhã, totalizando 4 dias consecutivos de castrações.

Após $12 \mathrm{~h}$ de jejum hídrico e alimentar, os animais foram sedados $(0,2 \mathrm{mg}$ de xilazina por quilograma de peso vivo IM, Anadesan, SESPO - Divisão Vetbrands Saúde Animal) e receberam anestesia local no cordão espermático $(5 \mathrm{~mL}$ de cloridrato de lidocaína 2\% sem vasoconstritor SC, Xylestesin 2\% sem vasoconstritor, Cristália). Foi realizada uma incisão de $2 \mathrm{~cm}$ látero-caudal na bolsa escrotal com auxílio de lâmina de bisturi número 22. A túnica vaginal parietal foi incisada lateralmente para a total exposição do testículo. O cordão espermático foi fixado com pinça hemostática para a realização da ligadura com fio de sutura sintético absorvível Vicryl. O cordão espermático foi incisado distalmente à ligadura para excisão do testículo. Foi aplicada tintura de iodo $10 \%$ (v/v) em álcool no local da 
ferida cirúrgica, seguida de antiparasitário em pó (Tanidil, Bayer). Os animais receberam pentabiótico [1 mL (187.500 e 62.500 UI de Benzil penicilina Procaína e Potássica $+100 \mathrm{mg}$ de Estreptomicina base) para cada $25 \mathrm{~kg}$ de peso vivo IM SID, Agrosil 5 Mega, Vansil Saúde Animal] por 3 dias. Os testículos foram imediatamente lavados em solução salina a $37^{\circ} \mathrm{C}$ e levados ao laboratório adjacente ao curral em saco plástico contendo salina a $37^{\circ} \mathrm{C}$.

\subsubsection{Coleta do tecido testicular}

Antes do início do processamento, os testículos foram novamente lavados em salina a $37^{\circ} \mathrm{C}$ e álcool $70 \%$ (v/v) no laboratório. Com auxílio de lâmina de bisturi número 22, foi realizada uma incisão longitudinal da túnica vaginal visceral e túnica albugínea. Todo o tecido testicular foi dissecado da túnica albugínea (Figura 15) e transferido para uma placa de Petri de $60 \mathrm{~mm}$, na qual a massa foi registrada com auxílio de balança semianalítica. Amostras de $125 \mathrm{~mm}^{3}$ foram coletadas com auxílio de pinça anatômica e tesoura cirúrgica e imediatamente colocadas em tubo cônico de centrífuga de $15 \mathrm{~mL}$ contendo $10 \mathrm{~mL}$ de solução fixadora metacarne $[60 \%(\mathrm{v} / \mathrm{v})$ de metanol, 30\%(v/v) de clorofórmio e 10\%(v/v) de ácido acético glacial], (3 fragmentos por tubo de $15 \mathrm{~mL}$ ). Após $24 \mathrm{~h}$ de fixação em metacarne, os fragmentos foram transferidos para tubo cônico de centrífuga de $15 \mathrm{~mL}$ contendo $10 \mathrm{~mL}$ de etanol $95 \%$ $(v / v)$. As amostras fixadas em metacarne foram utilizadas para verificar a expressão de PGP9.5 e a afinidade pelo DBA por reação de imunofluorescência. O restante do tecido foi imediatamente submetido à digestão enzimática. 
Figura 15 - Coleta de tecido de testículos de bezerros pré-púberes para isolamento de células espermatogoniais. (A) Incisão da túnica albugínea e (B) dissecção do parênquima testicular
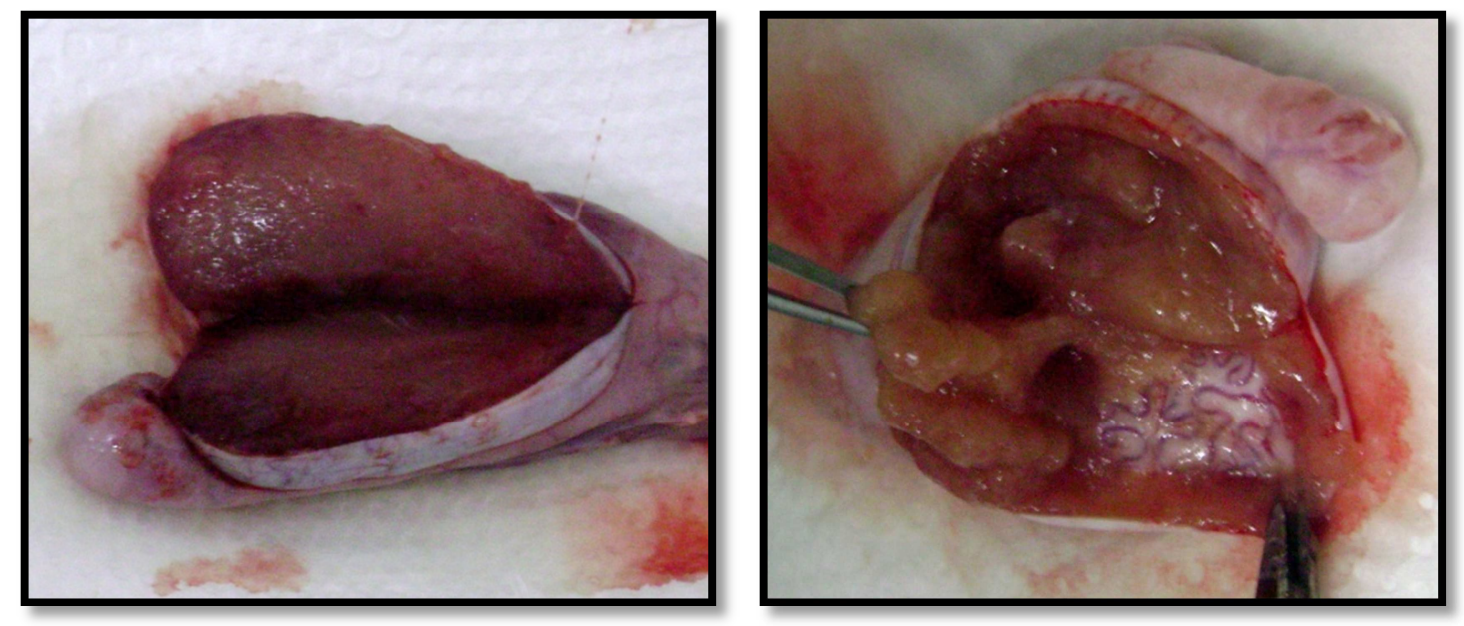

\subsubsection{Digestão enzimática}

Após o registro da massa, o tecido dissecado foi transferido para uma placa de Petri de vidro estéril de $35 \mathrm{~mm}$ e fragmentado com tesoura cirúrgica de ponta reta, em fluxo laminar vertical. Para o isolamendo de células espermatogoniais de bezerros pré-púberes, adotou-se um protocolo adaptado ao descrito por Reding e colaboradores (2010). Após obtenção de macerado homogêneo, o tecido foi transferido para um tubo cônico de centrífuga de $50 \mathrm{~mL}$ contendo $30 \mathrm{~mL}$ de meio DMEM Digestão 1, à base de colagenase (Anexo D). O tubo de digestão 1 foi incubado em banho-maria a $37^{\circ} \mathrm{C}$ por $30 \mathrm{~min}$, sendo homogeneizado manualmente (inversão do tubo 5 vezes) a cada $5 \mathrm{~min}$. O tecido digerido foi centrifugado a $50 \mathrm{xg}$ por 1 min e lavado 3 vezes em PBS a $37^{\circ} \mathrm{C}(50 \times \mathrm{g} / 1 \mathrm{~min}$ cada). Para a segunda digestão enzimática, o sedimento foi transferido para um tubo cônico de centrífuga de $50 \mathrm{~mL}$ contendo $30 \mathrm{~mL}$ DMEM Digestão 2, à base de tripsina (Anexo E) e incubado a $37^{\circ} \mathrm{C}$ em banho-maria por $5 \mathrm{~min}$. Para bloquear a ação da tripsina, foram adicionados 3,33 $\mathrm{mL}$ de FCS ao tubo de digestão 2. O conteúdo do tubo foi transferido para um filtro celular com malha de $100 \mu \mathrm{m}$ (Cell Strainer, BD) acoplado a um tubo cônico de centrífuga de $50 \mathrm{~mL}$ e centrifugado a $600 \times \mathrm{g}$ por $8 \mathrm{~min}$. $\mathrm{O}$ sobrenadante foi descartado e o sedimento lavado uma vez em PBS $(600 \times \mathrm{g} / 5$ 
min). As células isoladas foram ressuspendidas em $30 \mathrm{~mL}$ de DMEM contendo $0,2 \%$ de BSA (DMEM Cultivo BSA; Anexo F). Após a determinação da viabilidade e concentração celular pelo método de exclusão com azul de tripan e câmara de Neubauer, a concentração foi ajustada para $1 \times 10^{7}$ células viáveis/ $\mathrm{mL}$. As células foram cultivadas em placas de Petri de $100 \mathrm{~mm}\left(5 \times 10^{7}\right.$ células viáveis em $5 \mathrm{~mL}$ de DMEM Cultivo $\mathrm{BSA}$ ) a $37^{\circ} \mathrm{C}$ e $5 \%(\mathrm{v} / \mathrm{v})$ de $\mathrm{CO}_{2}$ em ar com alta umidade por $12-18 \mathrm{~h}$.

\subsubsection{Plaqueamento Diferencial}

Na manhã seguinte à digestão enzimática do tecido testicular, as células em suspensão foram transferidas para uma placa de Petri de $60 \mathrm{~mm}$ contendo DMEM Cultivo BSA. Esse procedimento é conhecido como plaqueamento diferencial, no qual as células somáticas se aderem à primeira placa de cultivo na incubação durante a noite (12-18 h), enquanto as células da linhagem germinativa permanecem em suspensão. A concentração das células em suspensão foi determinada pelo método de exclusão com azul de Tripan e ajustada para $1 \times 10^{6}$ células viáveis/ $\mathrm{mL}$, sendo cultivadas $5 \times 10^{6}$ células por placa de Petri de $60 \mathrm{~mm}(5 \mathrm{~mL}$ de DMEM Cultivo $B S A)$.

\subsubsection{Transdução das células espermatogoniais de bovinos pré-púberes com vetor LacZ}

A transdução das células espermatogoniais foi realizada $36 \mathrm{~h}$ após 0 isolamento enzimático. Somente células dos animais pertencentes aos grupos 1 e 2 foram submetidas a este procedimento. Para a modificação genética foi utilizado o vetor lentiviral LV-Lacz (Addgene) que contém a seqüência bacteriana LacZ que codifica a proteína beta-galactosidase. A produção dos vetores lentivirais foi realizada pela equipe do Prof. Dr. Bryam E. Strauss (Setor de Vetores Virais, Laboratório de Genética e Cardiologia Molecular, Instituto do Coração, InCor, FM- 
USP) e a transdução das células espermatogoniais de bezerros pré-púberes foi realizada no CBRA em Pirassununga. A produção das partículas virais foi realizada de acordo com o descrito no item 4.1.5, do Capítulo 1.

Para a transdução com 0 vetor, $1 \times 10^{6}$ células espermatogoniais viáveis pertencentes aos animais dos grupos 1 e 2 foram transferidas para microtubos de centrífuga de $1,7 \mathrm{~mL}$ e centrifugadas a $600 \times \mathrm{g}$ por $5 \mathrm{~min}$. $O$ sedimento foi ressuspendido em $1 \mathrm{~mL}$ de DMEM cultivo BSA fresco contendo $4 \mu \mathrm{g} / \mathrm{mL}$ de polibreno. Foram adicionadas $7,5 \times 10^{6}$ partículas virais $(\mathrm{MOl}=7,5)$ e a suspensão de células e partículas virais foi homogeneizada e transferida para 5 microtubos de centrífuga de $0,65 \mathrm{~mL}$ contendo $200 \mu \mathrm{L}$ desta suspensão em cada. Os microtubos foram incubados por $3 \mathrm{~h}$ a $37^{\circ} \mathrm{C}, 5 \% \mathrm{CO}_{2}$ em ar com alta umidade. Em seguida, as células transduzidas dos 5 microtubos foram transferidas para uma placa de Petri de $35 \mathrm{~mm}$ contendo $2 \mathrm{~mL}$ de DMEM Cultivo e incubadas por mais $21 \mathrm{~h}$ a $37^{\circ} \mathrm{C}, 5 \% \mathrm{CO}_{2}$ em ar com alta umidade. As células transduzidas permaneceram na incubadora de $\mathrm{CO}_{2}$ até o momento do transplante, realizado $60 \mathrm{~h}$ após o isolamento enzimático.

\subsubsection{Preparo das células espermatogoniais para o transplante}

Imediatamente antes do transplante autólogo $(60 \mathrm{~h}$ após 0 isolamento enzimático), células espermatogoniais pertencentes aos animais dos grupos 1 e 3 (PKH26+) foram incubadas com o corante de rastreamento celular $\mathrm{PKH} 26$ (Invitrogen). Assim, $1 \times 10^{6}$ células viáveis foram incubadas com o corante $\mathrm{PKH} 26$ $(2 \mu \mathrm{M})$ por $3,5 \mathrm{~min}$ a $25^{\circ} \mathrm{C}$. Em seguida, a suspensão de células com o corante foi incubada com $1 \mathrm{~mL}$ de FCS por 1 min para o bloqueio da marcação com o corante $e$ lavadas com $1 \mathrm{~mL}$ DMEM cultivo BSA. Após serem centrifugadas a $400 \times \mathrm{g}$ por $5 \mathrm{~min}$, as células foram ressuspendidas em PBS. O volume de PBS utilizado para cada animal variou de acordo com a massa do testículo doador. Para manter a proporção entre volume injetado e massa testicular em todos os animais, adotou-se o volume de $100 \mu \mathrm{L}$ de PBS por grama de tecido do testículo doador. Vale ressaltar que para isto foram consideradas semelhantes as massas dos testículos doador e receptor. 
Células espermatogoniais $\left(1 \times 10^{6}\right.$ células viáveis) pertencentes aos animais dos grupos 2 e 4 (PKH26-) não foram submetidas à incubação com o corante PKH26, sendo somente lavadas $1 \times$ em DMEM Cultivo BSA (400 x g por 5 min) e ressuspendidas em PBS, como descrito para os grupos 1 e 3 .

Após serem ressuspendidas em PBS, as células foram transferidas para seringas de $3 \mathrm{~mL}$ (BD) acopladas a agulhas descartáveis (40x8; BD) que foram mantidas a $37^{\circ} \mathrm{C}, 5 \% \mathrm{CO}_{2}$ em ar com alta umidade até o momento do transplante (Figura 16).

Figura 16 - Seringas contendo $1 \times 10^{6}$ células espermatogoniais em PBS, mantidas a $37^{\circ} \mathrm{C}, 5 \% \mathrm{CO}_{2}$ em ar com alta umidade até o momento do transplante. Os números correspondem ao número do animal ao qual pertencem as células

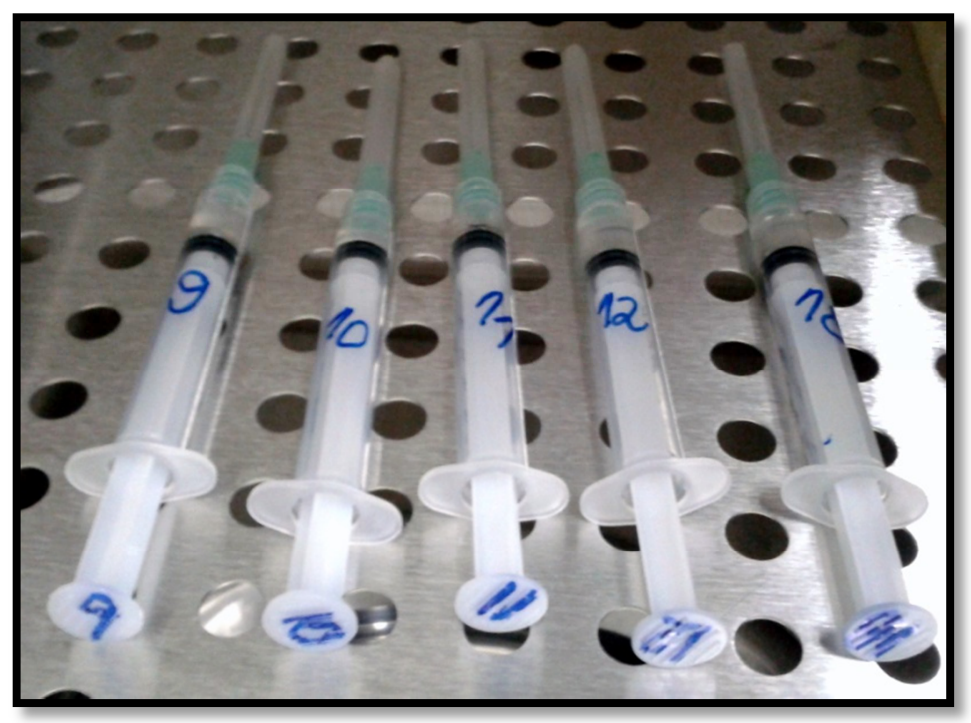

\subsubsection{Transplante autólogo de células espermatogoniais de bovinos pré- púberes}

O transplante autólogo de células espermatogoniais bovinas foi realizado $60 \mathrm{~h}$ após o início do experimento (isolamento enzimático). Para isso, os animais correspondentes às células a serem transplantadas foram contidos e receberam anestesia local no cordão espermático $(5 \mathrm{~mL}$ de cloridrato de lidocaína $2 \%$ sem 
vasoconstritor SC, Xylestesin $2 \%$ sem vasoconstritor, Cristália). Antes da injeção, foi feita uma inspeção do testículo receptor em busca de sinais de inflamação aguda devido à orquiectomia unilateral realizada $60 \mathrm{~h}$ antes. $\mathrm{O}$ escroto foi desinfetado com solução de álcool $92 \%(\mathrm{v} / \mathrm{v})$ e iodo $2 \%(\mathrm{v} / \mathrm{v})$. Após o preparo do animal para 0 transplante, foi realizada a injeção das células espermatogoniais, sendo a agulha introduzida lateralmente à cauda do epidídimo de forma a atingir longitudinalmente a região do mediastino. Para o acompanhamento da injeção, foi utilizada ultrassonografia com auxílio de uma probe linear de $5 \mathrm{MHz}$. Os testículos receptores foram observados por ultrassonografia antes e após o transplante (Figura 17).

Figura 17 -Imagens ultrassonográficas do acompanhamento do transplante autólogo de células espermatogoniais em bezerros pré-púberes. Imagens obtidas antes da injeção, demonstrando o parênquima testicular anecogênico (A, C, D). Imagens obtidas após injeção, demonstrando conteúdo líquido injetado hiperecogênico, indicado por setas vermelhas $(B, D, F)$

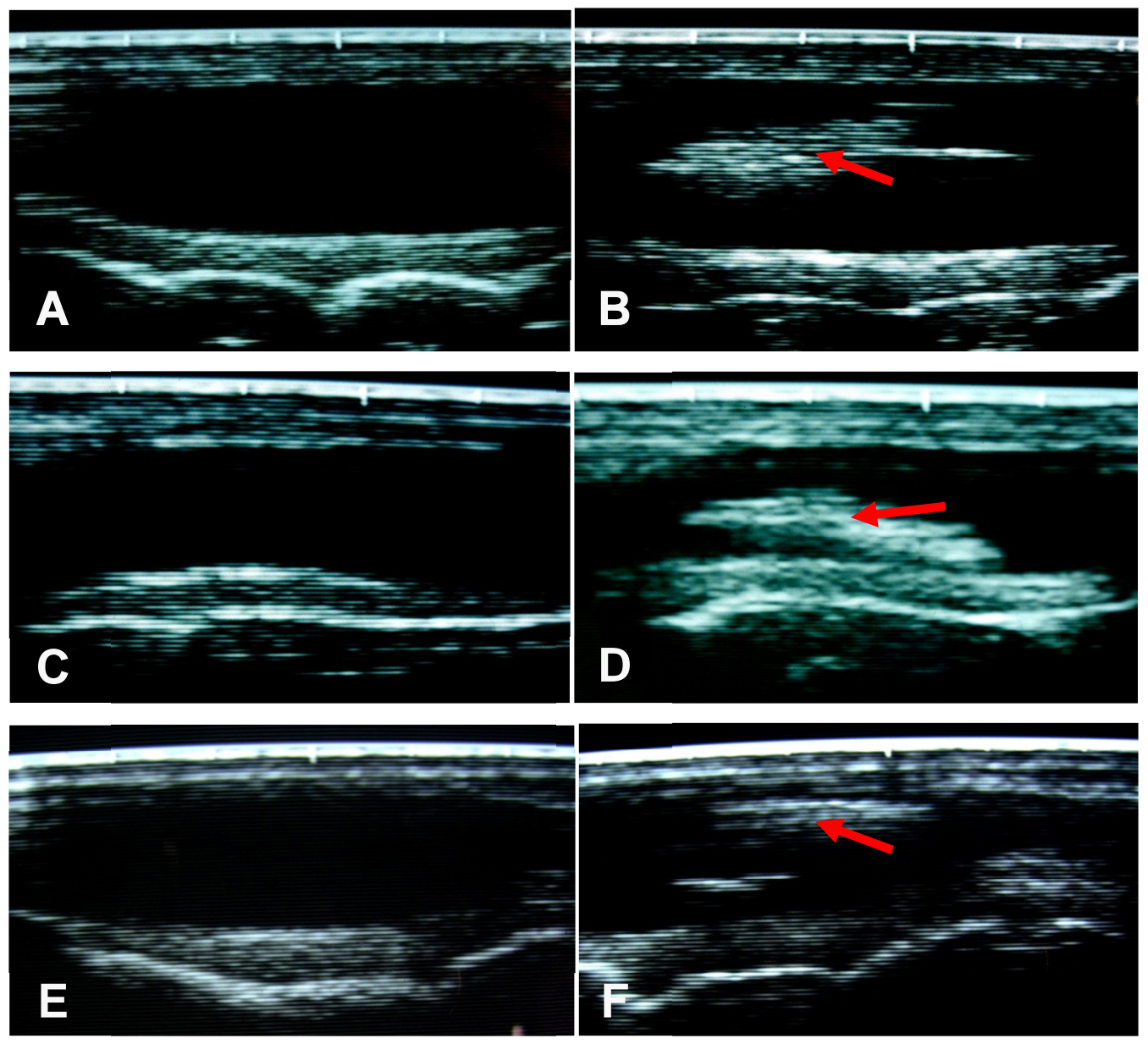




\subsubsection{Verificação da integração de células espermatogoniais LacZ+ e/ou marcadas com PKH26 aos túbulos seminíferos de bovinos pré-púberes da raça Nelore após transplante autólogo}

5.1.7.1 Orquiectomia do testículo receptor remanescente

Para a verificação da integração de células espermatogoniais bovinas LacZ+ aos túbulos seminíferos de bezerros pré-púberes da raça Nelore, os animais foram submetidos a uma segunda orquiectomia para remoção do testículo receptor remanescente.

A segunda orquiectomia foi realizada 45 dias após o transplante autólogo das células espermatogoniais isoladas do testículo doador. Após $12 \mathrm{~h}$ de jejum hídrico e alimentar, os animais foram sedados $(0,2 \mathrm{mg}$ de xilazina por quilograma de peso vivo IM, Anadesan, SESPO - Divisão Vetbrands Saúde Animal) e receberam anestesia local no cordão espermático ( $5 \mathrm{~mL}$ de cloridrato de lidocaína $2 \%$ sem vasoconstritor SC, Xylestesin 2\% sem vasoconstritor, Cristália). Antes da orquiectomia, todos os animais foram examinados para verificar sinais de inflamação ou formação de aderência no escroto em decorrência da primeira orquiectomia. Foi realizada uma incisão de $2 \mathrm{~cm}$ látero-caudal na bolsa escrotal com auxílio de lâmina de bisturi número 22. A túnica vaginal parietal foi incisada lateralmente para a total exposição do testículo. O cordão espermático foi fixado com pinça hemostática para realizar a ligadura com fio de sutura sintético absorvível Vicryl. O cordão espermático foi incisado distalmente à ligadura para excisão do testículo. Foi aplicada tintura de iodo $10 \%(\mathrm{v} / \mathrm{v})$ em etanol no local da ferida cirúrgica, seguida de antiparasitário em pó (Tanidil, Bayer). Os animais receberam pentabiótico [1 mL (187.500 e $62.500 \mathrm{UI}$ de Benzil penicilina Procaína e Potássica $+100 \mathrm{mg}$ de Estreptomicina base) para cada $25 \mathrm{~kg}$ de peso vivo IM SID, Agrosil 5 Mega, Vansil Saúde Animal] por 3 dias.

Os testículos foram imediatamente lavados em solução salina a $37^{\circ} \mathrm{C}$ e levados ao laboratório adjacente ao curral em saco plástico contendo salina. Os 
testículos foram novamente inspecionados quanto a presença de sinais de inflamação crônica ou aderências decorrentes do transplante.

Antes do início do processamento, os testículos foram lavados em salina a $37^{\circ} \mathrm{C}$ e borrifados com álcool $70 \%$ (v/v). Com auxílio de lâmina de bisturi número 22 , foi realizada uma incisão longitudinal da túnica vaginal visceral e túnica albugínea. O parênquima testicular foi totalmente dissecado da túnica albugínea (Figura 18, A). Após registro da massa, o testículo foi dividido com dois cortes transversais em três seções, cranial (SCr), central (SC) e caudal (SCa; Figura 18, B). A partir desta configuração, foram coletadas pelo menos 3 amostras de $125 \mathrm{~mm}^{3}$ de cada seção para cada uma das técnicas listadas e descritas no Quadro 4.

Figura 18 - Fotografias da coleta de amostras do testículo transplantado com células espermatogoniais. Em (A) testículo dissecado da túnica albugínea e em (B) testículo divido em três seções: cranial (SCr), central (SC) e caudal (SCa)

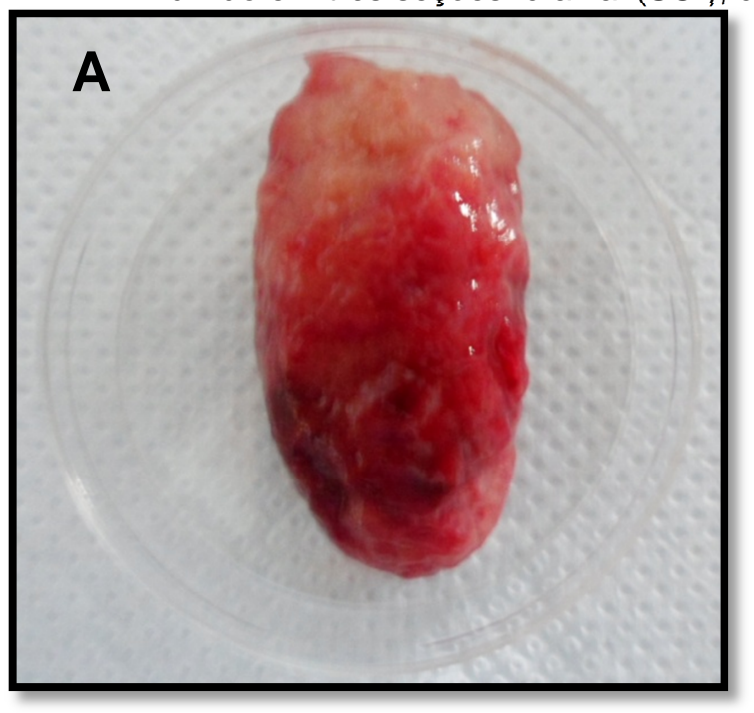

B

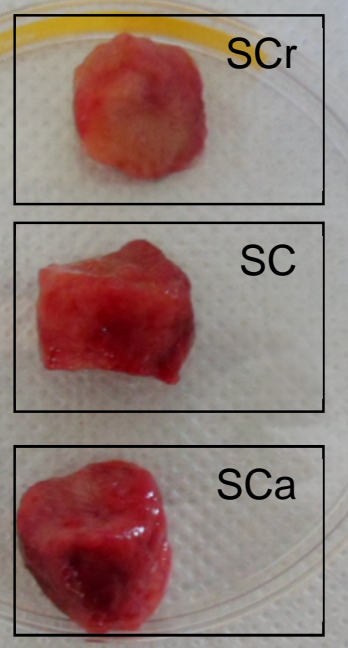


Quadro 4 - Lista de técnicas utilizadas para verificar integração de células espermatogoniais após transplante autólogo

\begin{tabular}{|c|c|}
\hline Técnica & Armazenamento do tecido \\
\hline $\begin{array}{l}\text { Detecção enzimática (x-gal) de } \\
\text { beta-galactosidase seguida de } \\
\text { parafinização }\end{array}$ & $\begin{array}{l}\text { Fixação em solução de paraformaldeído } 4 \% \text {, seguida de } \\
\text { reação com corante X-gal e armazenamento em formol } 10 \% \\
\text { (v/v) até a inclusão em parafina }\end{array}$ \\
\hline $\begin{array}{l}\text { Detecção enzimática (x-gal) de } \\
\text { beta-galactosidase seguida de } \\
\text { inclusão em resina para criostato }\end{array}$ & $\begin{array}{l}\text { Fixação em solução de glutaraldeído } 0,5 \% \text { (v/v), seguida de } \\
\text { reação com corante X-gal e armazenamento em } \\
\text { concentrações crescente de sacarose }[30,50 \text { e } 75 \%(\mathrm{~m} / \mathrm{v})] \text { até } \\
\text { a inclusão em resina para criostato }\end{array}$ \\
\hline $\begin{array}{l}\text { Identificação de células marcadas } \\
\text { com PKH26 (material parafinado) }\end{array}$ & $\begin{array}{l}\text { Fixação em solução de metacarne, seguida de } \\
\text { armazenamento em álcool } 95 \%(\mathrm{v} / \mathrm{v}) \text { até a inclusão em } \\
\text { parafina }\end{array}$ \\
\hline $\begin{array}{l}\text { Identificação de células marcadas } \\
\text { com PKH26 (material congelado) }\end{array}$ & $\begin{array}{l}\text { Fixação em solução de paraformaldeído } 4 \% \text { e glutaraldeído } \\
2 \%(\mathrm{v} / \mathrm{v}) \text {, seguida de armazenamento em concentrações } \\
\text { crescente de sacarose }[30,50 \text { e } 75 \%(\mathrm{~m} / \mathrm{v})] \text { até a inclusão em } \\
\text { resina para criostato }\end{array}$ \\
\hline
\end{tabular}

5.1.7.2 Detecção enzimática $(x-g a l)$ de beta-galactosidase

Um dos métodos para verificar a expressão da proteína beta-galactosidase é o ensaio enzimático com 0 corante X-gal (5-bromo-4-chloro-3-indolyl- $\beta$ galactopyranoside). A beta-galactosidase cliva o corante em galactose e um produto insolúvel azul. Assim, quando células positivas para expressão de betagalactosidase são submetidas à reação com X-gal, tornam-se azuis. Dessa forma, fragmentos de tecido do testículo receptor foram submetidos à reação com X-gal para a detecção de células espermatogoniais LacZ+.

Foram utilizados dois protocolos de detecção da expressão de betagalactosidase por reação enzimática com X-gal, um com processamento final do tecido em parafina e outro em resina para criostato (Tissue-Tek O.C.T Compound, Sakura, Holanda).

Para o processamento em parafina, 3 amostras de $125 \mathrm{~mm}^{3}$ de cada seção testicular descrita no item 5.1.8.2 foram coletadas com auxílio de pinça anatômica e 
tesoura cirúrgica de ponta reta e mantidas em solução fixadora contendo $4 \%(\mathrm{~m} / \mathrm{v})$ de paraformadeído e $0,1 \mathrm{M} \mathrm{NaH}_{2} \mathrm{PO}_{4}(\mathrm{pH}=7,3)$ a $4^{\circ} \mathrm{C}$ por $1 \mathrm{~h}$. Os fragmentos foram lavados três vezes em solução de lavagem contendo $0,1 \mathrm{M} \mathrm{NaH}_{2} \mathrm{PO}_{4}(\mathrm{pH}=7,3), 2$ $\mathrm{mM} \mathrm{MgCl} 2$ e $0,1 \%$ (v/v) de Triton-X 100 por 30 min cada lavagem. Para a coloração, os fragmentos foram incubados por $2 \mathrm{~h}$ a $37^{\circ} \mathrm{C}$ em solução contendo todos os componentes da solução de lavagem e $1 \mathrm{mg} / \mathrm{mL}$ de X-gal, $5 \mathrm{mM} \mathrm{K}{ }_{4} \mathrm{Fe}(\mathrm{CN})_{6}, \mathrm{pH}=7,3$ 7,6 . Foi realizada uma pós-fixação com solução de formalina $10 \%$ por $24-48 \mathrm{~h}$. $\mathrm{O}$ processamento das amostras desde a inclusão em parafina até a obtenção dos cortes histológicos foi realizado no Laboratório de Histologia do Departamento de Patologia Animal (VPT) da FMVZ-USP. Após inclusão em parafina e preparo dos blocos, foram cortadas em micrótomo seções de $5 \mu \mathrm{m}$ de espessura de cada amostra de tecido. As seções foram aderidas às lâminas de vidro silanizadas. Após 12-18 h em estufa a $80^{\circ} \mathrm{C}$, as lâminas foram submetidas a desparafinização e hidratação dos cortes. As lâminas foram incubadas 2 vezes em xilol por $15 \mathrm{~min}, 2$ vezes em etanol absoluto por $5 \mathrm{~min}, 1$ vez em etanol $95 \%$ (v/v) por $5 \mathrm{~min}$ e 1 vez em etanol $70 \%(\mathrm{v} / \mathrm{v})$ por $5 \mathrm{~min}$. Após desparafinização, as lâminas foram lavadas em água corrente por $5 \mathrm{~min}$ e incubadas com corante hematoxilina por $5 \mathrm{~min}$. As lâminas foram lavadas em água, banhadas em álcool-ácido rapidamente e lavadas em água corrente por $10 \mathrm{~min}$. $\mathrm{O}$ excesso de água foi retirado e as lâminas incubadas com eosina por $1 \mathrm{~min}$. Finalmente, as lâminas foram submetidas a diafanização (3 vezes em etanol 95\% (v/v) por 2 min, 2 vezes em etanol absoluto por 2 min, 1 vez em etanol-xilol por $1 \mathrm{~min}$ e 2 vezes em xilol por $3 \mathrm{~min}$ ). As lâminas foram montadas com lamínula e meio de montagem (Permount, Fisher Scientific, Nova Jersey, EUA). As lâminas foram avaliadas em microscopia óptica de luz (Olympus).

Para o processamento do tecido em resina para criostato, 3 amostras de 125 $\mathrm{mm}^{3}$ de cada seção testicular descrita no item 5.1.8.2 foram coletadas com auxílio de pinça anatômica e tesoura cirúrgica de ponta reta e mantidas em solução fixadora contendo $0,5 \%$ de glutaraldeído em PBS a $4^{\circ} \mathrm{C}$ por $12-18 \mathrm{~h}$, durante a noite. Os fragmentos foram enxaguados três vezes em PBS incubados em solução de 1 $\mathrm{mg} / \mathrm{mL}$ de X-gal, $5 \mathrm{mM} \mathrm{K}_{4} \mathrm{Fe}(\mathrm{CN})_{6}, 0,1 \mathrm{M} \mathrm{NaH}_{2} \mathrm{PO}_{4}(\mathrm{pH}=7,3), 2 \mathrm{mM} \mathrm{MgCl} 2$ e 0,1\% $(\mathrm{v} / \mathrm{v})$ de Triton-X 100 por $4 \mathrm{~h}$. Após lavagem em água destilada, os fragmentos foram incubados em soluções com concentrações crescentes de sacarose $(30 \%, 50 \mathrm{e}$ $75 \%$ ) a $4^{\circ} \mathrm{C}$ por 8-12 h em cada solução. Os fragmentos foram incluídos (Tissue-Tek O.C.T Compound, Sakura) e seções de $4 \mu \mathrm{m}$ de espessura cortadas em criostato. A 
inclusão do material em OCT, assim como a confeção das lâminas pelo corte do tecido em criostato foram realizadas no Laboratório de Genética da Profa. Irina Kerkis, no Instituto Butantan. Foram utilizadas lâminas silanizadas e contracoloração com hematoxilina de Harris (5 s). Após diafanização com lavagens em álcool 70\% (v/v), álcool 95\% (v/v), álcool absoluto (2x) e xilol (2x), as lâminas foram finalizadas com meio de montagem (Entellan, Merck) e lamínula. As lâminas foram avaliadas em microscopia óptica de luz (Olympus).

5.1.7.3 Verificação de células espermatogoniais marcadas com corante PKH26 nos testículos de bovinos pré-púberes após o transplante autólogo

Para a verificação da presença de células espermatogoniais transplantadas marcadas com corante de rastreamento celular PKH26 nos túbulos seminíferos dos testículos receptores, amostras foram fixadas e processadas para corte em micrótomo (amostras incluídas em parafina) ou criostato (amostras incluídas em resina para criostato).

Para as amostras incluídas em parafina, foram utilizados $10 \mathrm{~mL}$ da solução fixadora metacarne $[60 \%(\mathrm{v} / \mathrm{v})$ de metanol, 30\%(v/v) de clorofórmio e 10\%(v/v) de ácido acético glacial], (3 fragmentos por tubo de $15 \mathrm{~mL}$ ). Após $24 \mathrm{~h}$ de fixação em metacarne, os fragmentos foram transferidos para tubo cônico de centrífuga de 15 $\mathrm{mL}$ contendo $10 \mathrm{~mL}$ de etanol 95\% (v/v). A inclusão das amostras em parafina foi realizada no laboratório de histologia do VPT da FMVZ-USP, sendo os fragmentos acondicionados em cassetes de histologia. Após inclusão em parafina e preparo dos locos, foram cortadas em micrótomo seções de $5 \mu \mathrm{m}$ de espessura de cada amostra de tecido. As seções foram aderidas às lâminas de vidro silanizadas. Após 12-18 h em estufa a $80^{\circ} \mathrm{C}$, as lâminas foram submetidas à desparafinização e hidratação dos cortes. As lâminas foram incubadas 2 vezes em xilol por 15 min, 2 vezes em etanol absoluto por $5 \mathrm{~min}, 1$ vez em etanol 95\% (v/v) por 5 min e 1 vez em etanol $70 \%(v / v)$ por 5 min. Após desparafinização, as lâminas foram lavadas em água corrente por 5 min e incubadas com corante hematoxilina por $5 \mathrm{~min}$. As lâminas foram lavadas em água, banhadas em álcool-ácido rapidamente e lavadas em água corrente por 10 min. $O$ excesso de água foi retirado e as lâminas foram incubadas com eosina por 1 
min. Finalmente, as lâminas foram submetidas a diafanização (3 vezes em etanol 95\% ( $\mathrm{v} / \mathrm{v})$ por $2 \mathrm{~min}, 2$ vezes em etanol absoluto por $2 \mathrm{~min}, 1 \mathrm{vez}$ em etanol-xilol por 1 min e 2 vezes em xilol por $3 \mathrm{~min}$ ). As lâminas foram montadas com lamínula e meio de montagem (Permount, Fisher Scientific, Nova Jersey, EUA).

Para as amostras incluídas em resina para criostato, estas foram mantidas em solução fixadora contendo $0,5 \%$ de glutaraldeído em PBS a $4^{\circ} \mathrm{C}$ por $12-18 \mathrm{~h}$, durante a noite. Após lavagem em água destilada, os fragmentos foram incubados em soluções com concentrações crescentes de sacarose $(30 \%, 50$ e $75 \%)$ a $4^{\circ} \mathrm{C}$ por 8-12 h em cada solução. Os fragmentos foram incluídos (Tissue-Tek O.C.T Compound, Sakura) e seções de $4 \mu \mathrm{m}$ de espessura cortadas em criostato. Foram utilizadas lâminas silanizadas e contra-coloração com hematoxilina de Harris (5 s). Após diafanização com lavagens em álcool $70 \%(\mathrm{v} / \mathrm{v})$, álcool $95 \%(\mathrm{v} / \mathrm{v})$, álcool absoluto $(2 \mathrm{x})$ e xilol $(2 \mathrm{x})$, as lâminas foram finalizadas com meio de montagem (Entellan, Merck) e lamínula.

As lâminas de ambas técnicas foram avaliadas em microscopia de epifluorescência (Olympus) com filtro para rodamina (comprimentos de onda para excitação e emissão de 550 e 573 nm, respectivamente).

\subsubsection{Caracterização celular}

5.1.8.1 Deteção da expressão de PGP9.5 e alfa-6 integrina por reação de imunofluorescência e afinidade pela lectina DBA de células espermatogoniais isoladas de bovinos pré-púberes

Após o plaqueamento diferencial (D1), amostras de $1 \times 10^{6}$ células viáveis foram fixadas em etanol $70 \%(\mathrm{v} / \mathrm{v})$ gelado $\left(4^{\circ} \mathrm{C}\right)$ e armazenadas a $-20^{\circ} \mathrm{C}$. As amostras fixadas foram lavadas 3 vezes em PBS $(400 \times \mathrm{g} / 5 \mathrm{~min}$ cada) para remoção do etanol. Para bloqueio de sítios inespecíficos, as células foram incubadas com solução de $5 \%(\mathrm{~m} / \mathrm{v})$ de BSA em PBS por $30 \mathrm{~min}$, novamente lavadas como descrito anteriormente e incubadas com anticorpo primário (1:100) anti-PGP9.5 (mouse monoclonal to PGP9.5, ab72911, Abcam, Cambridge, MA, EUA) em PBS 
contendo $1 \%(\mathrm{~m} / \mathrm{v})$ de $\mathrm{BSA}$ a $4^{\circ} \mathrm{C}$ por $12-18 \mathrm{~h}$. Após 3 lavagens em PBS (400 $\mathrm{x} \mathrm{g/} 5 \mathrm{~min}$ cada), as células foram incubadas com anticorpo secundário (1:200; goat polyclonal secondary antibody to mouse IgG - H\&L FITC, Abcam) por $1 \mathrm{~h} \mathrm{a}$ temperatura ambiente no escuro. Após 3 lavagens em PBS, foi realizada uma última incubação por $10 \mathrm{~min}$ com solução de $5 \mu \mathrm{g} / \mathrm{mL}$ de Hoechst 33342 em PBS. As amostras foram novamente lavadas em PBS e ressuspendidas em $100 \mu \mathrm{L}$ de PBS, sendo $10 \mu \mathrm{L}$ colocados entre lâmina e lamínula. O mesmo procedimento foi utilizado para verificar a expressão do marcador alfa-6 integrina [Rat monoclonal (GoH3) Integrin alpha 6 associado ao FITC, Abcam, Cambridge, MA, EUA], diluição 1:20. Por último, para a marcação com DBA, foi utilizada a lectina DBA conjugada ao fluoróforo FITC (Sigma). As células fixadas foram lavadas 3 vezes em PBS (400 x g/5 min cada) para remoção do etanol. Para bloqueio de sítios inespecíficos, as células foram incubadas com solução de $5 \%(\mathrm{~m} / \mathrm{v})$ de BSA em PBS por $30 \mathrm{~min}$. As células foram lavadas 3 vezes em PBS $(400 \times \mathrm{g} / 5 \mathrm{~min}$ cada) e incubadas com $2,5 \mu \mathrm{g} / \mathrm{mL}$ de DBA em PBS a $4^{\circ} \mathrm{C}$ por $12-18 \mathrm{~h}$. Em seguida, as células foram lavadas 3 vezes em PBS e incubadas com solução de $5 \mu \mathrm{g} / \mathrm{mL}$ de Hoechst 33342 em PBS por $10 \mathrm{~min}$. Após lavagens com PBS (3 vezes), as células foram ressuspendidas em $100 \mu \mathrm{L}$ de PBS, sendo $10 \mu \mathrm{L}$ colocados entre lâmina e lamínula. As lâminas foram avaliadas em microscópio de epifluorescência (Olympus) com filtro verde para FITC (comprimentos de onda para excitação e emissão de 488 e 520 nm, respectivamente) e azul para marcação do núcleo celular (Hoechst 33342; comprimentos de onda para excitação e emissão de 345 e 483 nm, respectivamente).

5.1.8.2 Expressão gênica dos marcadores ITGA6, GFRa-1 e PGP9.6 em células espermatogoniais isoladas de bovinos pré-púberes

A verificação da expressão dos marcadores alfa-6 integrina (ITGA6), GFRa-1 e PGP9.5 foi realizada por reação de RT-PCR em tempo real. Assim, o RNA total de amostras de células espermatogoniais ( $1 \times 10^{6}$ células/ amostra) obtidas após 12-18 $\mathrm{h}$ de cultivo in vitro (D1) foi extraído com llustra RNAspin Mini RNA Isolation Kit (GE Healthcare, Buckinghamshire, Reino Unido), seguindo as instruções do fabricante. $O$ 
RNA total foi eluído da coluna com volume de $40 \mu \mathrm{L}$ de água tratada com dietilpirocarbonato (DEPC). A concentração de RNA total foi verificada por espectrofotometria (Nanodrop ND-1000, Nanodrop Technologies, Inc.,Wilmington, Delaware, EUA) para normalizar as reações de síntese de cDNA, sendo utilizados $100 \mathrm{ng}$ de RNA total em cada reação. Após a extração, o cDNA foi sintetizado com Superscript $\Theta$ VILO ${ }^{T M}$ CDNA synthesis kit (Invitrogen).

As análises de RT-PCR em tempo real foram realizadas no sistema de detecção LineGene 9600 (Bioer Technology, Hangzhou, China), utilizando o SYBR GreenER ${ }^{T M}$ qPCR Supermix Universal (Invitrogen) com $10 \mu \mathrm{L}$ de volume por reação. Como controles endógenos foram utilizados os genes gliceraldeído 3-fosfato desidrogenase (GAPDH) e beta actina (ACTB). Para todas as amplificações, foi utilizado um programa de 3 passos: $95^{\circ} \mathrm{C} / 15 \mathrm{~s}, 55^{\circ} \mathrm{C} / 15 \mathrm{~s}$ e $68^{\circ} \mathrm{C} / 20 \mathrm{~s}$ por 45 ciclos, seguido da curva de dissociação. Como controle negativo da reação utilizouse a mesma reação sem a adição da amostra de cDNA.

As razões de expressão dos genes alvo (ITGA6, GFRa-1 e PGP9.5) foram normalizadas pela razão da expressão dos controles endógenos (ACTB e GAPDH).

5.1.8.3 Detecção da expressão de PGP9.5 por imuno-histoquímica e afinidade por DBA em amostras de tecido dos testículos doadores de células espermatogoniais de bovinos pré-púberes

Após fixação de amostras de tecido dos testículos doadores de células espermatogoniais de bezerros pré-púberes em metacarne por $24 \mathrm{~h}$, as amostras foram transferidas para tubo cônico de centrífuga de $15 \mathrm{~mL}$ contendo $10 \mathrm{~mL}$ de etanol $95 \%(\mathrm{v} / \mathrm{v})$, onde permaneceram até início do processo de parafinização. $O$ processamento das amostras desde a inclusão em parafina até a obtenção dos cortes histológicos foi realizado no Laboratório de Histologia do VPT da FMVZ-USP. Após inclusão em parafina e preparo dos locos, foram cortadas em micrótomo seções de $5 \mu \mathrm{m}$ de espessura de cada amostra de tecido. As seções foram aderidas às lâminas de vidro silanizadas para realizar reações de imuno-histoquímica (detecção de PGP9.5) e reação com lectina conjugada (afinidade ao DBA), as quais 
foram realizadas no Laboratório do Prof. Dr. Paulo C. Maiorka, no VPT da FMVZUSP.

As lâminas foram submetidas à desparafinização e hidratação dos cortes. As lâminas foram incubadas 2 vezes em xilol por $15 \mathrm{~min}, 2$ vezes em etanol absoluto por $5 \mathrm{~min}, 1 \mathrm{vez}$ em etanol 95\% (v/v) por $5 \mathrm{~min}$ e 1 vez em etanol $70 \%(\mathrm{v} / \mathrm{v})$ por 5 min. Após desparafinização, as lâminas foram lavadas em água corrente por 5 min e a recuperação antigênica foi feita com solução de citrato de sódio $10 \mathrm{mM}$ em microondas por 5 min (potência alta). Após resfriar em temperatura ambiente, as lâminas foram lavadas em água corrente por $5 \mathrm{~min}$ e o bloqueio da peroxidase foi realizado por incubação em solução de $5 \%(\mathrm{v} / \mathrm{v})$ de peróxido de hidrogênio em água destilada a $37^{\circ} \mathrm{C}$ por $15 \mathrm{~min}$. Após lavagem em água corrente por $5 \mathrm{~min}$, foi realizado o bloqueio dos sítios inespecíficos com solução de $5 \%(\mathrm{~m} / \mathrm{v})$ de leite desnatado e $1 \%$ $(\mathrm{m} / \mathrm{v})$ de BSA em PBS a $37^{\circ} \mathrm{C}$ por $20 \mathrm{~min}$. As incubações com anticorpo primário (mouse monoclonal to PGP9.5, ab72911, Abcam, Cambridge, MA, EUA), diluição 1:100 em solução de $5 \%(\mathrm{~m} / \mathrm{v})$ de leite desnatado e $1 \%(\mathrm{~m} / \mathrm{v})$ de BSA em PBS ou com DBA (DBA conjugado ao fluoróforo FITC, Sigma), $2 \mu \mathrm{M}$ em solução de $5 \%(\mathrm{~m} / \mathrm{v})$ de leite desnatado e $1 \%(\mathrm{~m} / \mathrm{v})$ de BSA foram feitas durante a noite, por 12-18 h, em câmara úmida, a $37^{\circ} \mathrm{C}$. Para diminuir a quantidade de anticorpo foi fixado um volume de $200 \mu \mathrm{L}$, tanto para a diluição do anticorpo primário anti-PGP9.5 quanto para o DBA. Para conter este volume sobre o corte foi desenhado um círculo ao redor do corte com caneta hidrofóbica (Dako) e os $200 \mu \mathrm{L}$ depositados sobre o corte, de forma a cobri-lo integralmente. Após $12-18 \mathrm{~h}$, as lâminas foram lavadas 3 vezes em PBS por 5 min cada lavagem.

As lâminas incubadas com anticorpo primário anti-PGP9.5 foram incubadas com $100 \mu \mathrm{L}$ da solução de link (anticorpo secundário anti-mouse em tampão tris$\mathrm{HCl}$, Advance TM HRP Link, Dako, Califórnia, EUA) por $30 \mathrm{~min}$ a $37^{\circ} \mathrm{C}$. Após 3 lavagens de 5 min em PBS, as lâminas foram incubadas com $100 \mu \mathrm{L}$ da enzima peroxidase de rábano (HRP, do inglês horseradish peroxidase, em tampão tris- $\mathrm{HCl}$, Advance $^{\mathrm{TM}}$ HRP Enzyme, Dako) por $30 \mathrm{~min}$ a $37^{\circ} \mathrm{C}$. Após 3 lavagens de $5 \mathrm{~min}$ em PBS, as lâminas foram finalmente incubadas com $100 \mu \mathrm{L}$ da solução de cromógeno $(20 \mu \mathrm{L}$ de cromógeno DAB para cada $1 \mathrm{~mL}$ da solução tampão Imidazole-HCl buffer; kit Liquid DAB+ Substrate Chromogen System, Dako) por $1 \mathrm{~min}$, sendo a reação bloqueada com lavagem em água corrente (5 min). Foi realizada a contra-coloração com hematoxilina de Harris (30 s) para visualização dos núcleos celulares. As 
lâminas foram lavadas em água corrente por $5 \mathrm{~min}$. As lâminas foram submetidas à diafanização (1 vez em etanol 70\% (v/v) por $5 \mathrm{~min}, 1 \mathrm{vez}$ em etanol 95\% (v/v) por 5 min, 2 vezes em etanol absoluto por 5 min e 2 vezes em xilol por $15 \mathrm{~min}$ ) e montagem com lamínula e meio de montagem (Entellan, Merck, Darmstadt, Alemanha). O controle negativo da reação foi realizado para todas as amostras, não sendo realizada somente a incubação com o anticorpo primário. As lâminas foram avaliadas em microscopia óptica de luz (Olympus), sendo obtidas imagens pelo programa ImagePlus. Com o auxílio do programa ImageJ (National Institute of Mental Health, NIH, EUA) foram contadas manualmente as células positivas para marcação com anticorpo anti-PGP9.5 por túbulo seminífero, sendo avaliados 100 túbulos seminíferos por amostra.

As lâminas incubadas com a lectina DBA foram incubadas com solução de $5 \mu \mathrm{g} / \mathrm{mL}$ de Hoechst 33342 em PBS por 15 min para marcação dos núcleos celulares. Após lavagem em PBS por $5 \mathrm{~min}$, as lâminas foram montadas com o antifade contendo DAPI (Vectashield, Vector Laboratories, Califórnia, EUA) e lamínula. O controle negativo da reação foi realizado para todas as amostras, não sendo realizada a incubação com a lectina. As lâminas foram avaliadas em microscópio de epifluorescência (Olympus) com filtro verde para FITC (comprimentos de onda para excitação e emissão de 488 e 520 nm, respectivamente) e azul para a marcação do núcleo celular (Hoechst 33342; comprimentos de onda para excitação e emissão de 345 e 483 nm, respectivamente).

\subsubsection{Análise Estatística}

Foi realizada a análise de variância dos quadrados mínimos, utilizando o recurso GLM (do inglês general linear model) ANOVA do programa Minitab (Minitab ${ }^{\circledR}$ 16.1.0, Minitab Inc.). Os dados foram testados quanto à normalidade dos resíduos (teste Anderson-Darling) e homogeneidade das variâncias (teste de Bartlett e teste de Levene). Quando não foram atendidas as premissas para análise de variância, os dados foram estudados como não-paramétricos, pelo teste de Kruskall- 
Wallis. Todos os dados foram apresentados como média dos quadrados mínimos (LSM, do inglês least square means) \pm erro padrão da média (SEM). Foi considerado o intervalo de confiança de $95 \%$.

Na primeira fase deste trabalho, foi estudado o efeito da divisão dos animais em lotes (variável independente) para realizar a orquiectomia unilateral (retirada do testículo doador de células espermatogoniais) sobre a quantidade de células isoladas por grama de tecido e viabilidade celular no dia do isolamento (variáveis dependentes).

\subsection{RESULTADOS}

\subsubsection{Isolamento de células espermatogoniais de bovinos pré-púberes}

\subsubsection{Digestão enzimática}

Para 0 isolamento das células espermatogoniais 16 bezerros pré-púberes foram submetidos à orquiectomia unilateral. Foi observada uma massa média de tecido testicular de 6,849 \pm 0,472 g após a dissecção da túnica albugínea.

A digestão enzimática permitiu 0 isolamento de aproximadamente $5,79 \times 10^{7} \pm 8,36 \times 10^{6}$ células $/ g$ de tecido. Não foi observada diferença na quantidade de células por grama de tecido testicular quando foram comparados os quatro lotes de animais, correspondentes a quatro dias de orquiectomia unilateral consecutivos $(p=0,164)$.

Utilizando o método de exclusão com azul de tripan, foi observada uma viabilidade média de $84,49 \pm 3,02 \%$, sendo encontrados os valores mínimo e máximo de 58,62 e $96,44 \%$, respectivamente. Assim como o observado para quantidade de células isoladas, não foi detectado efeito de lote na viabilidade das células, avaliada no dia do isolamento enzimático ( $D 0 ; p=0,188$ ). 


\subsubsection{Plaqueamento Diferencial}

Após o plaqueamento diferencial, verificou-se viabilidade média de 77,75 \pm $3,21 \%$, sendo encontrados valores mínimo e máximo de 52,54 e 97,06\%, respectivamente. Quando comparada à viabilidade das células após 12-18 h de cultivo in vitro (D1) observou efeito de lote ( $p=0,025$; Tabela 3 ).

Ao observar a morfologia à microscopia óptica de luz, foi possível verificar cultura celular bastante homogênea, sendo observadas células de tamanho e morfologia bastante semelhantes (Figura 19).

Tabela 3 - Médias das porcentagens de células viáveis (LSM + SEM) de células espermatogoniais dos 4 lotes de bezerros pré-púberes da raça Nelore após 12-16 h de cultivo in vitro (D1) - São Paulo - 2012

\begin{tabular}{cc}
\hline Lote & Viabilidade $(\%)$ \\
\hline 1 & $89,71 \pm 4,871^{\mathrm{a}}$ \\
2 & $84,32 \pm 4,871^{\mathrm{a}, \mathrm{b}}$ \\
3 & $69,30 \pm 4,871^{\mathrm{a}, \mathrm{b}}$ \\
4 & $67,67 \pm 4,871^{\mathrm{b}}$ \\
\hline
\end{tabular}

Médias com letras sobrescritas diferentes na mesma coluna são diferentes $(p<0,05)$. 
Figura 19 - Fotografia de microscopia óptica de luz de células espermatogoniais de bezerros prépúberes cultivadas in vitro. Imagem após o plaqueamento diferencial (D1) (Magnificação de $400 \mathrm{x})$

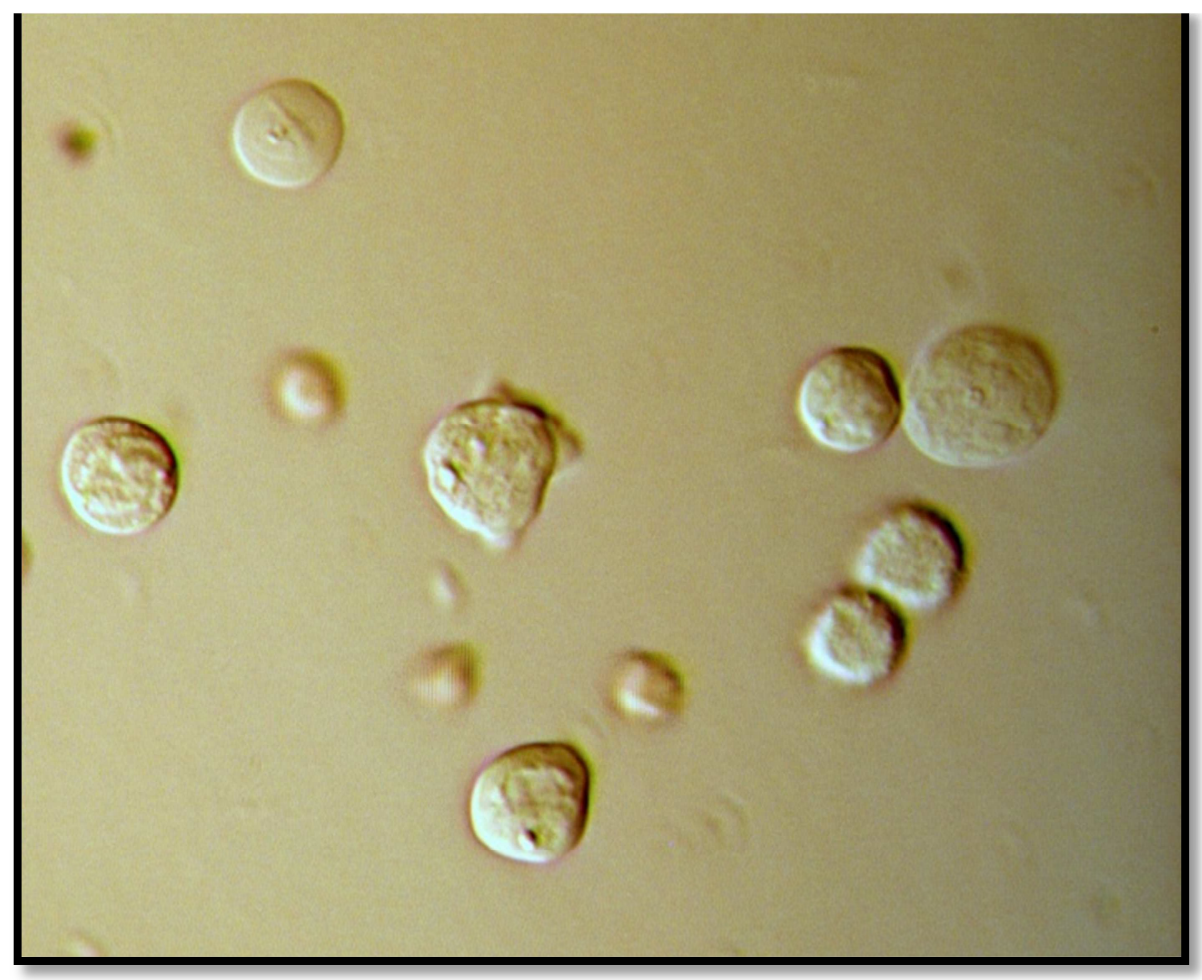

5.2.2 Verificação da integração de células espermatogoniais LacZ+ e/ou marcadas com PKH26 aos túbulos seminíferos de bovinos pré-púberes da raça Nelore após transplante autólogo

5.2.2.1 Orquiectomia do testículo receptor

O exame dos testículos receptores realizados antes e depois da orquiectomia não revelaram nenhuma alteração da gônada e nenhum sinal de inflação ou aderência decorrente da remoção do testículo contralateral e ou da injeção intratesticular de células espermatogoniais. 
Foi observada massa média de tecido testicular de 15,585 $\pm 1,09 \mathrm{~g}$ após a dissecção da túnica albugínea do testículo receptor 45 dias depois do transplante autólogo. Não foi detectada diferença na massa dos testículos dos diferentes grupos experimentais $(p=0,646$; Tabela 4$)$.

Tabela 4 - Médias das massas (LSM \pm SEM) de tecido dissecado dos testículos receptores 45 dias após transplante autólogo com células espermatogoniais de bezerros pré-púberes da raça Nelore - São Paulo - 2012

\begin{tabular}{cc}
\hline Grupo & Massa $(\mathrm{g})$ \\
\hline 1 & $15,03 \pm 2,28^{\mathrm{a}}$ \\
2 & $16,01 \pm 2,28^{\mathrm{a}}$ \\
3 & $17,70 \pm 2,28^{\mathrm{a}}$ \\
4 & $13,60 \pm 2,28^{\mathrm{a}}$ \\
\hline
\end{tabular}

5.2.2.2 Detecção enzimática (x-gal) de beta-galactosidase

Para verificação da integração de células espermatogoniais LacZ+ nos túbulos seminíferos de bezerros pré-púberes da raça Nelore após transplante autólogo, foram utilizados dois protocolos de detecção da expressão de betagalactosidase por reação enzimática com X-gal, um com processamento final do tecido em parafina e outro em resina para criostato, OCT.

Somente o protocolo com fixação das células com glutaraldeído, incubadas com corante $x$-gal e finalmente incluídas em OCT permitiu a visualização de células espermatogoniais LacZ+ nos testículos transplantados (Figura 20). De 8 animais que receberam células espermatogoniais transgênicas ( $\mathrm{LacZ}_{+}$; Grupos 1 e 2), foi possível observar em todos a presença de células expressando a proteína betagalactosidase. Não foram observadas células azuis nos animais nas amostras dos animais pertencentes aos Grupos 3 e 4 (LacZ-).

Todas as células LacZ+ observadas nas amostras dos animais positivos estavam localizadas fora dos túbulos seminíferos, como pode ser observado na 
Figura 20. Não foi observada integração das células transgênicas aos túbulos seminíferos em nenhuma das amostras avaliadas histologicamente.

Figura 20 - Fotografias de crioseções de amostras de testículos transplantados com células espermatogoniais LacZ+, removidos cirurgicamente após 45 dias do transplante autólogo. $O$ tecido foi submetido à reação enzimática com o corante x-gal para visualização das células transgênicas, em azul (setas vermelhas). Microscopia de luz (Magnificação de 400x)
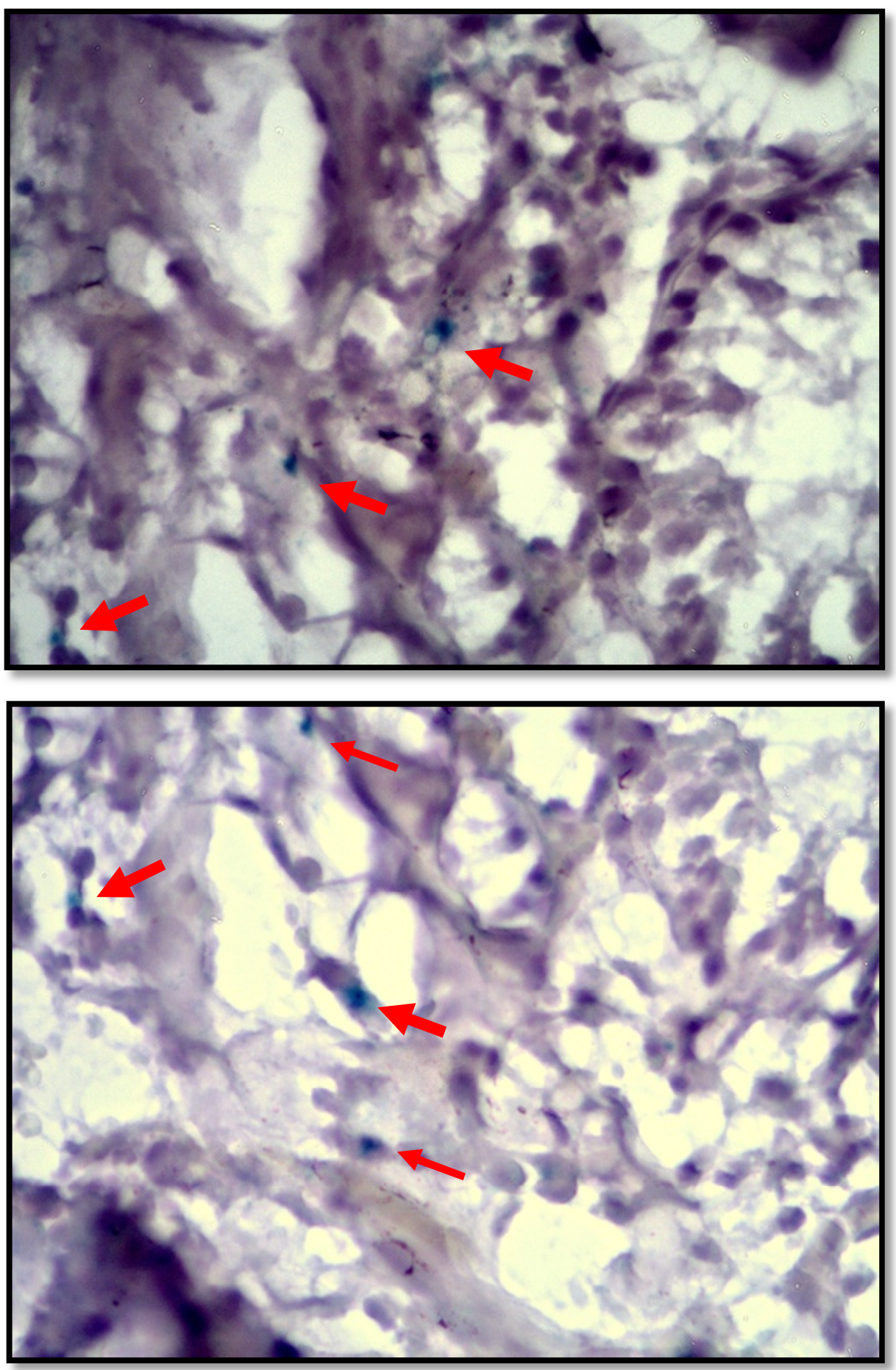
Figura 20 - (Continuação) Fotografias de crioseções de amostras de testículos transplantados com células espermatogoniais LacZ+, removidos cirurgicamente após 45 dias do transplante autólogo. O tecido foi submetido à reação enzimática com o corante x-gal para visualização das células transgênicas, em azul (setas vermelhas). Microscopia de luz (Magnificação de 400x)
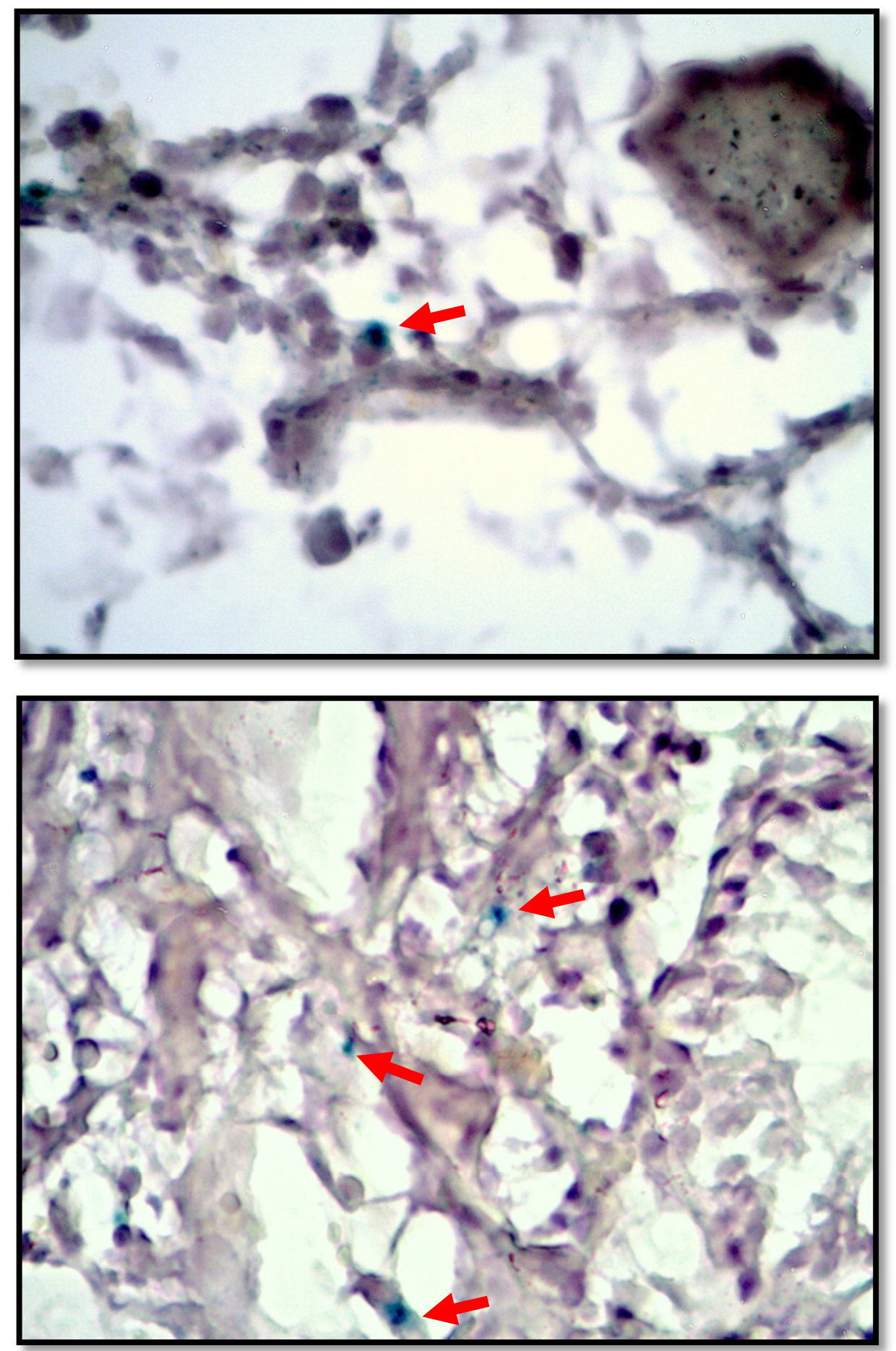
5.2.2.3 Verificação da presença de células espermatogoniais marcados com o corante PKH26 nos testículos de bovinos pré-púberes após o transplante autólogo

Não foi possível observar a integração de células espermatogoniais marcadas com o corante de rastreamento celular $\mathrm{PKH} 26$ nos túbulos seminíferos dos testículos receptores após o transplante autólogo. Tanto as lâminas processadas em parafina quanto os cortes feitos em criostato não permitiram a visualização das células coradas, pois o tecido apresentou forte autofluorescência vermelha.

\subsubsection{Caracterização celular}

5.2.3.1 Deteção da expressão de PGP9.5 e alfa-6 integrina por reação de imunofluorescência e afinidade pela lectina DBA de células espermatogoniais isoladas de bovinos pré-púberes

Foi observada a expressão dos marcadores de SSCs PGP9.5, DBA e ITGA6 pelas células espermatogoniais isoladas de bezerros pré-púberes da raça Nelore (Figuras 21, 22 e 23). 
Figura 21 - Fotografias de microscopia de epifluorescência de células espermatogoniais isoladas de bezerros pré-púberes da raça Nelore submetidas à detecção da expressão do marcador PGP9.5 por reação de imunofluorescência. Núcleos celulares marcados com Hoechst (azul) (A), células marcadas com anticorpo anti-PGP9.5 e anticorpo secundário conjugado ao fluoróforo FITC (verde) (B) e sobreposição das imagens A e B (C) (Magnificação de 400 x)
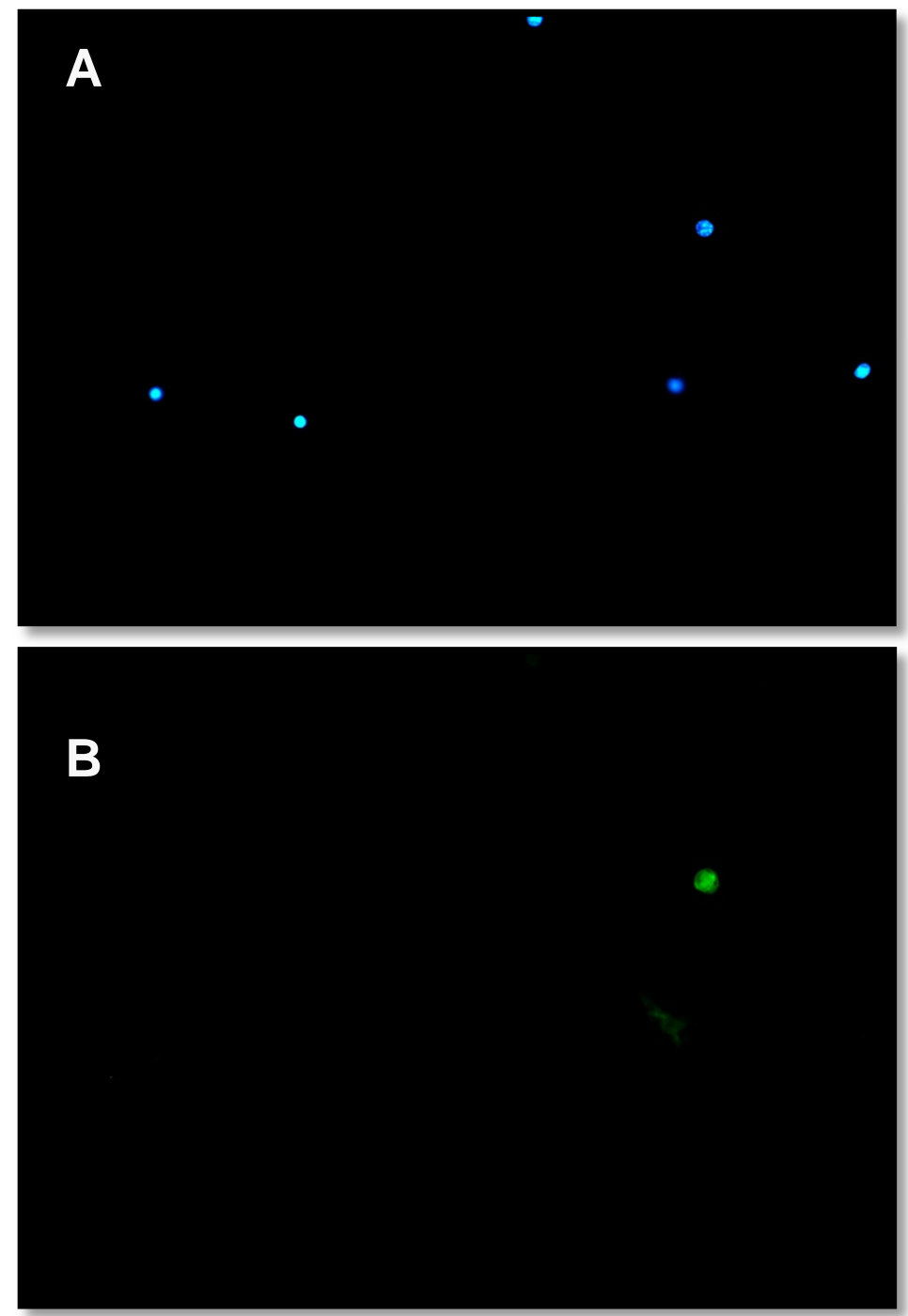
Figura 22 - Fotografias de microscopia de epifluorescência de células espermatogoniais isoladas de bezerros pré-púberes da raça Nelore com afinidade por DBA. Núcleos celulares marcados com Hoechst (azul) (A), células marcadas com anticorpo anti-PGP9.5 e anticorpo secundário conjugado ao fluoróforo FITC (verde) (B) e sobreposição das imagens A e B (C) (Magnificação de 400 x)
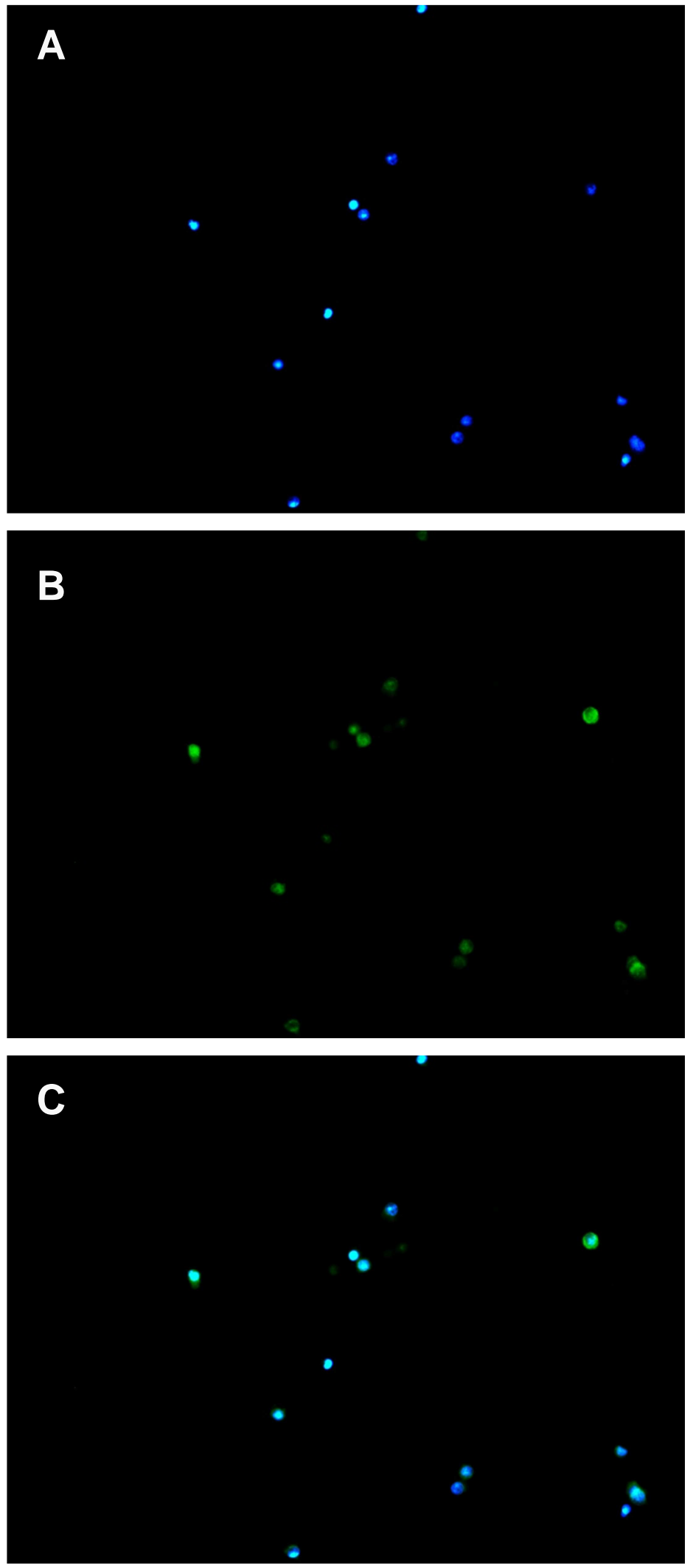
Figura 23 - Fotografias de microscopia de epifluorescência de células espermatogoniais isoladas de bezerros pré-púberes da raça Nelore submetidas à detecção da expressão do marcador PGP9.5 por reação de imunofluorescência. Núcleos celulares marcados com Hoechst (azul) $(A)$, células marcadas com anticorpo anti-alfa-6 integrina conjugado ao fluoróforo FITC (verde) (B) e sobreposição das imagens A e B (C) (Magnificação de 400 x)
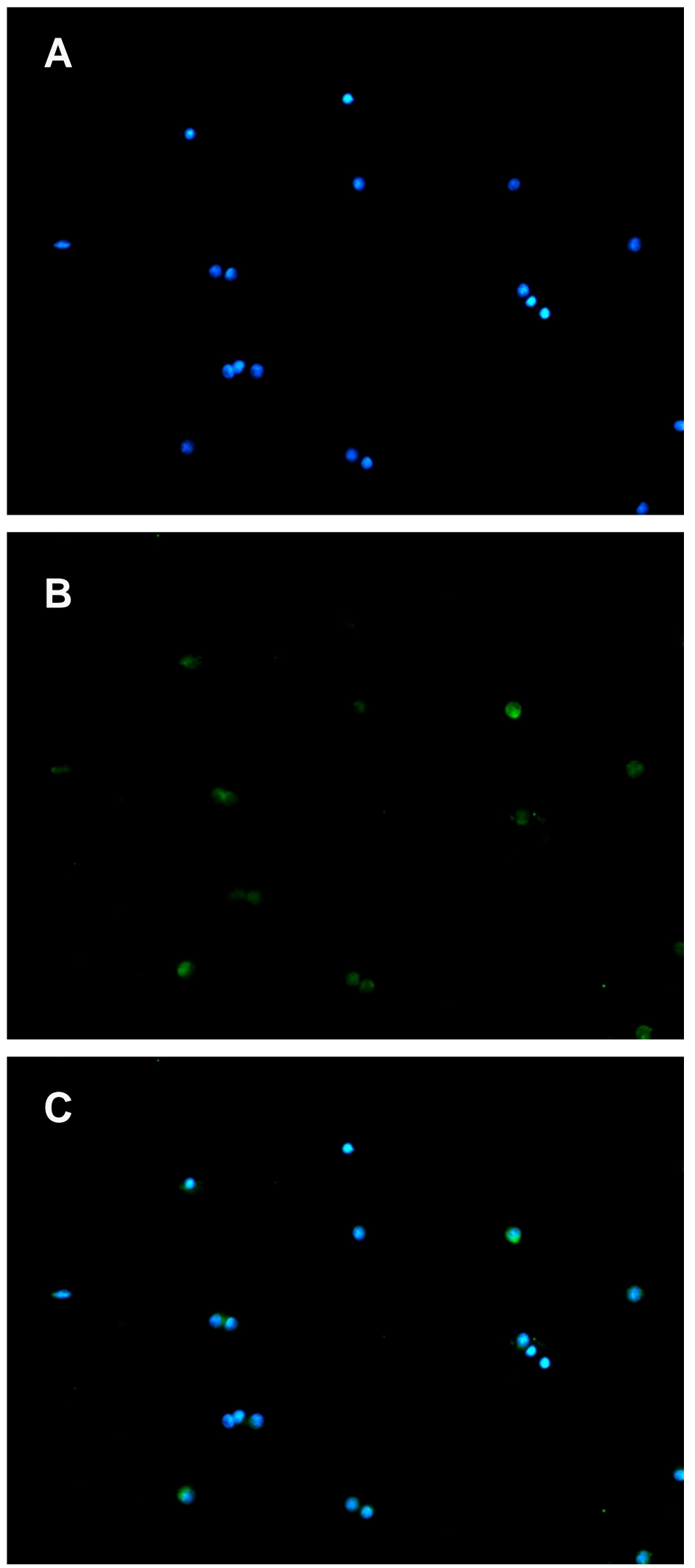
5.2.3.2 Expressão gênica dos marcadores ITGA6, GFRa-1 e PGP9.6 em células espermatogoniais isoladas de bovinos pré-púberes

Foi realizada a avaliação da expressão gênica por RT-PCR em tempo real dos marcadores ITGA6, GFRa-1 e PGP9.5 em células espermatogoniais bovinas isoladas de bezerros pré-púberes. Foi detectada a expressão de todos os genes estudados em todas as amostras avaliadas (Figura 24).

Figura 24 - Expressão relativa dos genes ITGA6, GFR-1 e PGP9.5 em células espermatogoniais de bovinos adultos avaliado por reação de RT-PCR em tempo real

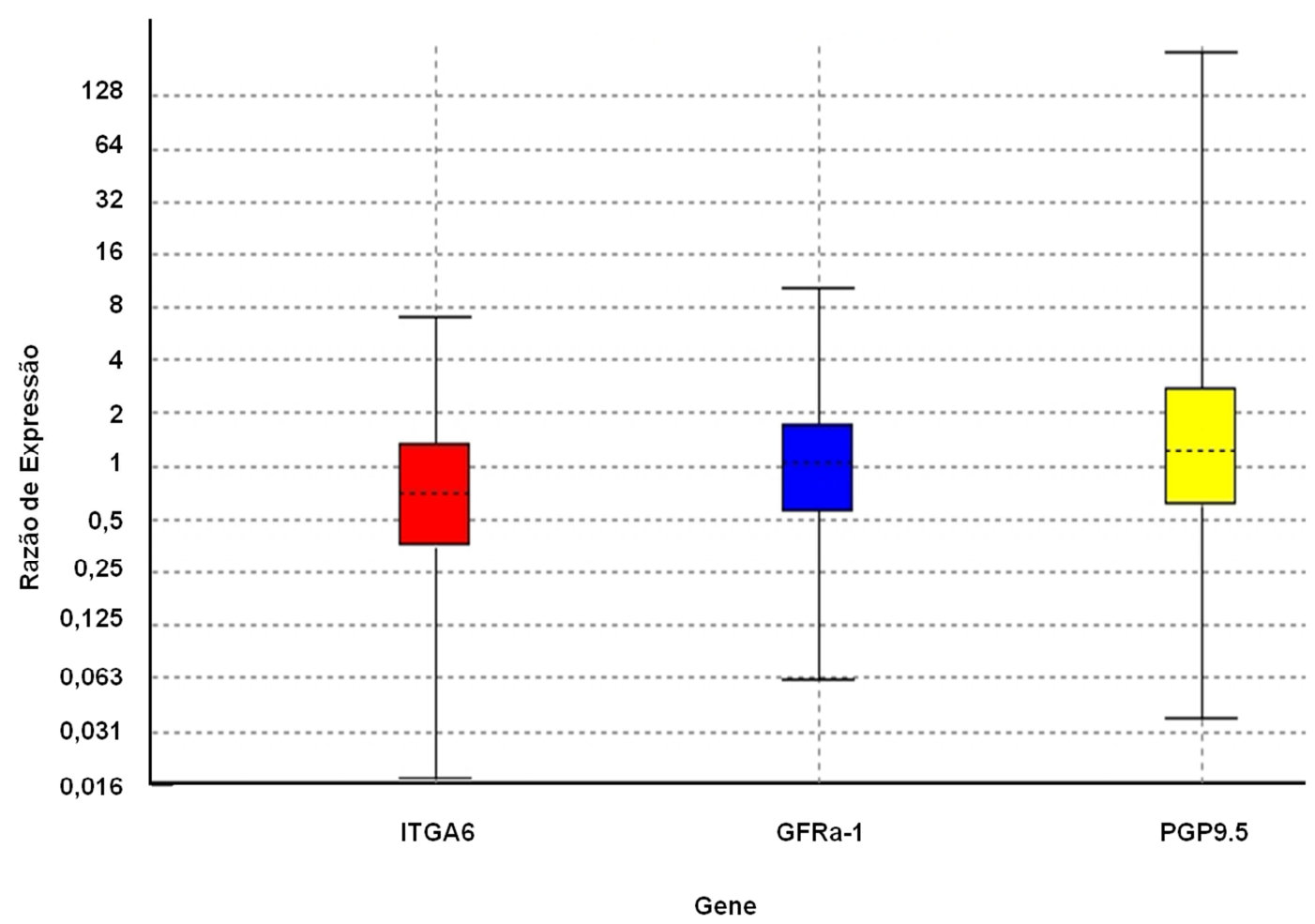


5.2.3.3 Detecção da expressão de PGP9.5 por imuno-histoquímica e afinidade por DBA em amostras de tecido dos testículos doadores de células espermatogoniais de bovinos pré-púberes

A reação de imuno-histoquímica em amostras do testículo doador de células espermatogoniais para verificação da expressão de PGP9.5, marcador de SSCs, foi positiva em todas as amostras. Foi observada média de $82 \pm 8,35 \%$ de túbulos seminíferos positivos para marcação com PGP9.5, sendo encontradas em média $2,56 \pm 0,237$ células positivas por túbulo seminífero positivo.

A Figura 25 ilustra uma lâmina de imuno-histoquímica para verificar a expressão de PGP9.5 em amostras dos testículos doadores.

Pela reação com lectina conjugada para detecção da afinidade das células espermatogoniais por DBA, verificou-se a presença de células próximas à membrana basal dos túbulos seminíferos com afinidade à lectina DBA (Figura 26). 
Figura 25 - Fotografia de corte histológico submetido à reação de imuno-histoquímica para verificar a expressão do marcador de SSCs, PGP9.5, em amostras de testículos doadores de células espermatogoniais. Células marcadas em marrom representam células positivas para expressão de PGP9.5. Contra-coloração em azul realizada com hematoxilina de Harris para marcação dos núcleos celulares (Magnificação de 400x)

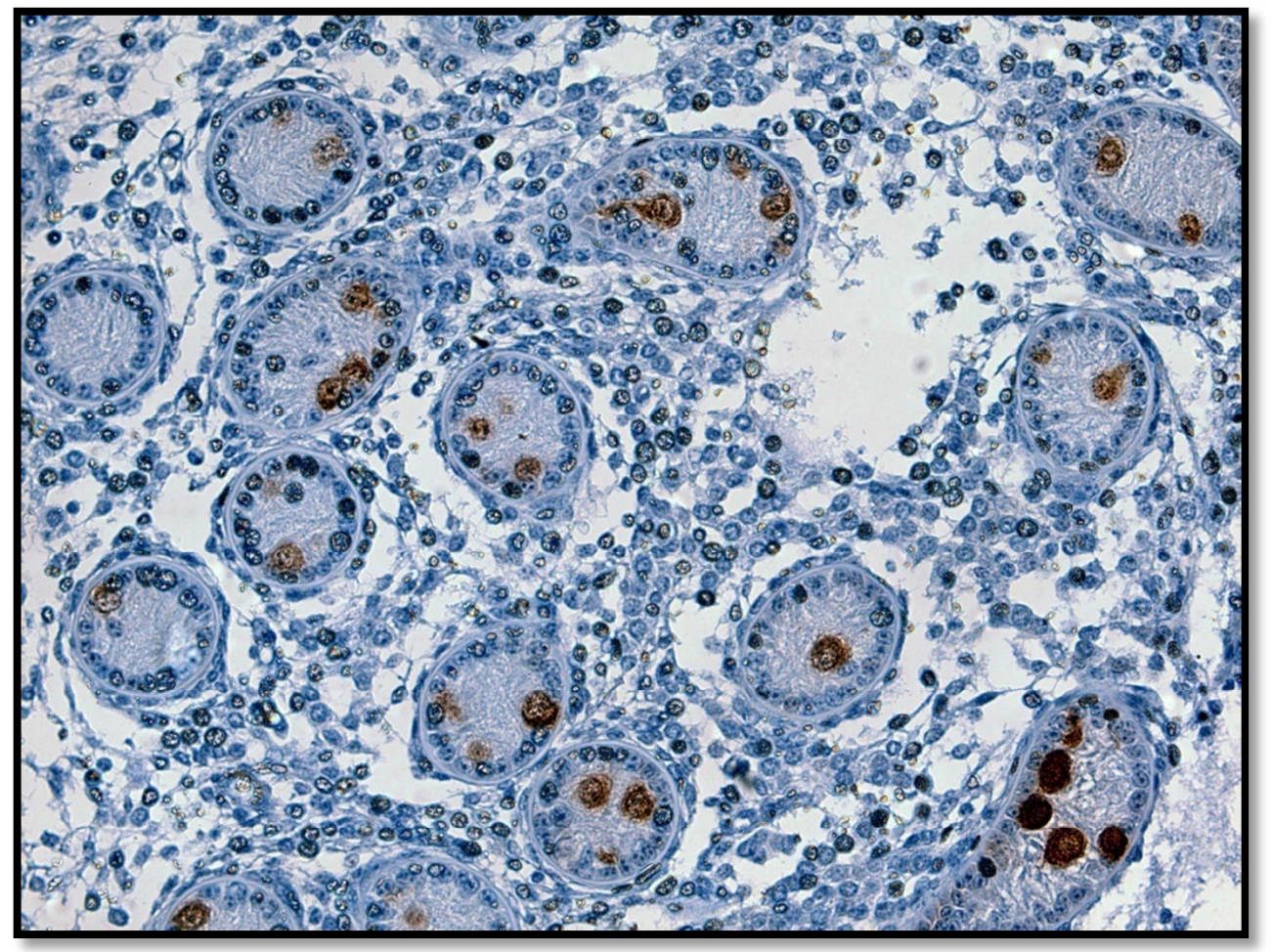


Figura 26 - Fotografias de microscopia de epifluorescência de amostras do testículo doador de células espermatogoniais de bezerros pré-púberes da raça Nelore submetidas à incubação com DBA conjugada ao FITC. Núcleos celulares marcados com Hoechst (azul) (A), células marcadas com DBA (verde) (B) e sobreposição das imagens A e B (C) (Magnificação de 400 x)

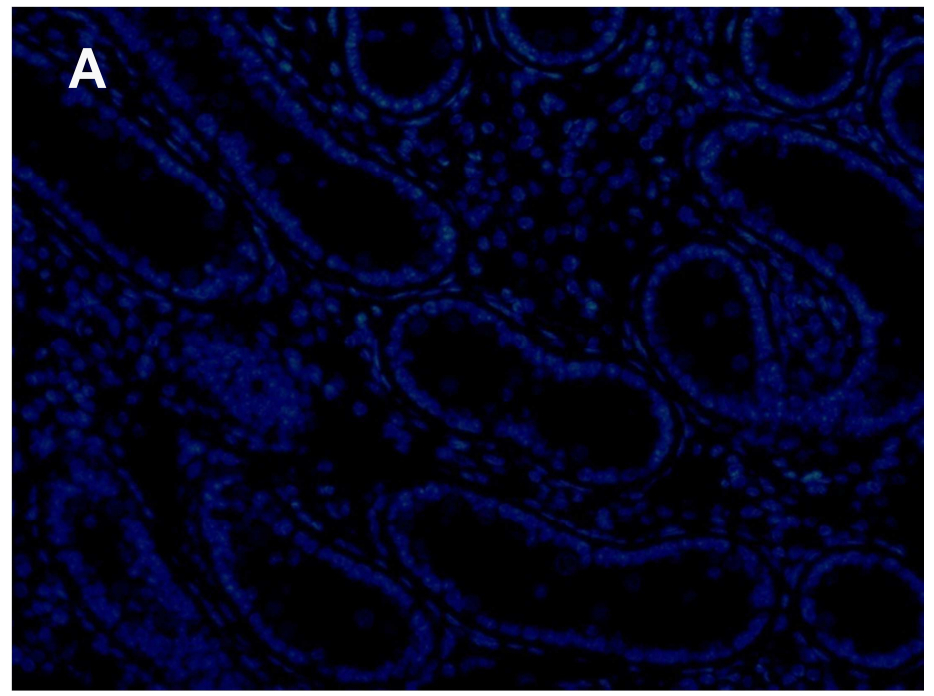

B 


\subsection{DISCUSSÃO}

O principal objetivo deste trabalho foi estudar a capacidade de SSCs transgênicas em integrar-se aos túbulos seminíferos de bezerros pré-púberes da raça Nelore após transplante autólogo. Primeiramente, células espermatogoniais foram isoladas com sucesso por digestão enzimática do parênquima do testículo doador. Com base nos resultados do Capítulo 1 em relação aos métodos de purificação por plaqueamento diferencial e gradiente descontínuo de Percoll, decidiu-se por não purificar as células espermatogoniais de animais pré-púberes. Dessa forma, não foram obtidas populações puras de SSCs a partir das células isoladas. Adotou-se, então, o termo células espermatogoniais para todas as células isoladas, cultivadas in vitro, transformadas com o vetor Lac $Z$ e finalmente transplantadas aos testículos receptores. Embora tenha sido eleito o transplante de células espermatogoniais, sabe-se que foram transplantadas SSCs, pois a caracterização das células isoladas demonstrou a expressão dos marcadores de SSCs ITGA6, GFRa-1, PGP9.5 e afinidade pela lectina DBA. Após 45 dias do transplante autólogo das células espermatogoniais LacZ+, foi possível observar a presença de células viáveis expressando o gene marcador nos testículos receptores de todos os animais pertencentes aos grupos 1 e 2, ou seja, que receberam células transgênicas. Nenhuma das células transgênicas observadas nos testículos transplantados estava integrada aos túbulos seminíferos. Todas as células LacZ positivas foram observadas no interstício das amostras positivas avaliadas. Junto ao gene marcador LacZ, foi utilizado o corante de rastreamento celular PKH26 (Grupos 1 e 3) para observar as células transplantadas. Contudo, este corante não foi útil para este propósito, visto que não foi possível distinguir as células transplantadas marcadas das demais células do testículo receptor. 


\subsubsection{Isolamento e cultivo in vitro de células espermatogoniais de bovinos pré-púberes}

A técnica adotada para 0 isolamento das células espermatogoniais de bezerros pré-púberes foi adaptada do protocolo descrito por Reding et al. (2010). Este protocolo difere do protocolo descrito no Capítulo 1, utilizado para isolamento de células espermatogoniais de bovinos adultos, baseado no descrito por Izadyar et al. (2002). Embora tenha sido possível isolar e cultivar in vitro células espermatogoniais de bovinos adultos no Capítulo 1, o protocolo adotado não permitiu cultivo prolongado, além de oferecer baixa repetibilidade nos dados de viabilidade celular após o plaqueamento diferencial. Muitas manipulações foram descartadas por não oferecer quantidade de células viáveis suficiente para caracterização celular ou transdução com o vetor lentiviral (dados não apresentados). Assim, a diferença entre os dois protocolos que suscitou sua troca neste trabalho foi o soro no cultivo in vitro de SSCs. Reding et al. (2010) utilizou BSA na composição do meio de cultivo ao invés de FCS e Oatley ${ }^{2}$ (2011) afirma que o FCS é prejudicial à SSCs bovinas quando cultivadas in vitro (informação verbal). Em 2004, Kubota e colaboradores levantaram a questão sobre o uso de FCS em cultivo de SSCs em relação à variabilidade observada entre os diferentes lotes de FCS, além da presença de muitos fatores desconhecidos que em altas concentrações podem ser tóxicos a certos tipos celulares (BARNES; SATO, 1980). Eles testaram várias condições de cultivo in vitro de SSCs e reportaram que os sistemas de cultivo sem adição FCS ofereceram melhores condições para SSCs murinas serem mantidas in vitro por, pelo menos, 1 semana (KUBOTA; AVARBOCK; BRINSTER, 2004b). Visto que no presente trabalho as células espermatogoniais foram cultivadas in vitro por, no máximo, $60 \mathrm{~h}$, optou-se pela troca do protocolo de isolamento e cultivo in vitro para garantir boa qualidade das células transplantadas. De fato, foi possível observar alta viabilidade celular após o após o plaqueamento diferencial (D1), ou seja, após 12-18 h de cultivo in vitro, além da obtenção de quantidade suficiente de células para a execução de todas as etapas do experimento.

\footnotetext{
${ }^{2}$ Informação fornecida por Oatley, J. em Portland, OR, EUA, em 2011.
} 
Os resultados com o plaqueamento diferencial na purificação de células espermatogoniais de animais adultos, descritos no Capítulo 1, não confirmaram a eficácia desta técnica na purificação de SSCs. Contudo, decidiu-se por manter este procedimento após o isolamento de células espermatogoniais de animais prépúberes para que houvesse renovação do meio de cultivo, além de permitir a avaliação da viabilidade das células após 12-18 h de cultivo in vitro.

\subsubsection{Verificação da integração de células espermatogoniais LacZ+ e/ou marcadas com PKH26 aos túbulos seminíferos de bovinos pré-púberes da raça Nelore após transplante autólogo}

Tanto a orquiectomia unilateral do testículo doador quanto o método de injeção das células espermatogoniais no testículo receptor não causou injúrias ao testículo receptor. Não foram observados sinais de inflamação aguda no momento do transplante, como aumento de volume, temperatura ou sensibilidade à palpação. Não foram observados sinais de degeneração testicular ou inflamação crônica, como enrijecimento, fibrose ao remover o testículo receptor. Tais observações sugerem que a orquiectomia unilateral seguida de injeção intratesticular na região do mediastino podem ser consideradas inócuas para o transplante de células germinativas. Contudo, será discutida mais adiante sua eficácia para a colonização dos túbulos seminíferos pelas células transplantadas.

Após a segunda orquiectomia, amostras de tecido foram submetidas a dois tipos de processamento para a verificar a presença de células espermatogoniais LacZ+ e/ou marcadas com PKH26 após 45 dias de transplante. A primeira técnica utilizou uma solução contendo paraformaldeído como fixador e inclusão em parafina após reação de x-gal nas amostras de tecido. Foi utilizado o protocolo descrito por Mercer et al. (1991) para tecido nervoso, que foi reproduzido em amostras de testículos de camundongo em 1994 por Brinster e Zimmermann. Este protocolo não foi eficaz para permitir a visualização de células transgênicas no testículo transplantado. Neste protocolo, as amostras de tecido permaneceram em solução 
com o corante de $\mathrm{x}$-gal por $2 \mathrm{~h}$. Acredita-se que este tempo não foi suficiente para que houvesse completa penetração no tecido, permitindo a marcação de células beta-galactosidase positivas. $\mathrm{O}$ outro protocolo utilizou o glutaraldeído como fixador e as amostras foram incluídas em resina para criostato. Neste segundo protocolo, as amostras permaneceram $4 \mathrm{~h}$ em solução com corante de x-gal. Embora não tenha sido possível preservar adequadamente a morfologia do tecido, a segunda técnica permitiu visualizar as células LacZ+ transplantadas.

Assim, foi possível verificar o sucesso da transdução das células espermatogoniais com o vetor lentiviral LV-LacZ assim como do seu transplante autólogo em testículos de bezerros pré-púberes da raça Nelore. Contudo, não foi possível observar nenhuma célula transgênica dentro dos túbulos seminíferos nas amostras examinadas. Todas as células encontravam-se no interstício, ou seja, espaço compreendido entre os túbulos seminíferos. Dessa forma, não é possível afirmar que o transplante foi bem sucedido para a introdução de células transgênicas nos túbulos seminíferos destes animais.

A partir da observação destes resultados, várias questões sobre as possíveis causas deste insucesso surgiram, sendo a primeira a técnica de transplante. $O$ primeiro transplante de SSCs reportado foi realizado em camundongos, em estudo onde SSCs de animais férteis foram transplantadas para o testículos de animais inférteis, resultando na produção de espermatozoides pelos receptores (BRINSTER; ZIMMERMANN, 1994). Esses espermatozoides produzidos pelos animais receptores eram viáveis e férteis, comprovados por fecundação in vivo e in vitro (BRINSTER; AVARBOCK, 1994). A partir de então, o transplante de SSCs passou a ser utilizado como prova incontestável da preservação da função das SSCs cultivadas in vitro, sendo até hoje, considerada indispensável para este propósito. Neste contexto, e tendo em conta que no presente trabalho não foram observadas células LacZ+ nos túbulos seminíferos dos animais receptores, pode-se formular a hipótese que as células espermatogoniais LacZ+ observadas nos cortes histológicos não eram SSCs, não podendo, assim, integrar-se aos túbulos seminíferos do testículo receptor. Devido à limitação da quantidade de partículas virais utilizadas na transdução das células transplantadas, decidiu-se não coletar amostras de células espermatogoniais transduzidas para verificar as SSCs LacZ+ por reação de imunofluorescência, pois do contrário seria necessário quantidade extra de vírus 
muito grande, tornando sua produção inviável. Dessa forma, não foi possível determinar se o vetor lentiviral transformou as SSCs presentes na população de células transplantadas ou somente as demais células espermatogoniais mais diferenciadas. Outra maneira de verificar se as células espermatogoniais LacZ+ observadas nos cortes histológicos das amostras de tecido dos testículos transplantados são SSCs é a verificação da expressão de marcadores de SSCs por imunohistoquímica destas amostras. Tal análise não foi realizada, contudo, as amostras de tecido incluídas em OCT encontram-se armazenadas para realização de imunohistoquímica para detecção de PGP9.5. Esta análise será útil não apenas para estudar a hipótese supracitada como também a de que as células espermatogoniais LacZ+ observadas nos cortes histológicos são SSCs, mas a injeção intratesticular não favoreceu sua distribuição pela rete testes, sendo incapaz de alcançar o interior dos túbulos seminíferos. As células espermatogoniais foram transplantadas com a injeção intratesticular na região do mediastino, guiada por imagem ultrassonográfica. A observação de células transplantadas nos testículos receptores sugere que a técnica é suficiente para a introdução ou transplante das células. Mas sua ausência nos túbulos seminíferos sugere que não é suficiente para sua participação na espermatogênese, o qual compõe o objetivo principal deste trabalho. Afinal, pretendia-se estabelecer nova ferramenta para produção de bovinos transgênicos. A técnica adotada no presente trabalho reproduziu o reportado por Kaul, Kaur e Rafeeqi (2010), em caprinos. Utilizando a injeção intratesticular guiada por ultrassonografia de SSCs marcadas com o corante $\mathrm{PKH} 26$, puderam observar células marcadas nos túbulos seminíferos de todos os animais transplantados por até 12 semanas. Contudo, não foi realizado nenhum estudo sobre a participação ou não destas células na espermatogênese dos animais receptores.

No presente trabalho, foi utilizado o corante de rastreamento celular PKH26 para facilitar a identificação das células espermatogoniais transplantadas após a orquiectomia final dos bezerros. Tal marcação seria importante caso as células LacZ+ (células que expressam LacZ antes do transplante) não expressassem o gene marcador após o transplante. É comum observar células transgênicas expressarem o gene exógeno em condições in vitro, mas o deixarem de fazer depois de transplantadas para tecidos vivos. A eficácia do corante PKH26 já foi verificada na espécie bovina, in vitro e in vivo, em experimentos realizados por Herrid et al. 
(2006 e 2009). Em ambos os trabalhos foram transplantadas SSCs bovinas entre animais zebuínos e taurinos, sendo o corante identificado em células dos testículos receptores por até 6 meses após o transplante. No presente trabalho, não foi possível atingir o objetivo de rastreamento das células transplantadas com este corante. Ao examinar as lâminas de amostras dos testículos transplantados, a autofluorescência do tecido impossibilitou a visualização das células marcadas com PKH26. Esta autofluorescência foi observada tanto nas amostras processadas em parafina quanto nas incluídas em resina para corte em criostato.

Se a marcação das células espermatogoniais com PKH26 pudesse ter sido observada nos cortes histológicos das amostras de testículos transplantados, poderse-ia verificar a hipótese que as SSCs presentes na população de células transplantadas integraram-se aos túbulos seminíferos mas pararam de expressar o gene marcador LacZ, não sendo possível sua detecção.

Outro ponto importante que deve ser discutido a partir destes resultados é a importância da supressão da espermatogênese nos testículos receptores. Muitos estudos com transplante de SSCs utilizam a supressão da espermatogênese antes do transplante. Assim, a gônada se tornaria mais susceptível a aceitar a integração das células transplantadas. Dentre as técnicas mais utilizadas para a supressão da espermatogênese podemos citar a irradiação da gônada e administração de drogas, como o busulfan. Optou-se pela não realização da supressão da espermatogênese pelo tipo de transplante adotado, o autólogo. Para a realização do transplante autólogo, a remoção da espermatogênese impediria a obtenção de células espermatogoniais viáveis para o cultivo in vitro, transformação genética e transplante. Para que seja possível transplantar células espermatogoniais para um testículo sem espermatogênese, deve-se adotar o transplante homólogo, ou seja, entre indivíduos diferentes da mesma espécie. Contudo, estudos prévios com transplante de SSCs em bovinos apontaram o transplante autólogo com melhores taxas de sucesso. Como o objetivo final deste trabalho era o estabelecimento de uma técnica viável de transgenia animal, o transplante autólogo possui maior potencial. Além disso, foram escolhidos bezerros pré-púberes com o objetivo de facilitar a integração das células transplantadas visto que estes animais ainda não realizam espermatogênese. Esta hipótese não pôde ser comprovada, já que não foi observada integração das células transplantadas aos túbulos seminíferos. 
CONCLUSÕES 


\section{CONCLUSÕES}

\section{Capítulo 1}

Foi possível isolar e cultivar in vitro células espermatogoniais de bovinos adultos.

Tanto o plaqueamento diferencial quanto o gradiente descontínuo de Percoll não foram satisfatórios na obtenção de populações puras de SSCs de bovinos adultos.

Foi detectada a expressão gênica por PCR em tempo real de ITGA6, GFRa-1 e PGP9.5 nas células espermatogoniais de bovinos adultos, confirmando a presença de SSCs.

Foi identificada pela primeira vez a expressão de alfa- 6 integrina em células espermatogoniais bovinas.

O corante de rastreamento celular $\mathrm{PKH} 26$ corou satisfatoriamente as células espermatogoniais cultivadas in vitro.

Foi possível produzir células espermatogoniais de bovinos adultos LacZ+com o vetor lentiviral LV-LacZ.

É possível preencher o mediastino de testículos bovinos adultos com injeção de $5 \mathrm{~mL}$ de corante azul de tripan guiada por ultrassonografia. 


\section{Capítulo 2}

Foi possível isolar e cultivar in vitro células espermatogoniais de bezerros prépúberes.

A injeção intratesticular de células espermatogoniais LacZ+ no mediastino de bezerros pré-púberes não permite observar a integração das células transgênicas transplantadas aos túbulos seminíferos.

A técnica de injeção intratesticular de células espermatogoniais LacZ+ no mediastino de bezerros pré-púberes permite observar células transgênicas transplantadas no testículo receptor, situadas fora dos túbulos seminíferos.

A expressão gênica por RT-PCR em tempo real de ITGA6, GFRa-1 e PGP9.5 foi detectada nas espermatogoniais de bezerros pré-púberes, confirmando a presença de SSCs. 


\section{REFERÊNCIAS}




\section{REFERÊNCIAS}

APONTE, P. M.; SODA, T.; VAN DE KANT, H. J. G.; DE ROOIJ, D. G. Basic features of bovine spermatogonial culture and effects of glial cell line-derived neurotrophic factor. Theriogenology, v. 65, n., p. 1828-1847, 2006.

BARNES, D.; SATO, G. Serum-free cell culture: a unifying approach. Cell, v. 22, n. 3, p. $649-655,1980$.

BELLVÉ, A. R.; CAVICCHIA, J. C.; MILLETFE, C. F.; BRIEN, D. A. O.; BHATNAGAR, Y. M.; DYM, M. SPERMATOGENIC CELLS OF THE PREPUBERAL MOUSE Isolation and Morphological Characterization From the Departments of Physiology and Anatomy and the Laboratory of Human Reproduction and. Cell, v. 74, n., p. 68-85, 1977.

BI, C. M.; ZHANG, S. Q.; ZHANG, Y.; PENG, S. Y.; WANG, L.; AN, Z. X.; QI, A.; LV, $\mathrm{N}$. Immortalization of bovine germ line stem cells by c-myc and hTERT. Anim Reprod Sci, v. 100, n., p. 371-378, 2007.

BRAUN, R. E.; BEHRINGER, R. R.; PESCHON, J. J.; BRINSTER, R. L.; PALMITER, R. D. Genetically haploid spermatids are phenotypically diploid. Nature, v. 337, n. 6205, p. 373-376, 1989.

BRINSTER, R. L.; ZIMMERMANN, J. W. Spermatogenesis following male germ-cell transplantation. Proceedings of the National Academy of Sciences, v. 91, n., p. 11298, 1994.

BRINSTER, R. L.; AVARBOCK, M. R. Germline transmission of donor haplotype following spermatogonial transplantation. Proceedings of the National Academy of Sciences, v. 91, n., p. 11303, 1994.

BYSKOV, A. G.; HØYER, P. E. Embryology of mammalian gonads and ducts. In: Knobil, E. e Neill, J. D. (Ed.). Phisiology of Reproduction. New York: Raven, 1994. v.1, p.487-540.

DE KRETSER, D. M.; KERR, J. B. Cytology of the testis. In: Knobil, E. e Neill, J. D. (Ed.). The physiology of reproduction. New York: Raven, 1994. v.2, p.1177-1290.

DE ROOIJ, D. G. Stem cells in the testis. International journal of experimental pathology, v. 79, n., p. 67, 1998.

DE ROOIJ, D. G.; RUSSELL, L. D. All you wanted to know about spermatogonia but were afraid to ask. J Androl, v. 21, n. 6, p. 776-798, 2000.

DE ROOIJ, D. G.; MIZRAK, S. C. Deriving multipotent stem cells from mouse spermatogonial stem cells: a new tool for developmental and clinical research. Development, v. 135, n., p. 2207, 2008. 
DETTIN, L.; RAVINDRANATH, N.; HOFMANN, M. C.; DYM, M. Morphological characterization of the spermatogonial subtypes in the neonatal mouse testis. Biol Reprod, v. 69, n., p. 1565, 2003.

DOBRINSKI, I.; AVARBOCK, M. R.; BRINSTER, R. L. Germ cell transplantation from large domestic animals into mouse testes. Mol Reprod Dev, v. 57, n., p. 270-279, 2000.

DOBRINSKI, I. Germ cell transplantation and testis tissue xenografting in domestic animals. Anim Reprod Sci, v. 89, n., p. 137-145, 2005.

ERTL, C.; WROBEL, K. H. Distribution of sugar residues in the bovine testis during postnatal ontogenesis demonstrated with lectin-horseradish peroxidase conjugates. Histochemistry, v. 97, n., p. 161-171, 1992.

EVANS, M. J.; KAUFMAN, M. H. Establishment in culture of pluripotential cells from mouse embryos. Nature, v. 292, n., p. 154-156, 1981.

FÉNICHEL, P.; DURAND-CLÉMENT, M. Role of integrins during fertilization in mammals. Human reproduction (Oxford, England), v. 13 Suppl 4, n., p. 31-46, 1998.

FURIMSKY, A.; VUONG, N.; XU, H.; KUMARATHASAN, P.; XU, M.; WEERACHATYANUKUL, W.; BOU KHALIL, M.; KATES, M.; TANPHAICHITR, N. Percoll gradient-centrifuged capacitated mouse sperm have increased fertilizing ability and higher contents of sulfogalactosylglycerolipid and docosahexaenoic acidcontaining phosphatidylcholine compared to washed capacitated mouse sperm. Biol Reprod, v. 72, n., p. 574-583, 2005.

GANDOLFI, F. Spermatozoa, DNA binding and transgenic animals. Transgenic research, v. 7, n., p. 147-155, 1998.

GASSEI, K.; EHMCKE, J.; SCHLATT, S. Efficient enrichment of undifferentiated GFR alpha $1+$ spermatogonia from immature rat testis by magnetic activated cell sorting. Cell Tissue Res, v. 337, n., p. 177-183, 2009.

GOLDEN, J.; DEMARO, J.; OSBORNE, P. Expression of neurturin, GDNF, and GDNF family-receptor mRNA in the developing and mature mouse. Experimental, v. 158, n., p. 504-528, 1999.

GUAN, K.; NAYERNIA, K.; MAIER, L.; WAGNER, S. Pluripotency of spermatogonial stem cells from adult mouse testis. Nature, v. 440, n., p. 1199-1203, 2006.

HAHNEL, A.; EDDY, E. The distribution of two cell surface determinants of mouse embryonal carcinoma and early embryonic cells. Journal of Reproductive Immunology, v. 10, n., p. 89-110, 1987. 
HAMMER, R. E.; PURSEL, V. G.; REXROAD, C. E.; WALL, R. J.; BOLT, D. J.; EBERT, K. M.; PALMITER, R. D.; BRINSTER, R. L. Production of transgenic rabbits, sheep and pigs by microinjection. Nature, v. 315, n., p. 680-683, 1985.

HERRID, M.; DAVEY, R. J.; HILL, J. R. Characterization of germ cells from prepubertal bull calves in preparation for germ cell transplantation. Cell Tissue Res, v. 330, n., p. 321-329, 2007.

HERRID, M.; DAVEY, R. J.; HUTTON, K.; COLDITZ, I. G.; HILL, J. R. A comparison of methods for preparing enriched populations of bovine spermatogonia. Reproduction, Fertility and Development, v. 21, n., p. 393-399, 2009.

HOFMANN, M. C.; BRAYDICH-STOLLE, L.; DYM, M. Isolation of male germ-line stem cells; influence of GDNF. Dev Biol, v. 279, n., p. 114-124, 2005.

HOFMANN, M. C. Gdnf signaling pathways within the mammalian spermatogonial stem cell niche. Mol Cell Endocrinol, v. 288, n., p. 95-103, 2008.

HUANG, S.; SARTINI, B. L.; PARKS, J. E. Spermatogenesis in testis xenografts grafted from pre-pubertal Holstein bulls is re-established by stem cell or early spermatogonia. Anim Reprod Sci, v. 103, n., p. 1-12, 2008.

HUCKINS, C. The spermatogonial stem cell population in adult rats. I. Their morphology, proliferation and maturation. Anat Rec, v. 169, n. 3, p. 533-557, 1971.

HUCKINS, C.; OAKBERG, E. F. Morphological and quantitative analysis of spermatogonia in mouse testes using whole mounted seminiferous tubules, I. The normal testes. The Anatomical record, v. 192, n., p. 519-528, 1978a.

HUCKINS, C.; OAKBERG, E. F. Morphological and quantitative analysis of spermatogonia in mouse testes using whole mounted seminiferous tubules. II. The irradiated testes. The Anatomical record, v. 192, n., p. 529-542, 1978b.

HYNES, R. Integrins: versatility, modulation, and signaling in cell adhesion. Cell, v. 69, n., p. 11-25, 1992.

IZADYAR, F.; SPIERENBERG, G.; CREEMERS, L.; OUDEN, K.; DE ROOIJ, D. Isolation and purification of type $A$ spermatogonia from the bovine testis. Reproduction (Cambridge, England), v. 124, n., p. 85-94, 2002.

IZADYAR, F.; OUDEN, K. D.; CREEMERS, L. Proliferation and differentiation of bovine type A spermatogonia during long-term culture. Biology of, v. 281, n., p. 272$281,2003$.

IZADYAR, F.; WONG, J.; MAKI, C.; PACCHIAROTTI, J.; RAMOS, T.; HOWERTON, K.; YUEN, C.; GREILACH, S.; ZHAO, H. H.; CHOW, M.; CHOW, Y. C.; RAO, J.; BARRITT, J.; BAR-CHAMA, N.; COPPERMAN, A. Identification and characterization of repopulating spermatogonial stem cells from the adult human testis. Human, v. 26, n., p. 1296-1306, 2011. 
KANATSU-SHINOHARA, M. Restoration of fertility in infertile mice by transplantation of cryopreserved male germline stem cells. Human Reproduction, v. 18, n., p. 26602667, 2003.

KANATSU-SHINOHARA, M.; TOYOKUNI, S.; SHINOHARA, T. CD9 is a surface marker on mouse and rat male germline stem cells. Biol Reprod, v. 70, n., p. 70-75, 2004.

KANATSU-SHINOHARA, M.; INOUE, K.; LEE, J.; YOSHIMOTO, M.; OGONUKI, N.; MIKI, H.; BABA, S.; KATO, T.; KAZUKI, Y.; TOYOKUNI, S.; OTHERS. Generation of pluripotent stem cells from neonatal mouse testis. Cell, v. 119, n., p. 1001-1012, 2004.

KAUL, G.; KAUR, J.; RAFEEQI, T. A. Ultrasound guided transplantation of enriched and cryopreserved spermatogonial cell suspension in goats. Reprod Domest Anim, v. 45, n., p. e249-254, 2010.

KUBOTA, H.; AVARBOCK, M. R.; BRINSTER, R. L. Growth factors essential for selfrenewal and expansion of mouse spermatogonial stem cells. Proc Natl Acad Sci U S A, v. 101, n., p. 16489, 2004a.

KUBOTA, H.; AVARBOCK, M. R.; BRINSTER, R. L. Culture conditions and single growth factors affect fate determination of mouse spermatogonial stem cells. Biol Reprod, v. 71, n., p. 722, 2004b.

KUES, W. A.; NIEMANN, H. The contribution of farm animals to human health. Trends Biotechnol, v. 22, n., p. 286-294, 2004.

KUIJK, E. W.; COLENBRANDER, B.; ROELEN, B. A. J. The effects of growth factors on in vitro-cultured porcine testicular cells. Reproduction, v. 138, n., p. 721, 2009.

LAVITRANO, M.; BACCI, M. L.; FORNI, M.; LAZZERESCHI, D.; DI STEFANO, C.; FIORETTI, D.; GIANCOTTI, P.; MARFÉ, G.; PUCCI, L.; RENZI, L.; OTHERS. Efficient production by sperm-mediated gene transfer of human decay accelerating factor (hDAF) transgenic pigs for xenotransplantation. Proceedings of the National Academy of Sciences, v. 99, n., p. 14230, 2002.

LAWSON, K. A.; PEDERSEN, R. A. Clonal analysis of cell fate during gastrulation and early neurulation in the mouse. Ciba Found Symp, v. 165, n., p. 3-21; discussion 21-26, 1992.

LAWSON, K. A.; HAGE, W. J. Clonal analysis of the origin of primordial germ cells in the mouse. Ciba Found Symp, v. 182, n., p. 68-84; discussion 84-91, 1994.

LEE, D. R.; KAPROTH, M. T.; PARKS, J. E. In vitro production of haploid germ cells from fresh or frozen-thawed testicular cells of neonatal bulls. Biol Reprod, v. 65, n., p. 873, 2001. 
LEE, K.; HAUGEN, H. S.; CLEGG, C. H.; BRAUN, R. E. Premature translation of protamine $1 \mathrm{mRNA}$ causes precocious nuclear condensation and arrests spermatid differentiation in mice. Proc Natl Acad Sci U S A, v. 92, n. 26, p. 12451-12455, 1995.

MEISTRICH, M. L.; VAN BEEK, M. Spermatogonial Stem cells. In: Desjardins, C. e Ewing, L. L. (Ed.). Cell and molecular biology of the testis. New York: Oxford Univ. Press., 1993, p.266-295.

MENG, X.; LINDAHL, M.; HYVONEN, M., PARVINEN, M., DE ROOIJ, D.G., HESS, M. W., RAATIKAINEN-AHOKAS, A., SAINIO, K., RAUVALA, H., LAKSO, M., PICHEL, J. G., WESTPHAL, H., SAARMA, M., SARIOLA, H. Regulation of Cell Fate Decision of Undifferentiated Spermatogonia by GDNF. Science, v. 287, n., p. 14891493, 2000.

MERCER, E. H.; HOYLE, G. W.; KAPUR, R. P.; BRINSTER, R. L.; PALMITER, R. D. The dopamine beta-hydroxylase gene promoter directs expression of $\mathrm{E}$. coli lacZ to sympathetic and other neurons in adult transgenic mice. Neuron, v. 7, n. 5, p. 703716, 1991.

NAGANO, M.; AVARBOCK, M. R.; LEONIDA, E. B.; BRINSTER, C. J.; BRINSTER, R. L. Culture of mouse spermatogonial stem cells. Tissue Cell, v. 30, n. 4, p. 389397, 1998.

NAGANO, M.; RYU, B.-Y.; BRINSTER, C. J.; AVARBOCK, M. R.; BRINSTER, R. L. Maintenance of mouse male germ line stem cells in vitro. Biol Reprod, v. 68, n., p. 2207-2214, 2003.

NAVIAUX, R. K.; COSTANZI, E.; HAAS, M.; VERMA, I. M. The pCL vector system: rapid production of helper-free, high-titer, recombinant retroviruses. Journal of virology, v. 70, n., p. 5701, 1996.

OATLEY, J. M.; AVILA, D. M. D.; MCLEAN, D. J.; GRISWOLD, M. D.; REEVES, J. J. Transplantation of bovine germinal cells into mouse testes The online version of this article, along with updated information and services, is located on the World Wide Web at : Transplantation of bovine germinal cells into mouse testes. Journal of Animal Science, v., n., p. 1925-1931, 2002.

OATLEY, J. M.; REEVES, J. J.; MCLEAN, D. J. Biological activity of cryopreserved bovine spermatogonial stem cells during in vitro culture. Biol Reprod, v. 71, n., p. 942, 2004.

OATLEY, J. M.; BRINSTER, R. L. Regulation of spermatogonial stem cell selfrenewal in mammals. Annu Rev Cell Dev Biol, v. 24, n., p. 263-286, 2008.

ORWIG, K. E.; SHINOHARA, T.; AVARBOCK, M. R.; BRINSTER, R. L. Functional analysis of stem cells in the adult rat testis. Biol Reprod, v. 66, n. 4, p. 944-949, 2002. 
REDING, S. C.; STEPNOSKI, A. L.; CLONINGER, E. W.; OATLEY, J. M. THY1 is a conserved marker of undifferentiated spermatogonia in the pre-pubertal bull testis. Reproduction, v. 139, n. 5, p. 893-903, 2010.

RUSSELL, L. D. Histopathological Evaluation of the Testis. In: Russell, L. D., Ettlin, R. A., et al (Ed.). Histological and Histopathological Evaluation of the Testis. Clearwater, FL.: Cache River Press, 1990, p.119-161.

SALANOVA, M.; STEFANINI, M.; DE CURTIS, I.; PALOMBI, F. Integrin receptor alpha 6 beta 1 is localized at specific sites of cell-to-cell contact in rat seminiferous epithelium. Biol Reprod, v. 52, n., p. 79-87, 1995.

SEANDEL, M.; JAMES, D.; SHMELKOV, S. V.; FALCIATORI, I.; KIM, J.; CHAVALA, S.; SCHERR, D. S.; ZHANG, F.; TORRES, R.; GALE, N. W.; OTHERS. Generation of functional multipotent adult stem cells from GPR125+ germline progenitors. Nature, v. 449, n., p. 346-350, 2007.

SHINOHARA, T.; AVARBOCK, M.; BRINSTER, R. L. beta1- and alpha6-integrin are surface markers on mouse spermatogonial stem cells. Proceedings of the National Academy of Sciences, v. 96, n., p. 5504-5509, 1999.

SHINOHARA, T.; AVARBOCK, M.; BRINSTER, R. Functional analysis of spermatogonial stem cells in Steel and cryptorchid infertile mouse models. Dev Biol, v. 220, n., p. 401-411, 2000.

SIMON, L.; EKMAN, G. C.; TYAGI, G.; HESS, R. A.; MURPHY, K. M.; COOKE, P. S. Common and distinct factors regulate expression of mRNA for ETV5 and GDNF, Sertoli cell proteins essential for spermatogonial stem cell maintenance. Exp Cell Res, v. 313, n. 14, p. 3090-3099, 2007.

STOCKWELL, S.; HERRID, M.; DAVEY, R.; BROWNLEE, A.; HUTTON, K.; HILL, J. $R$. Microsatellite detection of donor-derived sperm DNA following germ cell transplantation in cattle. Reproduction, Fertility and Development, v. 21, n., p. 462-468, 2009.

TAGELENBOSCH, R. A. J.; DE ROOIJ, D. G. A quantitative study of spermatogonial multiplication and stem cell renewal in the $\mathrm{C} 3 \mathrm{H} / 101 \mathrm{~F} 1$ hybrid mouse. Mutation Research/Fundamental and Molecular Mechanisms of Mutagenesis, v. 290, n., p. 193-200, 1993.

TRUPP, M.; RYDÉN, M.; JÖRNVALL, H.; FUNAKOSHI, H.; TIMMUSK, T.; ARENAS, E.; IBÁÑEZ, C. F. Peripheral expression and biological activities of GDNF, a new neurotrophic factor for avian and mammalian peripheral neurons. J Cell Biol, v. 130, n., p. 137-148, 1995.

VAN PELT, A.; MORENA, A. R.; VAN DISSEL-EMILIANI, F.; BOITANI, C.; GAEMERS, I. C.; DE ROOIJ, D. G.; STEFANINI, M. Isolation of the synchronized A spermatogonia from adult vitamin A-deficient rat testes. Biol Reprod, v. 55, n., p. 439, 1996. 
WROBEL, K.-H.; BICKEL, D.; KUJAT, R.; SCHIMMEL, M. Configuration and distribution of bovine spermatogonia. Cell Tissue Res, v. 279, n., p. 277-289, 1995. 
ANEXOS

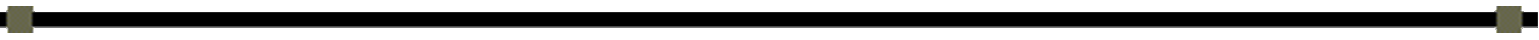




\section{ANEXO A - DMEM digestão}

e DMEM (Invitrogen; cat: 11965-092)

- 14 mM NaHCO 3 (Sigma; cat: S5761)

- 4 mM L-glutamina (Sigma; cat: G8540)

- 15 mM de Hepes (Sigma; cat: H6147)

- $1 \%$ (v/v) solução de aminoácidos não-essenciais (Sigma; cat: M7145)

e $100 \mathrm{UI} / \mathrm{mL}$ de penicilina (Sigma; cat: P3032)

• $100 \mu \mathrm{g} / \mathrm{mL}$ de estreptomicina (Sigma; cat: S6501)

- $40 \mu \mathrm{g} / \mathrm{mL}$ de gentamicina (Sigma; cat: G1264)

- $1 \mathrm{mg} / \mathrm{mL}$ de hialuronidase tipo I (Sigma; cat: H3506)

- $1 \mathrm{mg} / \mathrm{mL}$ de colagenase (Sigma; cat: C9263)

- $1 \mathrm{mg} / \mathrm{mL}$ de tripsina (Gibco; cat: 27250-018) 


\section{ANEXO B - DMEM cultivo}

e DMEM (Invitrogen; cat: 11965-092)

- 14 mM NaHCO 3 (Sigma; cat: S5761)

- 4 mM L-glutamina (Sigma; cat: G8540)

- 15 mM de Hepes (Sigma; cat: H6147)

- $1 \%(v / v)$ solução de aminoácidos não-essenciais (Sigma; cat: M7145)

e $100 \mathrm{UI} / \mathrm{mL}$ de penicilina (Sigma; cat: P3032)

• 100 Mg/ mL de estreptomicina (Sigma; cat: S6501)

- $40 \mu \mathrm{g} / \mathrm{mL}$ de gentamicina (Sigma; cat: G1264)

- $10 \%$ (v/v) FCS (Gibco; cat: 12657-029) 


\section{ANEXO C - Ensaio X-gal}

- 0,1 mM NaPO 4 (Invitrogen; cat: 11965-092)

- 3 mM K3 (Sigma; cat: P8131)

- 3 mM K4 (Sigma; cat: P3289)

- $1 \mathrm{mg} / \mathrm{mL}$ X-gal (Boehringer Mannheim; cat: 745-740)

• 1,2 $\mathrm{mM} \mathrm{MgCl}_{2}$ (Sigma; cat: M8266) 


\section{ANEXO D - DMEM digestão 1}

- DMEM (Invitrogen; cat: 11965-092)

- 1,1163mg/ mL $\mathrm{NaHCO}_{3}$ (Sigma; cat: S5761)

• 0,5846 mg/ mL L-glutamina (Sigma; cat: G8540)

e $1 \%(v / v)$ solução de aminoácidos não-essenciais (Sigma; cat: M7145)

e $100 \mathrm{UI} / \mathrm{mL}$ de penicilina (Sigma; cat: P3032)

- $40 \mu \mathrm{g} / \mathrm{mL}$ de gentamicina (Sigma; cat: G1264)

- $1 \mathrm{mg} / \mathrm{mL}$ de colagenase (Sigma; cat: C9263)

- $5 \mu \mathrm{g} / \mathrm{mL}$ de Dnase 1 (Sigma; cat: DN25-100mg) 


\section{ANEXO E - DMEM digestão 2}

- DMEM (Invitrogen; cat: 11965-092)

- 1,1163mg/ mL $\mathrm{NaHCO}_{3}$ (Sigma; cat: S5761)

• 0,5846 mg/ mL L-glutamina (Sigma; cat: G8540)

e $1 \%(v / v)$ solução de aminoácidos não-essenciais (Sigma; cat: M7145)

e $100 \mathrm{UI} / \mathrm{mL}$ de penicilina (Sigma; cat: P3032)

- $40 \mu \mathrm{g} / \mathrm{mL}$ de gentamicina (Sigma; cat: G1264)

- 2,5 mg/ mL de tripsina (Sigma; cat: 27250-018)

- 0,82 mg/ mL EDTA (Sigma; cat: E5134-100g)

- $5 \mu \mathrm{g} / \mathrm{mL}$ de Dnase 1 (Sigma; cat: DN25-100mg) 


\section{ANEXO F - DMEM cultivo BSA}

- DMEM (Invitrogen; cat: 11965-092)

- 1,1163mg/ mL $\mathrm{NaHCO}_{3}$ (Sigma; cat: S5761)

e 0,5846 mg/ mL L-glutamina (Sigma; cat: G8540)

- $1 \%(v / v)$ solução de aminoácidos não-essenciais (Sigma; cat: M7145)

e $100 \mathrm{UI} / \mathrm{mL}$ de penicilina (Sigma; cat: P3032)

- $40 \mu \mathrm{g} / \mathrm{mL}$ de gentamicina (Sigma; cat: G1264)

- 60 mg/ mL BSA (Sigma; cat: 232-936-2) 